\title{
Building Roman Lycia: new inscriptions and monuments from the baths and peristyle buildings MI 1 and MI 2 at Oinoanda
}

\author{
N.P. Milner \\ University College London, UK \\ nicholas.milner@ucl.ac.uk
}

\begin{abstract}
A new building inscription (no. 1) from Oinoanda, found beside the baths building Ml 1 in 2011, dedicates the building to the Roman emperor Vespasian and his sons Titus and Domitian in AD 73. This article places the new find in the setting of the whole building complex, including the adjacent building $\mathrm{Ml}$ 2, which is likely to be a palaistra (wrestlingschool), though rebuilt over a century later. The inscription supplies new evidence for the date of the governor of LyciaPamphylia, Firmus. It also points to the existence of earlier baths, which is compared to other similar indications from elsewhere in Lycia. A second, but illegible, inscription was recorded in 2012, outside a doorway leading from building Ml 1 into the peristyle building Ml 2 (no. 2). A third inscription on a statue base in building Ml 2 was also recorded (no. 3 ), along with two other illegible statue-base inscriptions (nos 4 and 5). The article places them in the context of the inscribed monuments found earlier at the building complex (nos 6 and 7), which may have included the small building Ml 3, and discusses them in the light of the broader phenomenon of Julio-Claudian and Flavian baths buildings in the region, and the role of the provincial governors and procurators in overseeing such building projects. This allows us to draw some conclusions about the nature and impact of Roman rule in first-century Lycia, which brought within the reach of many Lycian cities piped water, Italian-style bathing and new, improved facilities for the regionally popular heavy athletic sports of boxing, wrestling and pankration (unarmed combat).
\end{abstract}

\section{Özet}

2011 yılında Oinoanda'da hamam yapısı MI 1'in yanında bulunan bir yapı üzerindeki yazıt (no. 1), yapının M.S. 73 yılında Roma İmparatoru Vespasian ve oğulları Titus ve Domitian'a adandığını göstermektedir. Bu makale, MI 1 yapısının yanında bulunan ve muhtemelen palaestra (güreş okulu) olan MI 2 yapısının yüzyıl kadar sonra tekrar inşa edilmesine karşın, bu yeni buluntuyu bütün yapı kompleksinin düzenlemesi içine yerleştirmektedir. Yazıt, LikyaPamphylia valisi Firmus için yeni bir tarih vermektedir. Aynı zamanda Likya'da başka yerlerde benzerleriyle karşılaştırılabilecek daha erken dönem hamamların varlığına işaret eder. İkinci yazıt okunaksız olup, MI 1 yapısından MI 2 peristil yapıya (no. 2) açılan kapının dışında 2012 yılında saptanmıştır. Üçüncü bir yazıt (no. 3) MI 2 yapısında bir heykel kaidesinde, iki diğer okunaksız heykel kaidesi yazıtıyla beraber (no. 4 ve 5) kaydedilmiştir. Makalede, bu yazıtlar belki de kü̧̈ük bir yapı olan MI 3 binasını da içine alan yapı kompleksinde daha önce bulunan yazıtlı anıtlar (no. 6 ve 7) bağlamında ele alınmakta ve bunlar bölgede bulunan Julio-Claudiuslar ve Flaviuslar dönemi hamam yapılarının daha geniş olgusu 1şı̆̆ında değerlendirilmekte ve bu tür inşaat projelerinin denetlenmesinde eyalet valilerinin ve procuratorlerin (temsilci) oynadığı rol tartı̧̧ılmaktadır. Bu sayede, pek çok Likya kentinin su borulu sisteme geçmesi, İtalyan tarzı hamamları ve bölgede popüler olan boks, güreş ve pankreas (silahsız dövüş) gibi ağır atletik sporlar için yeni ve geliştirilmiş tesisleri getiren Roma yönetiminin birinci yüzyılda Likya'daki doğası ve etkileri hakkında bazı sonuçlara ulaşabilmekteyiz. 


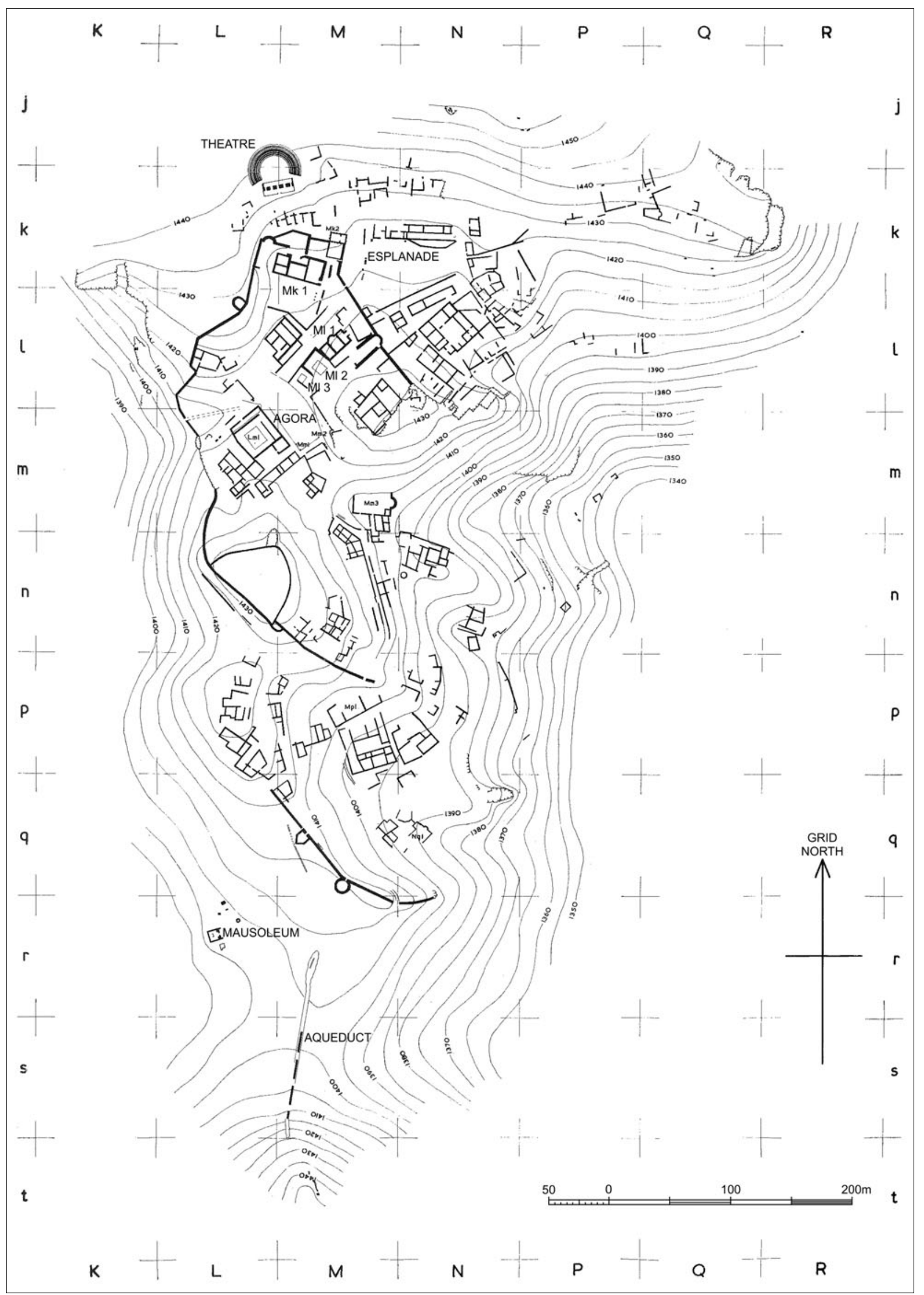

Fig. 1. British Institute at Ankara plan of Oinoanda (by J.J. Coulton). 
Tn the course of survey work at the Graeco-Roman city site of Oinoanda, in northern Lycia, by the German Archaeological Institute, Istanbul Department, in 2011, a fragment of a large, unpublished building inscription came to light, with a dedication to the emperor Vespasian and his two sons, Titus and Domitian, and consular dates for AD 73 (no. 1). It was found in rubble associated with building Ml 1 in the grid 'Ml' on the British Institute at
Ankara (BIAA) plan (figs 1,2), which is identified as a baths building. On the architectural results of the BIAA survey directed by the late Alan Hall between 1974 and 1983, see generally Coulton 1983: 1-20 and especially 89 on building Ml 1. The location of the inscription lies about half-way along the southern side of the northeastern street that linked the Roman agora to the 'Esplanade' or upper agora (figs 3, 4).

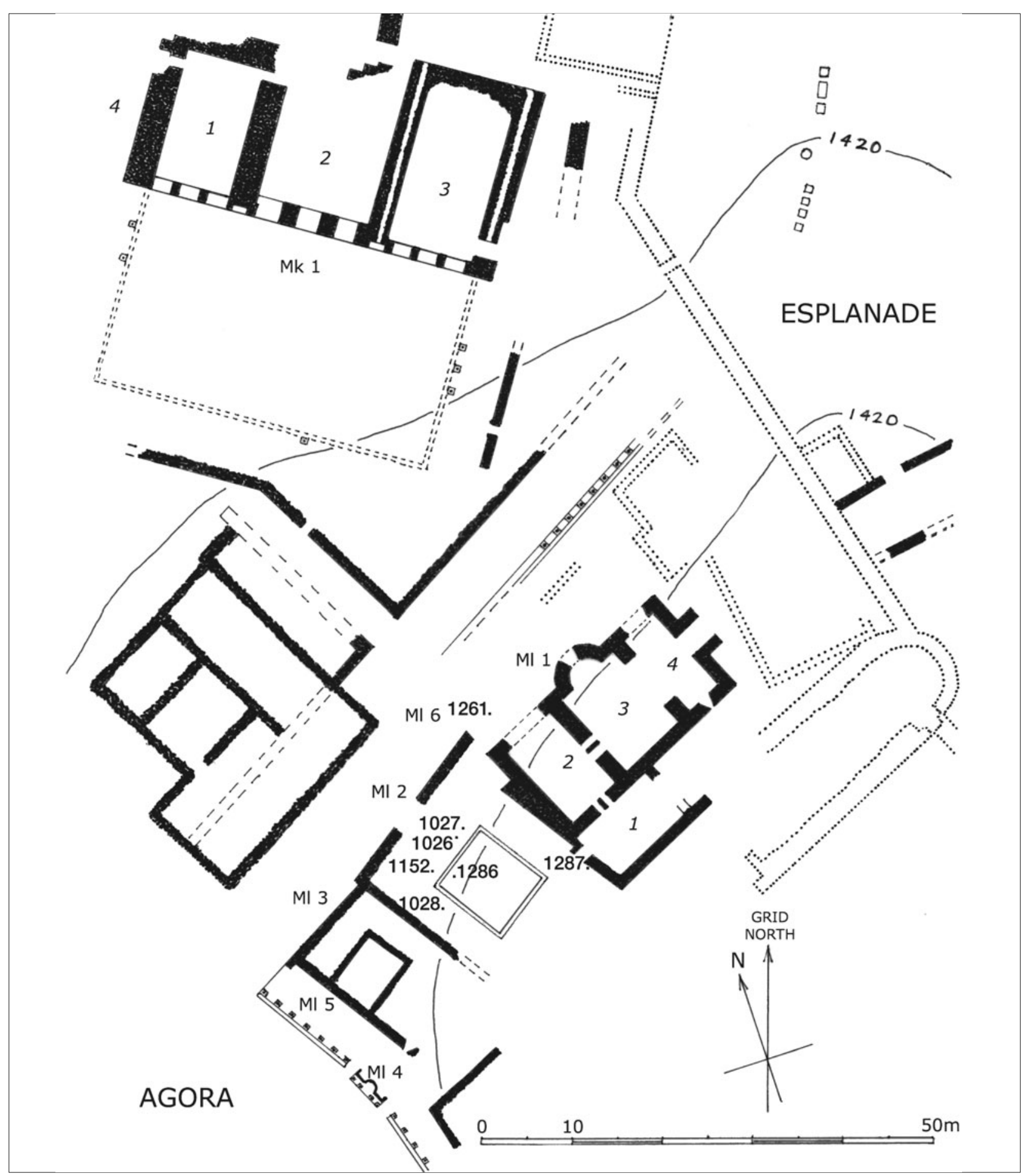

Fig. 2. Plan of the northeastern street area showing the two baths complexes, Ml 1-Ml 2 and Mk 1, partly restored (adapted by N.P. Milner from Ling 1981: 32; Coulton 1982: 46; 1986: 63; Farrington 1995: plan 6). 


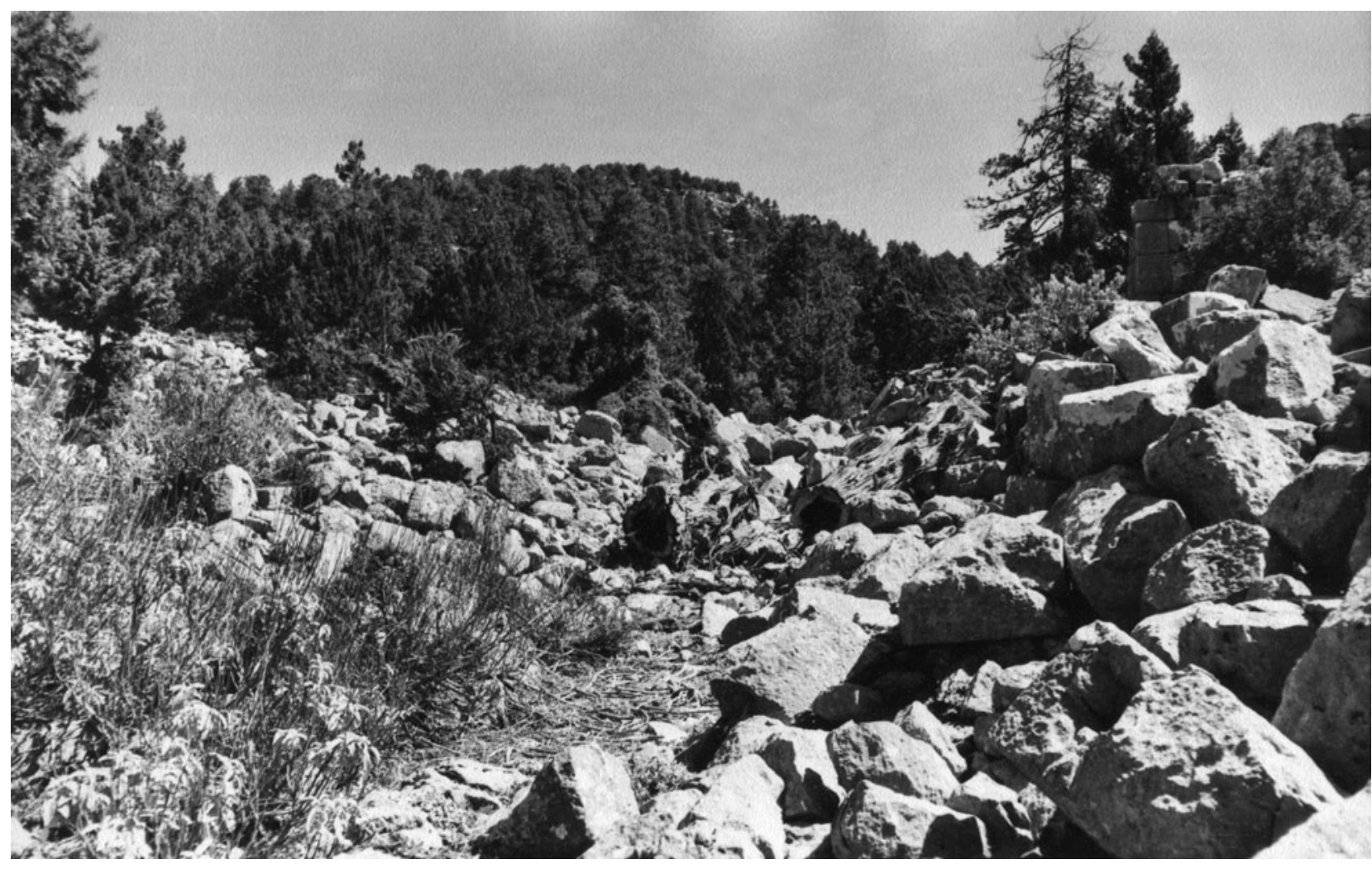

Fig. 3. The northeastern street, from the western end looking northeast (by A.S. Hall).

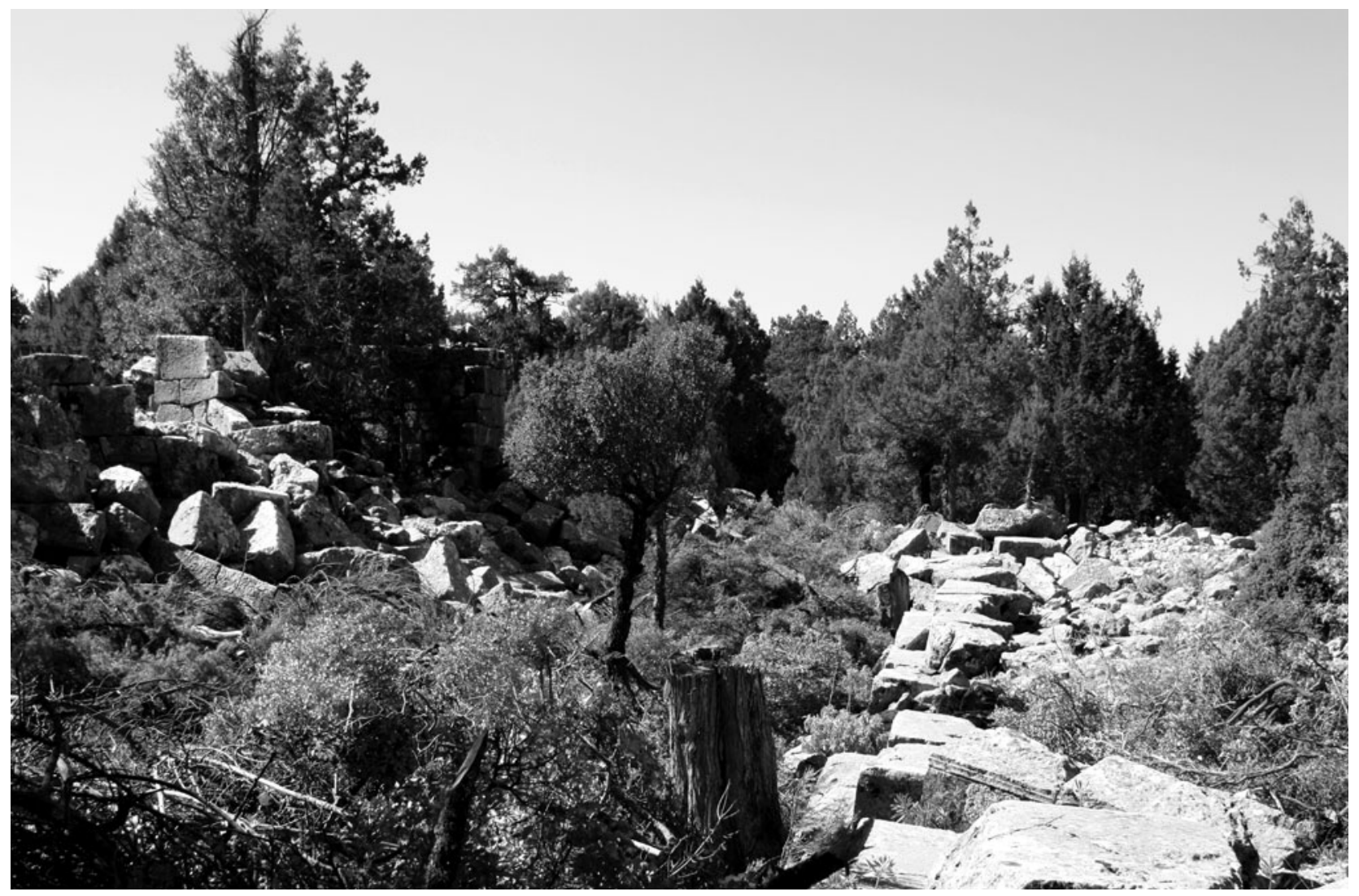

Fig. 4. The northeastern street, from the eastern end looking southwest. 


\section{Building inscription}

YÇ 1261. Northeastern street, southern side, ca 40m from the agora.

Found by In-Yong Song, a long limestone block, which has presumably fallen from the building, now stands diagonally on its left end, its inscribed face leaning slightly towards the ground, partly buried amid heavy debris on the southern side of the northeastern street, ca $4 \mathrm{~m}$ northeast of the northwestern corner of the western room ('room 2') of the ruined baths building Ml 1 (fig. 5). The block is Lshaped with the dressed left vertical face forming the front, and is worked flat on the lower and upper sides, and decorated with Ionic architrave grooves below, while the rear is roughly hollowed along its length (figs 6, 7). The front is adorned with a smoothed tabula within a plain, lightly-bevelled frame. Height $0.78 \mathrm{~m}$; width $1.2 \mathrm{~m}+$ (broken right); depth $0.28 \mathrm{~m}$ (above), $0.47 \mathrm{~m}$ (below); height of frame $0.08 \mathrm{~m}$. The block is weathered, and broken to right with a roughly vertical fracture, where the inscribed surface is further broken off at the bottom-right corner. The inscription is abraded by weather to right, but well preserved to left (fig. 8). The reconstructed inscription indicates that the missing part of the block is about oneand-a-half times as large as that discovered, and presumably lies nearby under the rubble. In its original state, the block would have measured ca $2.8 \mathrm{~m}$ long.

Inscription of nine lines in a framed tabula, height $0.62 \mathrm{~m}$ (plain frame width $8 \mathrm{~cm}$, probably decorated with an incised ansa at the middle of the left side, of which the inner end of the upper incision was seen, fig. 9), letters

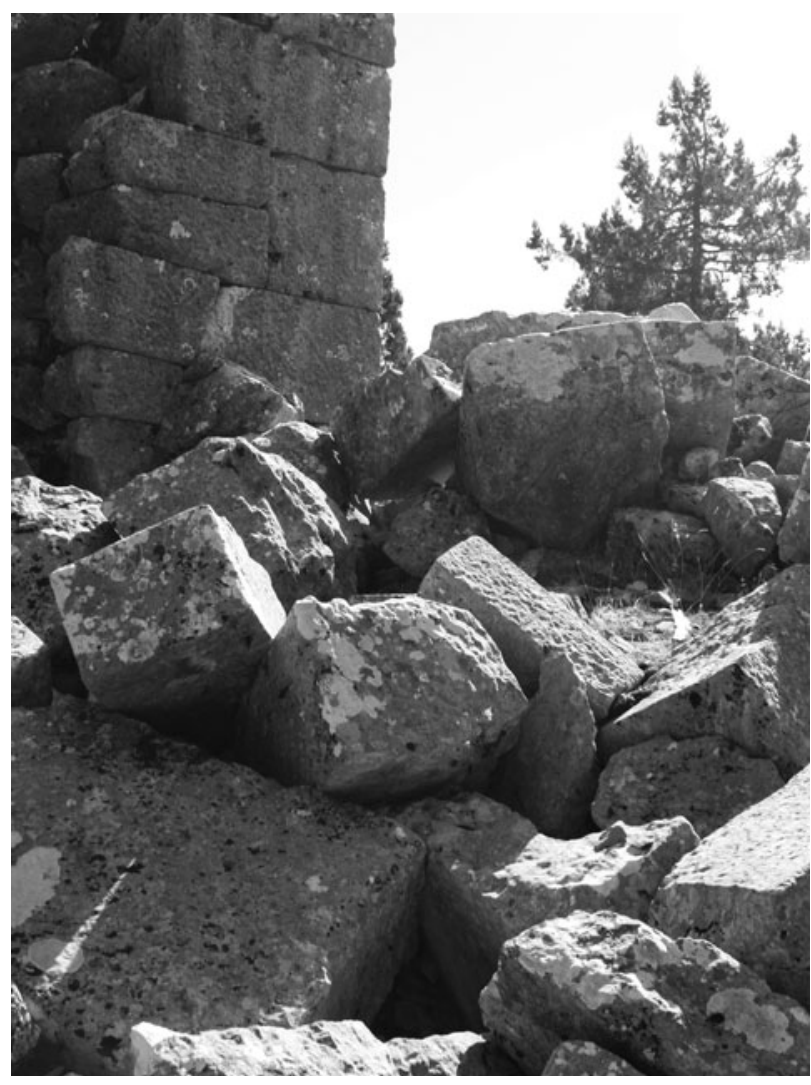

Fig. 6. YÇ 1261 context. The inscription is on the L-shaped block in the foreground.

$5 \mathrm{~cm}$ (line 1), $4-4.5 \mathrm{~cm}$ (the rest), apart from the first omicron in line 2 , which is $5 \mathrm{~cm}$, interlinear spacing $1.35 \mathrm{~cm}$, margin below line 9 is $9 \mathrm{~cm}$ (fig. 10).

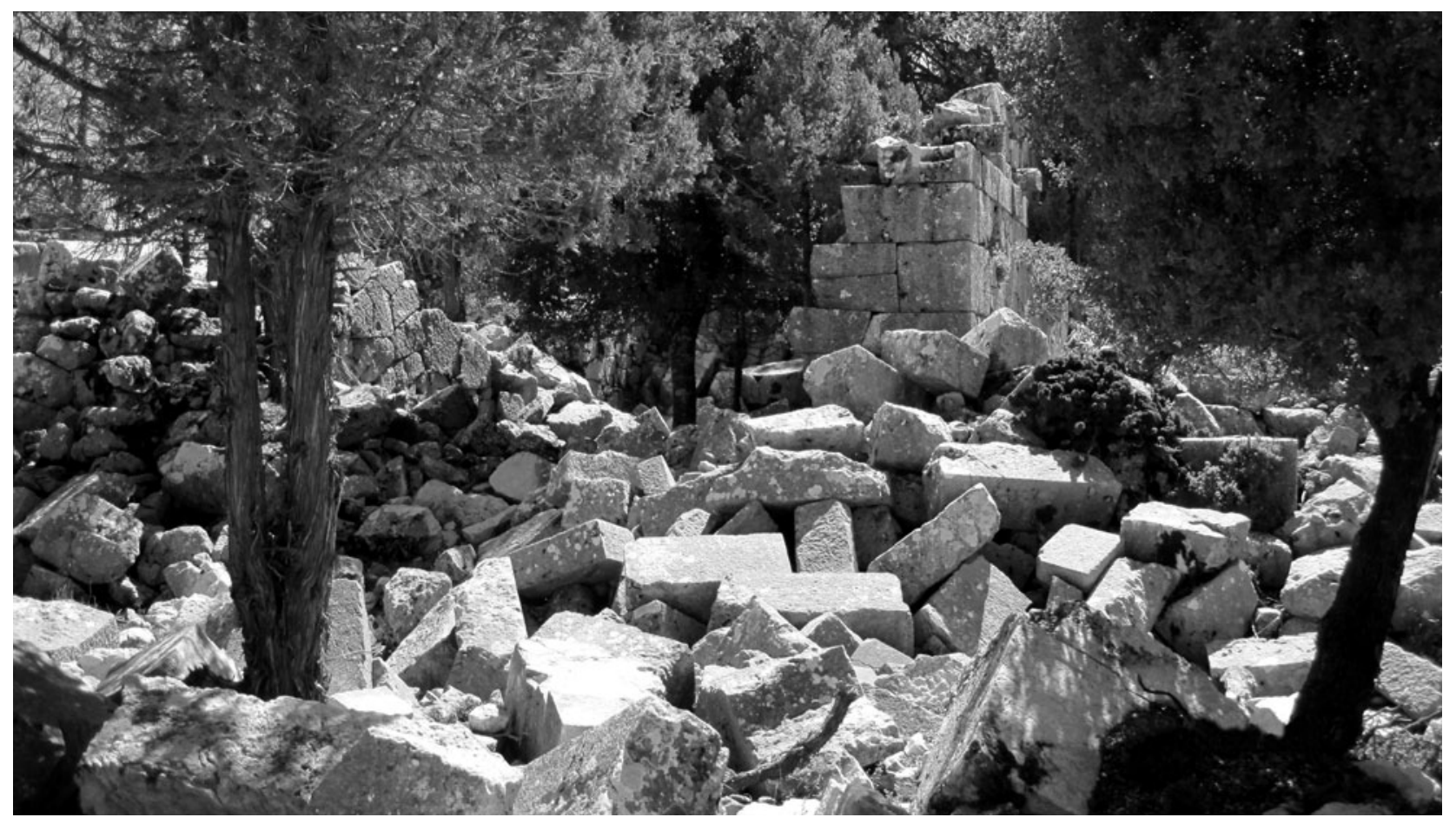

Fig. 5. Baths Ml 1 from the northeastern street. YÇ 1261 is located about the centre of the photo. 


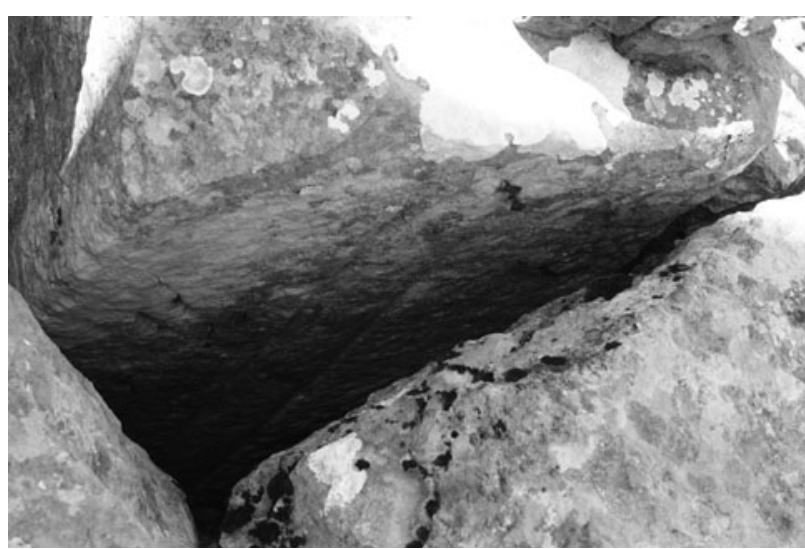

Fig. 7. YÇ 1261 underside.

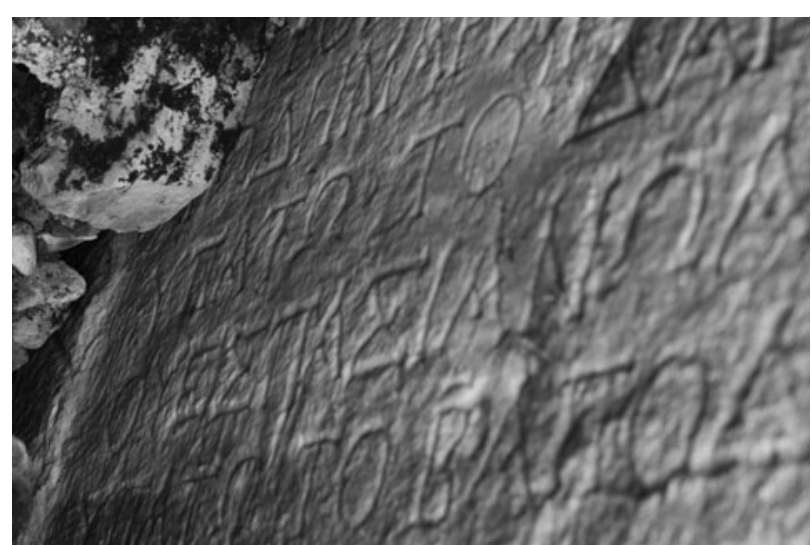

Fig. 9. YÇ 1261, left edge of tabula frame.

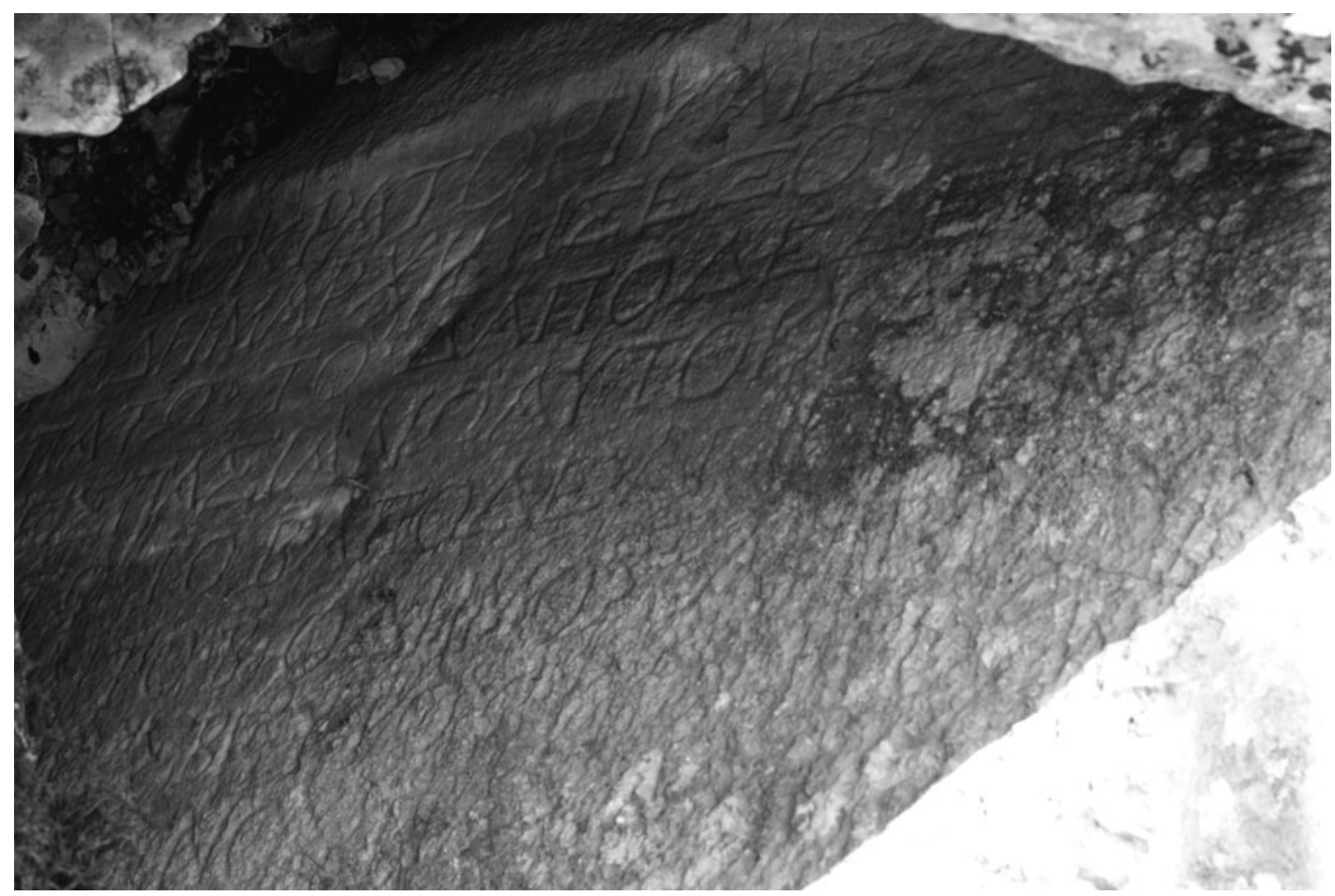

Fig. 8. YÇ 1261, lines $1-8$

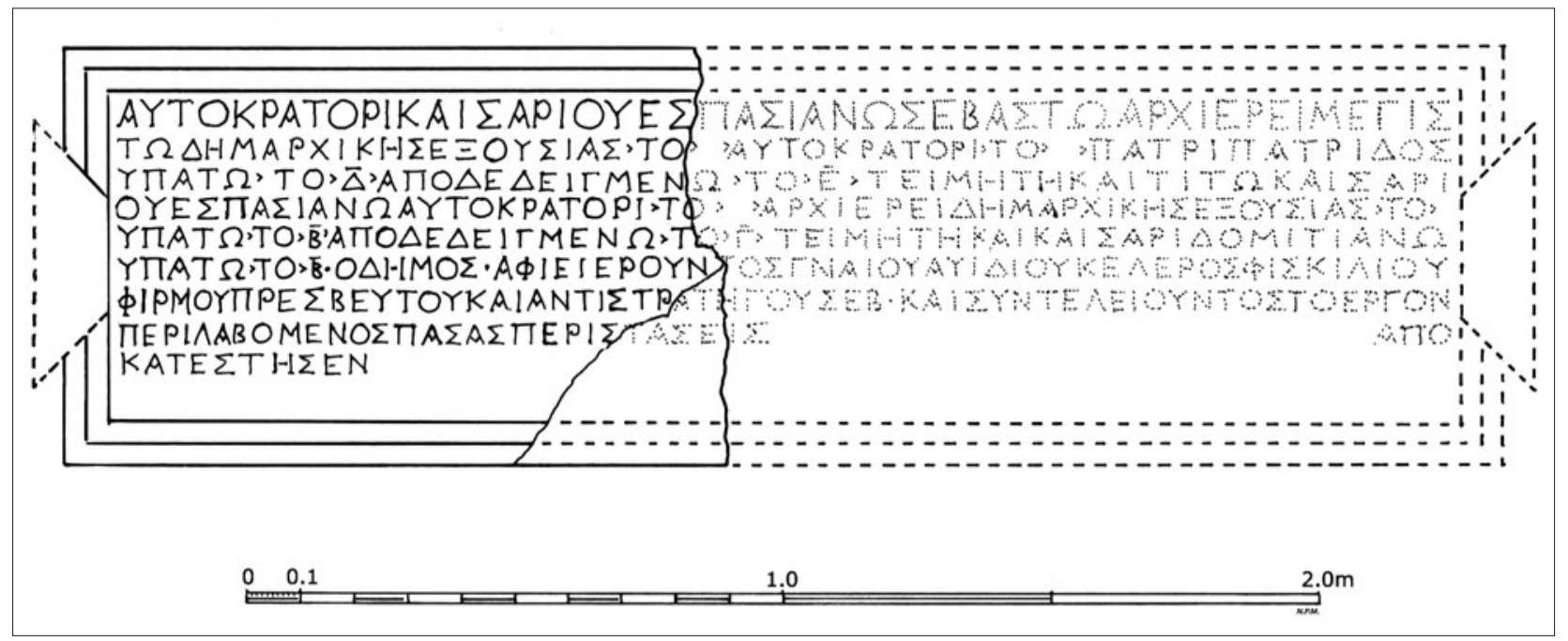

Fig. 10. YÇ 1261 drawing. 


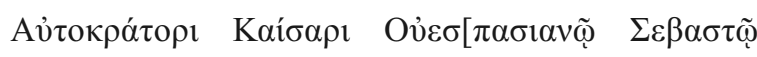

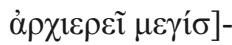

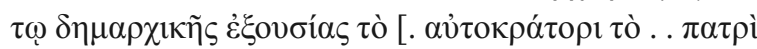
$\pi \alpha \tau \rho i ́ \delta o \varsigma]$

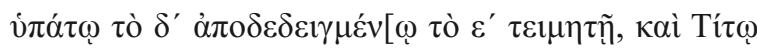

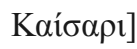

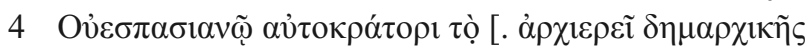

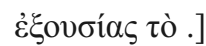

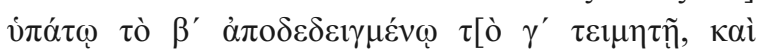

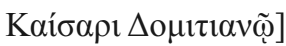

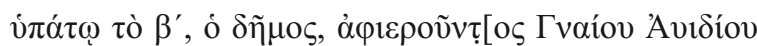

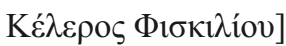

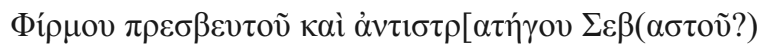

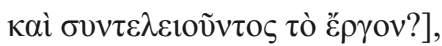

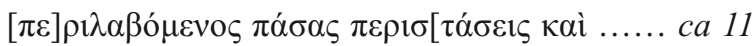

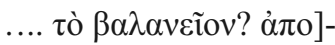

$[\kappa] \alpha \tau \varepsilon \varepsilon ́ \sigma \tau\rceil \sigma \varepsilon v$ vacat

To the emperor Caesar Ves[pasianus Augustus, chief ponti]ff, having tribunician power for the [...]nth time, [hailed as imperator for the ...nth time, father of the fatherland], consul for the fourth time, consuldesignate [for the fifth time, censor, and to Titus Caesar] Vespasianus, hailed as imperator for the [fifth] time, [pontiff, having tribunician power for the ...nth time], consul for the second time, consul-designate for the [third time, censor, and to Caesar Domitianus], consul for the second time, the People - [with Gnaeus Avidius Celer Fiscilius] Firmus, legatus Aug(usti) pro praetore, dedicating [and completing the work?] having caused to be included all peris[taseis and ...? re]stored [the baths?]

Letter-forms. Squared, monumental, with refined traces and apexes.

Date. Between March and 31st December AD 73, according to clear consular and consul-designate dates given for Vespasian, Titus and Domitian (Kienast 1996: 109, 112, 116). Vespasian was cos. IV cos. desig. $V$ from March 73 until 1st January 74; Titus was cos. II cos. desig. III from March 73 until 1st January 74; Domitian was cos. II in 73 and cos. desig. III from March 74.

Lines $1-6$. As the imperial titulature is there quite regular, the missing part in lines 1-2 appears 27-28 letters long, falling to as few as 25 letters in line 3 . In line 6 it appears to rise to 31 letters. The titles of Titus and Domitian comfortably fit the putative space, here supplemented after the model of a similar inscription from Balboura, dated AD 74 76 (SEG 28.1218 = AE 1978: 804), with the addition of $\kappa \alpha i$ in lines 3 and 5 . The numbers of the tribunician powers and imperatorial acclamations are not preserved, and there is no knowing that the Oinoandans would have been able to render them accurately in harmony with the consular dates. Their accuracy with regard to the latter, however, is much more probable (cf. Adak, Wilson 2012: 10-11).

Line 6. ó $\delta \tilde{\eta} \mu \mathrm{o}$, the People, but not the Council (boule) as well, are mentioned as having restored the building. The absence of the Council might mean that Oinoanda did not yet have a boule, as other small Lycian cities operated with a popular assembly (demos) and an executive committee of archons to prepare the assembly's business. But the silence in our inscription is not proof of the council's nonexistence (Rhodes, Lewis 1996: 475-78; Domingo Gygax 2001: 124). Although no earlier inscription from Oinoanda makes reference to a boule and one certainly existed by the reign of Hadrian (Wörrle 1988: 4, Demostheneia festival inscription, line 2), yet we can infer its probable existence already in the reign of Claudius. For a smaller city than Oinoanda, Gagai in southeastern Lycia, erected a statue-monument for the emperor Claudius, that was

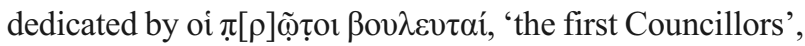
soon after $\mathrm{AD} 43$, in the context of what appears to be a general reform of the constitutions of the cities carried out on the initiative of the first Roman governor of the new province, Q. Veranius (Schuler, Zimmermann 2012: 61517 , with a new reading of SEG 50.1350; 51.1824 bis).

Lines 6-7. A genitive absolute in parenthesi, describing the role of the governor in dedicating and marking the completion of the building. Compare at the Patara baths (TAM 2.396; IGR 3.659; AE 2008: 1445; SEG 57.1671)

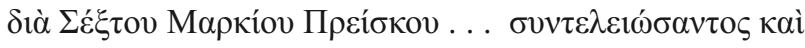

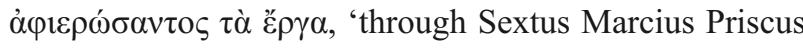
... having completed and dedicated the works', or a building inscription at Araxa (TAM 2.701 [corrected]): [ả]

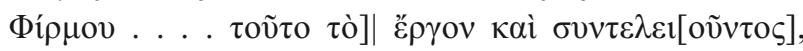
'Gnaeus Avidius Celer Fiscilius Firmus ... dedicating ... and completing [this] work'; the editors of TAM wrongly restore the latter participle in the aorist tense. Perhaps

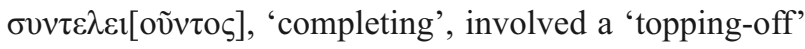
ceremony, in which the visiting dignitary was given the honour of symbolically putting the finishing touches to a building, a tradition which continues in the modern world. On the assumption of a similar line-length (56 letters) to the previous line, there is insufficient room for $\Sigma \varepsilon \beta(\alpha \sigma \tau$ ov $)$ after $\alpha \nu \tau \imath \sigma \tau \rho \alpha \tau \eta ́ \gamma o v$; but in fact the letters in the visible part of the line are more closely spaced, leading to a likely line-length of about 59 letters (see drawing, fig. 10).

Lines 8-9. A few words denoting the restored buildings or

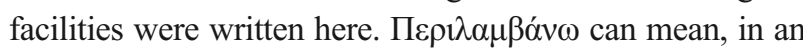
administrative context, 'include, take in' (see LSJ s.v.), and 
is here put unusually in the middle voice, where the nuance of $[\pi \varepsilon] \rho \imath \lambda \alpha \beta$ ó $\mu \varepsilon v o \varsigma$ might be, 'having caused to be included'; see Smyth 1956: 392 para. 1725, with reference to the administrative process whereby the People decreed psephismata linked to a contractual building specification. On ancient Greek building contracts (ergoniai) and specifications (syngraphai), compare for instance $I G 7.3073$ (Lebadeia) and Pitt 2014: 373-94. [ $\pi \varepsilon] \rho 1 \lambda \alpha \beta$ ó $\mu \varepsilon v o \varsigma$ seems to be a 'circumstantial' participle like its frequently found cognate $\lambda \alpha \beta \omega$ ' for a circumstance attendant on the action of the main verb; the precise force of the participle often needs to be interpreted from the context (see Smyth 1956: 459 para. 2068a). It seems here to be used as an alternative to oúv + dative, meaning 'included in the sum total', which is found in the baths inscriptions at Patara (TAM 2.396; SEG 57.1671) and on which compare Smyth 1956: 386 para. 1696a.

The suggested substitution of the participle + accusative for $\sigma u ́ v+$ dative is prominently placed between the

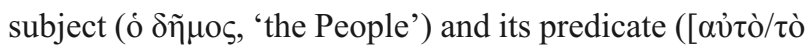
$\beta \alpha \lambda \alpha v \varepsilon i ̃ o v \alpha \pi \circ \mid \kappa] \alpha \tau \varepsilon \dot{\varepsilon} \sigma \tau \eta \sigma \varepsilon v$, 'restored it/the baths') and seems to balance the lengthy genitive absolute clause in parenthesi referring to the actions of the governor. As well as stressing the importance of the support of the governor, the interwoven sentence structure delicately allows the People (o $\delta \tilde{\eta} \mu \varsigma_{\varsigma}$ ) to suggest their priority, as well as the complementarity of their actions in carrying out the works, the extent of which is indicated by reference to some of the scheme's more notable features, as 'including all $\pi \varepsilon \rho ı \sigma[\tau \alpha \sigma \varepsilon \varepsilon ı$... ] (i.e. in the works)'.

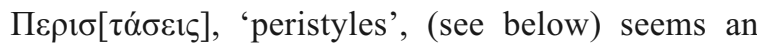
inevitable supplement: no other plausible feminine word beginning $\pi \varepsilon \rho 1 \sigma-$ can be supplied. The use of $\pi \alpha$ á $\sigma \varsigma$ $\pi \varepsilon \rho ı \sigma[\tau \alpha ́ \sigma \varepsilon \iota \varsigma]$ without a definite article is probably best explained as an abbreviated style of writing, to which the epigraphic form lends itself, being equivalent to $\pi \alpha ́ \sigma \alpha \varsigma \tau \grave{\alpha} \varsigma$

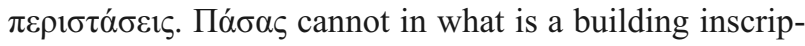
tion, not a philosophical treatise, mean 'all conceivable', as if it were used attributively (on which, see Smyth 1956: 296 para. 1174).

An anonymous reviewer has suggested an alternative construction that would supply a definite article to $\pi \alpha ́ \sigma \alpha \varsigma$,

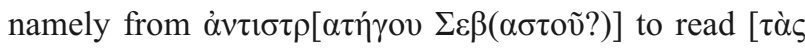

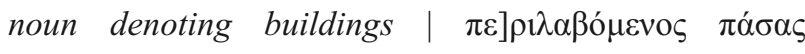

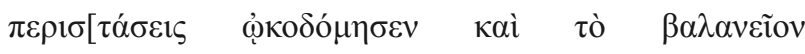
$\dot{\alpha} \pi \mathrm{o} \mid \kappa] \alpha \tau \varepsilon \dot{\varepsilon} \sigma \tau \eta \sigma \varepsilon v$, 'having included/ fenced in all the ... (reference to other buildings) built colonnades and restored the baths'. One might on similar lines suggest [ $\tau$ à ৎ noun

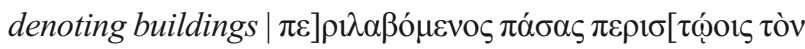

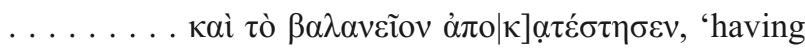
enclosed all the ... with peristyles, restored the ... (building)

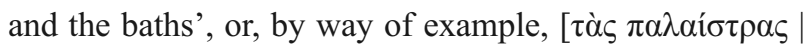

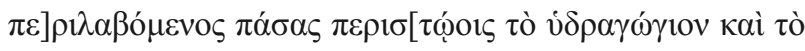
$\beta \alpha \lambda \alpha v \varepsilon \tilde{\tau} \sigma \mathrm{\alpha} \pi \mathrm{\pi} \mid \kappa] \alpha \tau \varepsilon \dot{\varepsilon} \sigma \tau\rceil \sigma \varepsilon v$, 'having enclosed all the palais- tras with peristyles, restored the aqueduct and the baths'. Such a context with $\pi \varepsilon \rho \imath \lambda \alpha \beta$ ó $\mu \varepsilon v o \varsigma$ would find some support in Dionysius of Halicarnassus Antiquitates

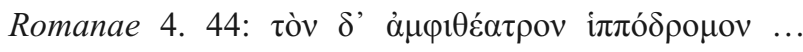

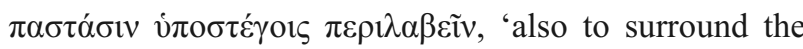
Circus ... with covered porticoes'. To fit [ $\tau$ ì $\varsigma$ noun denoting buildings] into line 7, however, any such alternative construction would require severing the second leg of the

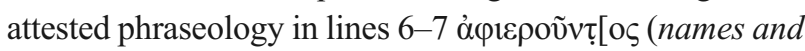

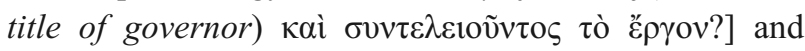

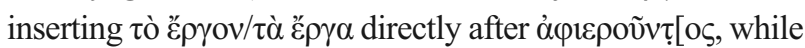
abbreviating the praenomen of Firmus. The rest of this commentary will assume the first construction.

$\Pi \varepsilon \rho 1 \sigma \tau \alpha \dot{\sigma} \sigma ı \varsigma \varsigma$ was another term for peristyles ( $\pi \varepsilon \rho i ́ \sigma \tau \nu \lambda \alpha$ ), whether the colonnades themselves or the courts enclosed within colonnades (see Orlandos, Travlos 1986 s.v.; Hellmann 1992: 335 s.v. $\pi \varepsilon \rho i ́ \sigma \tau \nu \lambda o \varsigma)$. Other baths and gymnasium inscriptions refer to 'stoas', i.e. porticoes, and 'exedras', either meaning 'a room set off a peristyle' (see Farrington 1995: 69) or else merely 'an apse' (see Reitzenstein 2014: 561-63 with evidence of exedras in baths at Tlos, Myra and Telmessos). Take, for example, IGR $3.690+1523=I L S 8796$ (Simena, Lycia,

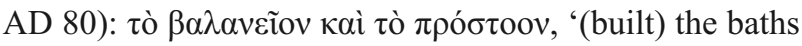
and the portico'; TAM 2.905 XIX A/B (with reference to

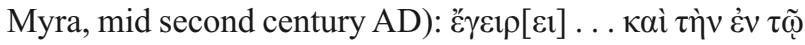

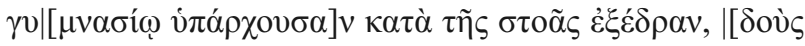

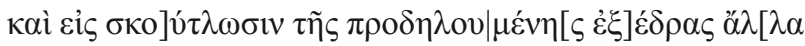
$(\delta \eta v$.$) - ], 'he built ... also the exedra in the stoa of the$ gymnasium, giving for the marble veneering of the aforesaid exedra [so many (denarii)]'; TAM 2.578 (Tlos,

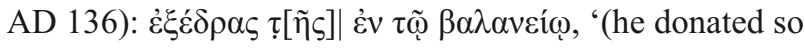
many denarii for the construction also) of the exedra in the

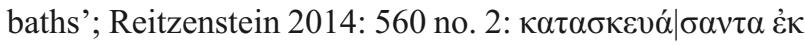

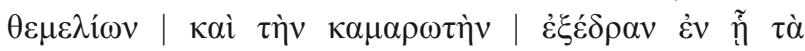
$\dot{\alpha} \pi \mathrm{o} \mid \delta v \tau \eta \dot{p} \rho \iota$, 'having built from the foundations also the vaulted exedra in which is the changing-room'; CIL $12.4342=I L S 5685$ (Colonia Narbo Martius, AD 145): ther[mas incendio] consumptas cum port[icibus et ... ] et basilicas et omni [apparatu? pecunia] sua re[stituit], 'restored the baths after they had been destroyed by fire, with their porticoes and ... and the basilicas and in all [magnificence?], with his [money]'. Epictetus Encheiridion 24 refers to stoas and baths as usual foundations of civic benefactors; compare IGR 3.704 IIA.1 (Kyaneai, with reference to Myra, mid second century

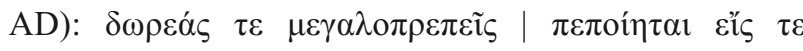

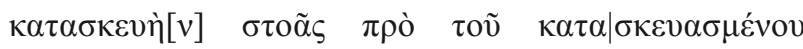

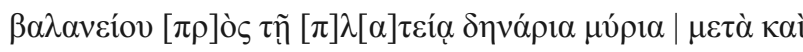
$\tau \tilde{\eta} \varsigma \theta[v] \gamma \alpha \tau \rho \grave{\varsigma} \varsigma \alpha \dot{\tau o v} \Lambda v[\kappa i ́] \alpha \varsigma$, 'and he has made magnificent gifts and for the construction of a stoa in front of the baths that have been built facing the street, 10,000 denarii, with his daughter Lykia ...'. The plans for the baths at 
Prusa adopted by Pliny (Epistulae 10.70-71: ego, si permiseris, cogito ..., 'what I have in mind, with your permission, is ...') included in a separate part of the site an exedra and porticoes, dedicated to Trajan, presumably to create an enclosure for a palaistra; Trajan was prepared to reject the enclosure dedicated to himself if it meant erasing a temple to Claudius that had been built on the spot, albeit now totally collapsed, an important detail about which he accuses Pliny of not being clear.

Another meaning of peristaseis may perhaps be briefly considered here: what the lexicon calls, 'free spaces round a building' (LSJ s.v.), and which is more accurately translated, given their size, purpose and design, as 'drainagecorridors'; so, SEG 45.1674. Such peristaseis are most clearly attested in the second century BC 'astynomic law' from Pergamon $(S E G 13.521=$ OGIS 483), where they were covered channels built with a retaining wall and stone slab covers below ground level around walls of buildings on a steeply sloping site, to protect the buildings from water-ingress (see Hennig 1995: 258). The water run-off from higher ground was collected in these substantial subterranean corridors around the walls and carried away downhill safely past the building. Excavations at Pergamon have identified such drainage-corridors around the northern and western sides of the upper gymnasium, which were built into the hillside (Schazmann 1923: 64), and other similar structures have been identified at Sagalassos in a comparable hillside location (Waelkens, Poblome 1995: 60).

The only hill above building M1 1 is that immediately to the south-southeast, called the East Hill in Stenton, Coulton 1986: 32-33, potentially the site of the end tank for the aqueduct, and otherwise known as 'Martin's Hill' after Martin Ferguson Smith's discoveries of blocks of the Diogenes philosophical inscription in that area. It is conceivable that parallel drainage-corridors might have been built around any walls threatened with water-ingress on this side, but, as it happens, building Ml 1 stands almost on the flat valley floor, and as such would not appear to need that kind of protection. Also, any such structures would have been almost entirely invisible and taken for granted by people using the baths; they are not elsewhere singled out for mention in a building inscription, and are unlikely to be referred to in ours even if they existed.

After $\pi \varepsilon \rho 1 \sigma[\tau \alpha ́ \sigma \varepsilon 1 \varsigma]$ some other perhaps plural word, which does not have to be feminine (see Smyth 1956: 274 para. 1030), referring to another notable feature of the

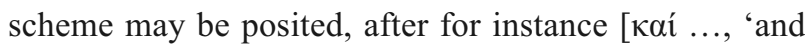
...']. For the line to be of similar length to lines 6 and 7 ,

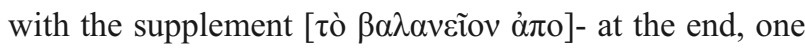

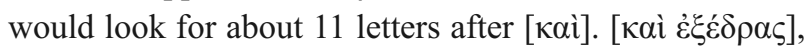

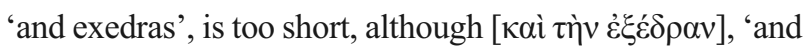
the exedra', would about fit; there is one obvious exedra

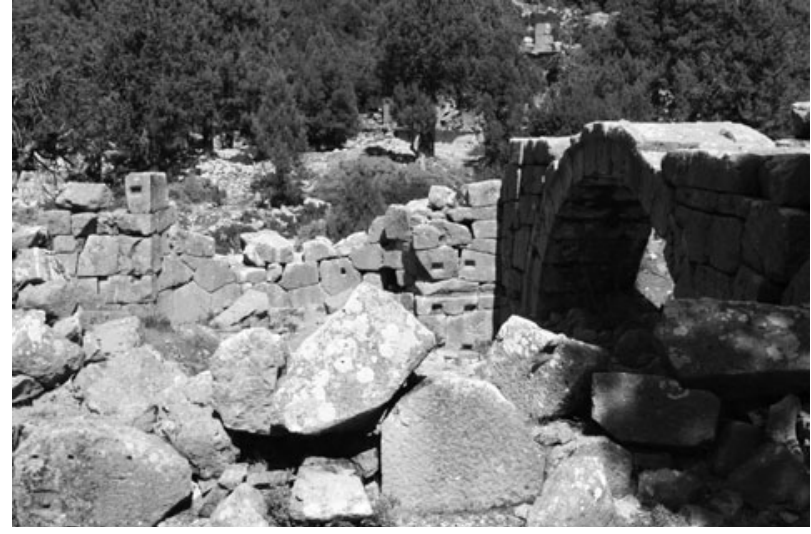

Fig. 11. Ml 1, from the eastern entrance to room 1 looking north into room 3.

built out from the northern side of room 3 of Ml 1 (fig. 11).

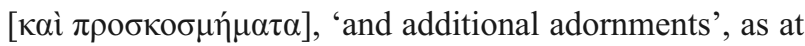
Patara (TAM 2.396; SEG 57.1671), a vague term like the

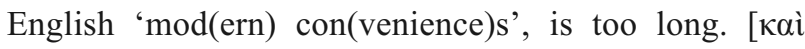

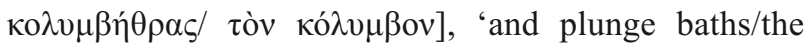
plunge pool', as again at Patara (TAM 2.396; SEG 57.1671)

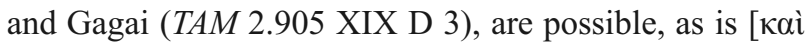

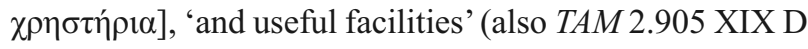
3 ). For traces of a possible plunge pool in rooms 3 and 4 of building Ml 1 at Oinoanda, see Farrington 1995: 155.

One could also end the phrase at $\pi \varepsilon \rho 1 \sigma[\tau \alpha \dot{\sigma} \sigma \varepsilon 1 \zeta]$ and introduce a new modification of the main verb such as [ $\dot{\varepsilon} \kappa$

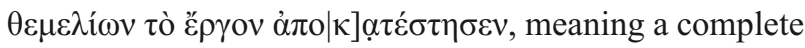
rebuild of the 'work', meaning baths and peristyles, 'from

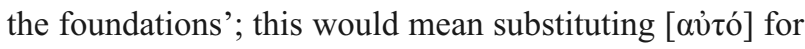

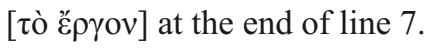

Line 9. 'ं $\pi \mathrm{o} \mid \kappa \alpha \tau \varepsilon \dot{\varepsilon} \sigma \tau \eta \sigma \varepsilon \nu$, 'restored, reinstated', is the main verb, whose subject is ò $\delta \tilde{\eta} \mu \mathrm{o}$, 'the People', and whose direct object it seems necessary to supply in [ $\tau$ ò

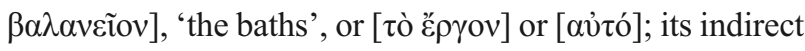

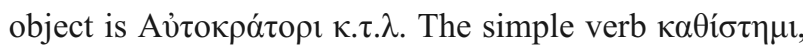
'set up, erect', is not used in building inscriptions (see Orlandos, Travlos 1986: s.v.). We must then conclude that public baths at Oinoanda existed before the Flavians, as at Patara and Olympos (see further below).

\section{Inscriptions from the peristyle court building MI 2}

To provide a further setting for the baths inscription presented above, all the identified inscriptions in the adjacent building Ml 2 are listed in this section. They show that there was another building inscription, and the nature of the statues erected on the inscribed bases around the peristyle court was, in the three cases where we can read the inscription, agonistic, i.e., in honour of victorious athletes, two of them boys. In the two cases where the event is preserved, the athletes were victors in boxing and wrestling. 


\section{Building inscription}

YÇ 1287. Peristyle court building Ml 2.

Found by In-Yong Song and Nicholas Milner in 2012, an in situ limestone block, forming the second course above ground level of a wall and the right side of a doorway leading from the eastern corner of the peristyle court, $\mathrm{Ml} 2$, into room 1 of the Flavian baths building, Ml 1 (figs $2,12,13,14)$. The block, which is now broken in two, was originally shaped with a nearly centred rectangular limb projecting to the rear at right angles into the thickness of the wall. The left end of the block has broken off roughly in line with the left side of the rear projection.

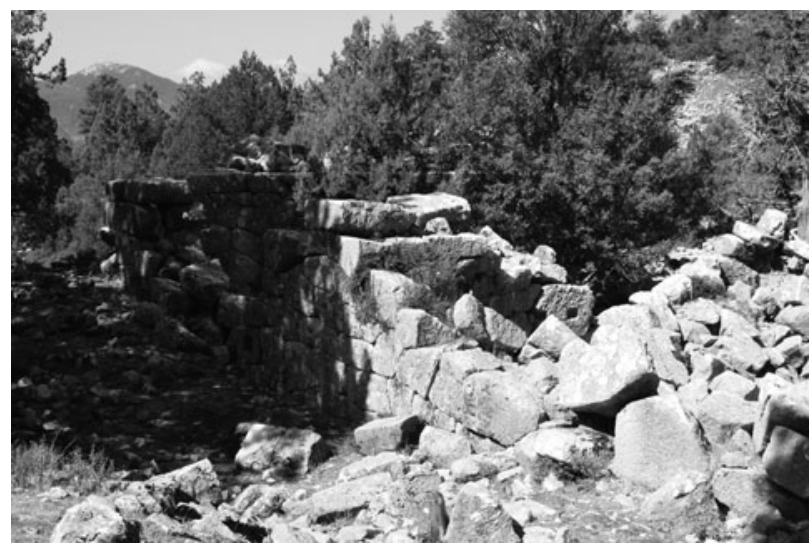

Fig. 12. Ml 1, from the eastern entrance to room 1 looking west.
Its long front surface was dressed with a tabula ansata that was placed in the wall so as to face directly down the southern range of Ml 2. The alignment of the wall to the right of the doorway thus matches that of the rectangular ranges of $\mathrm{Ml}$ 2, and diverges in a southerly rotation from the western wall of room 2 of Ml 1 and the northern and southern walls of room 1 , which it cuts off diagonally. The right piece of the block measures: height $0.57 \mathrm{~m}$; width $1.47 \mathrm{~m}$ (broken left); depth 0.95 at the thickest point. There is what appears to be a boss on the lower part of the outer face, towards the left. The tabula ansata is preserved only in its right half; the left has been abraded away by weather

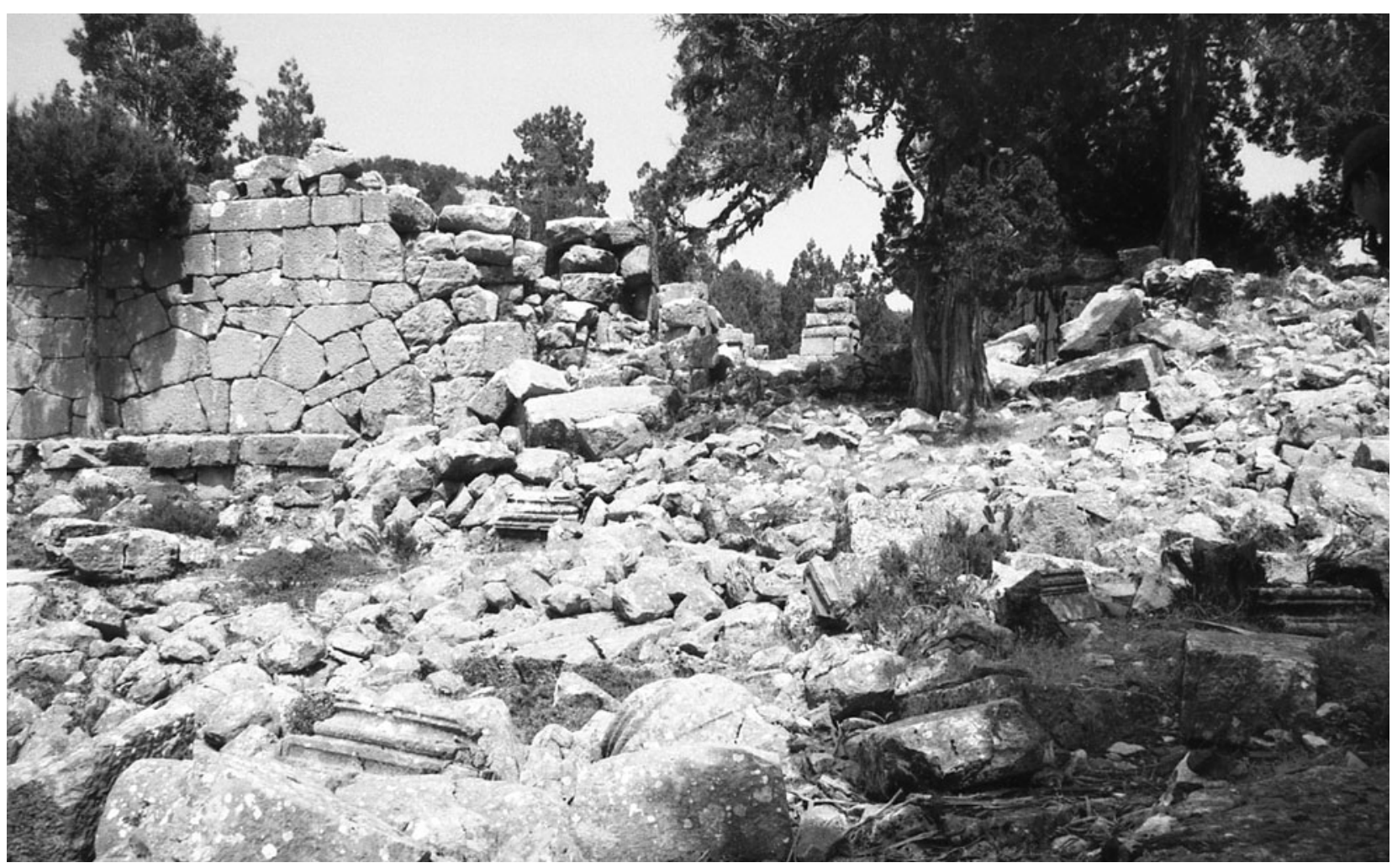

Fig. 14. YÇ 1287 context (behind tree), eastern corner of Ml 2, looking towards room 1 of Ml 1 . 


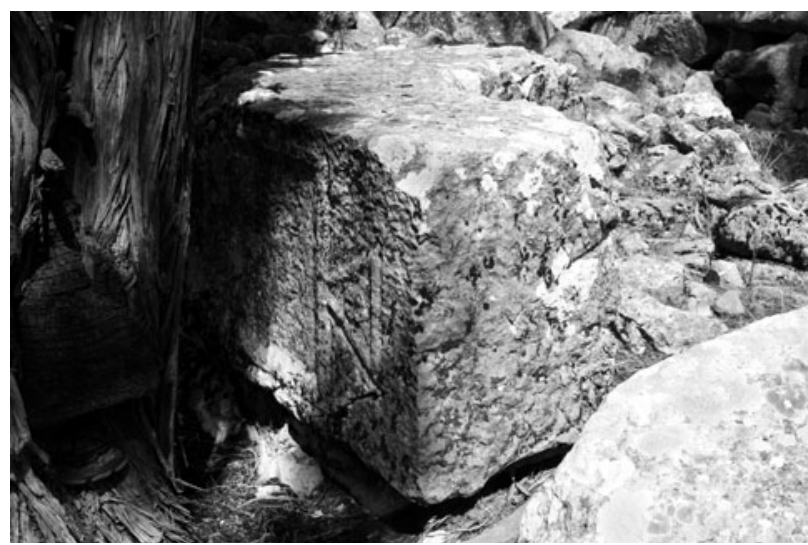

Fig. 15. YÇ 1287, right side and top.

before the stone breaks off: height $0.47 \mathrm{~m}$ (including frame); height of inscribed field $0.37 \mathrm{~m}$. The right ansa measures: height $0.1 \mathrm{~m}$, rising to $0.28 \mathrm{~m}$; width $0.17 \mathrm{~m}$. A disc in the ansa has a diameter of $0.06 \mathrm{~m}$. The inscription, whose traces suggest about 12 lines of perhaps $2.5-3 \mathrm{~cm}-$ high letters, is completely illegible (figs 15,16 ). The alignment of the block, from both the point of view of the inscription being set up to face down the southeastern wing of the peristyle and the presumed reorientation of the western wall of room 1 of Ml 1 in which it was constructed, suggests that it should be connected with the rebuilding of the peristyle court Ml 2 in its later more southerly orientation, thus in the late second or third century AD.

\section{Statue base for Aurelius (H)er ..., boy...}

YÇ 1286. Peristyle court building Ml 2.

Found by Nikolaus Koch in 2012. Fragment of limestone base, lying amid debris in the western corner of the courtyard beside the stylobate (fig. 17). Height ca $0.78 \mathrm{~m}$ (broken above and below); width $0.36 \mathrm{~m}+$ (broken partly left and right); depth $0.68 \mathrm{~m}$. The inscribed face measures: height ca $0.3 \mathrm{~m}$; width ca $0.36 \mathrm{~m}$. The block has some complete surfaces preserved, at the lower left side, the front generally and at the rear, upper part. The inscription is much abraded by weather to right and better preserved only close to left. Inscription of four lines surviving, letters $2 \mathrm{~cm}$, interlinear spacing $1 \mathrm{~cm}$. Letterforms: squared, omicron full-sized, sigma four-barred with horizontal top and bottom hastae, omega with in-turned volutes and no 'feet' below (figs 18, 19).

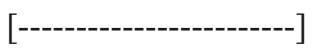

Ạủ $\rho$ EP [-------------]

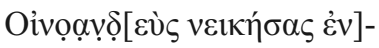

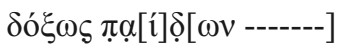

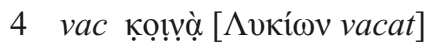
vacat
}

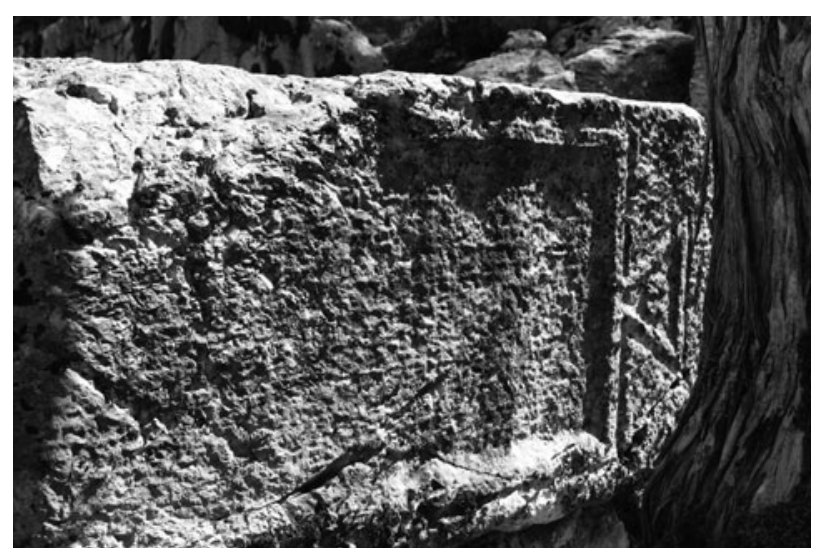

Fig. 16. YÇ 1287, tabula.

... Aur(elius) Her[----- son of ------], citizen of Oinoanda, having [won] with honour the boys' [--------] in the games open to all [Lycians].

Date. First half of the third century AD, after AD 212.

Line 1. Because of a chip off the corner of the stone, only the end of the right hasta of alpha is preserved. The abbreviation for Aurelius dates the inscription to after the constitutio Antoniniana of $\mathrm{AD} 212$. The name is largely missing, but appears to have begun $\mathrm{Er} / \mathrm{Her}-$, and so a Hermes theophoric such as the regionally extremely popular name Hermaios is quite likely.

Line 3. $\pi \alpha[i] \delta[\omega v]$, 'boys', will have been followed by the name of the event, such as $\pi \alpha \dot{\lambda} \eta \eta v, \pi \alpha v \kappa \rho \alpha ́ \tau 1 o v$ or $\pi v \gamma \mu \eta$, 'wrestling', 'pankration, unarmed combat', 'boxing'. All were locally popular, but, more especially, only these events were commemorated for victors, in the men's and boys' classes, in the quadrennial festival known as the Euaresteia after its founder, the local schoolmaster Iulius Lucius Pilius Euarestos (Hall, Milner 1994: 45).

Several lines will have preceded our line 1, containing the name of the agonothetes, the name and number of the games, and the name of the founder, as for instance in $S E G$ 44.1165. The other two inscribed bases lying in the same court are for victors in the boys' boxing and the men's wrestling, who won in celebrations of the Euaresteia, both of them post $A D 212$ in date, and one of them from the fourth celebration, dated probably to AD 235-238 (Hall, Milner 1994: 29-30; SEG 44.1178, 1179). The only bases with кoıvò $\Lambda v \kappa i ́ \omega v$, 'open to all Lycians', on them at Oinoanda are from the Euaresteia, which was apparently the first pan-Lycian athletics festival at Oinoanda, a status that was stressed on the victors' bases. The new fragment is therefore with some probability to be attributed to the Euaresteia. 


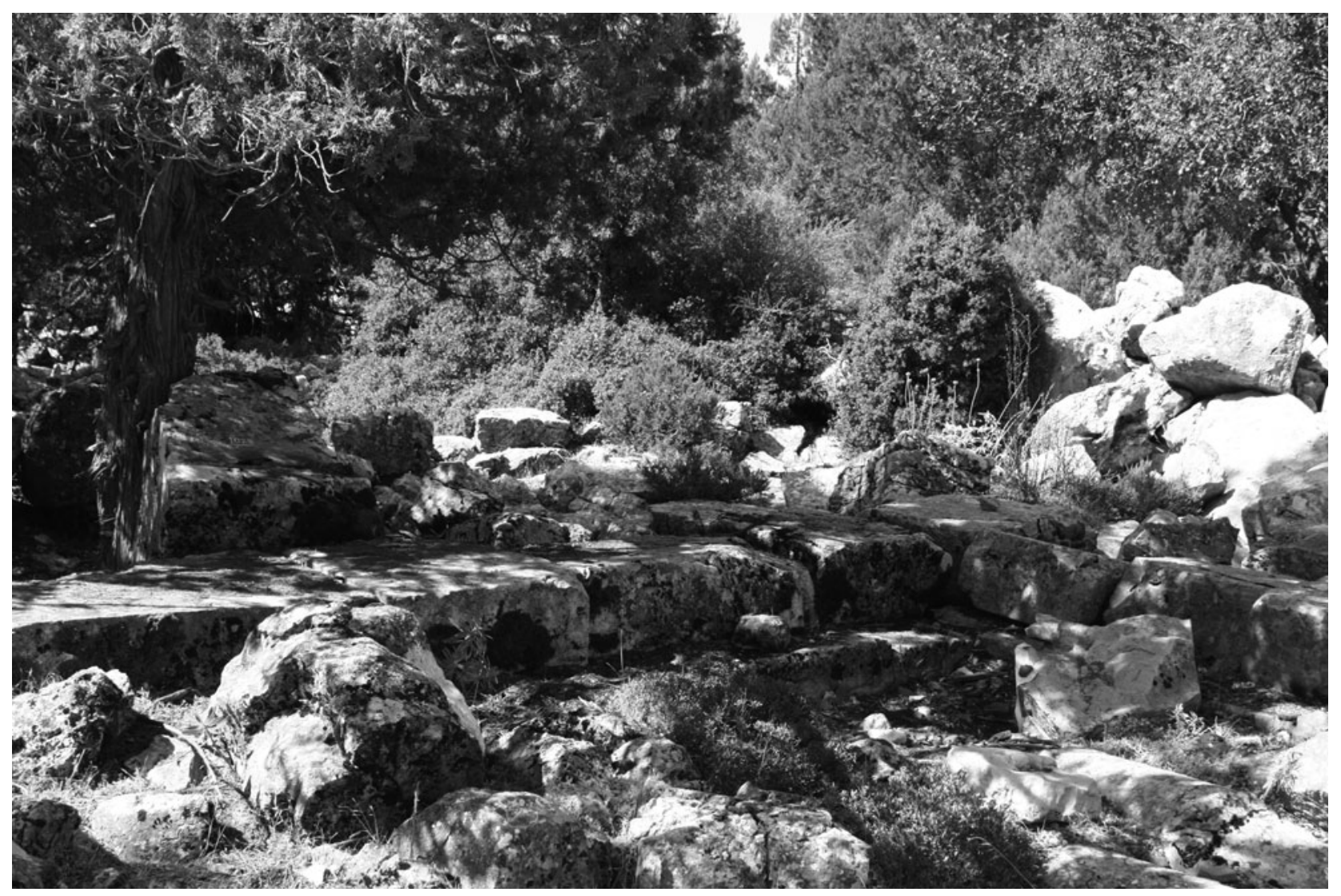

Fig. 17. YÇ 1286 and 1028 context, western corner of Ml 2.

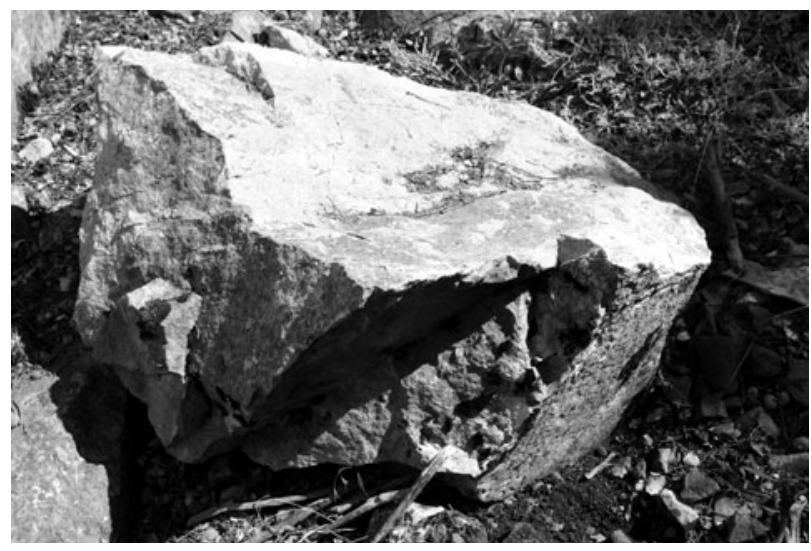

Fig. 18. YÇ 1286, broken front, right and upper surfaces.

\section{Statue base for anonymous}

YÇ 1026. Peristyle court Ml 2.

A limestone statue base, lying in heavy rubble beside YÇ 1027, 2m west of the northern corner of the central court of building Ml 2, in the peristyle walk (figs 20, 21). Height $1.39 \mathrm{~m}$; width $0.54 \mathrm{~m}$ (foot), $0.48 \mathrm{~m}$ (shaft); thickness $0.71 \mathrm{~m}$ (foot), $0.51 \mathrm{~m}$ (shaft) (A.S. Hall, notebook). The base is well-preserved in front, damaged at the rear top and below left front, but its inscription of perhaps 13 or 14 lines (A.S. Hall, notebook) is illegible. It dates to the first half of the third century AD, as the base is of the same type and design as YÇ 1027 and 1028 (nos 6 and 7).

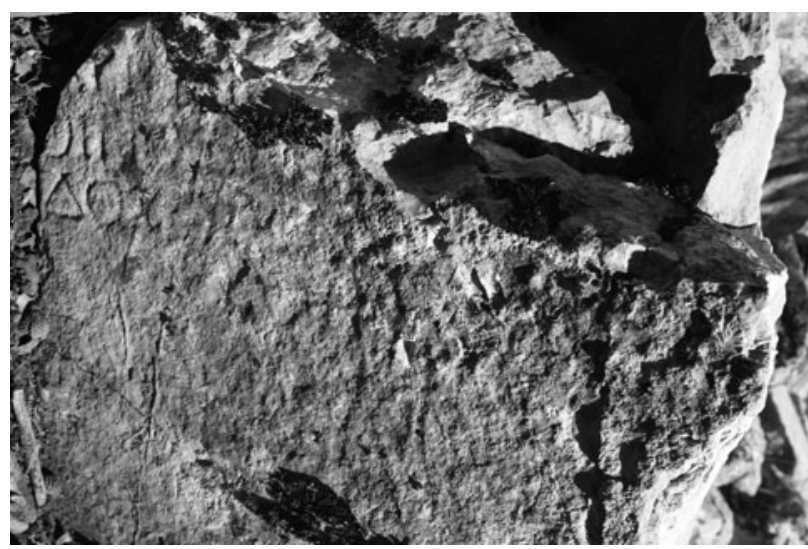

Fig. 19. YÇ 1286 detail.

\section{Statue base for anonymous}

YÇ $1152=$ WS 113. Peristyle court Ml 2.

A limestone statue base broken into three pieces, lying near YÇ 1028, at the western corner of the peristyle court, in the northern stylobate (figs 22, 23, 24). The top of the base had a circular hole in it for statue fixing (fig. 24). Height $0.3 \mathrm{~m}$ (foot), $1.02 \mathrm{~m}$ (shaft), $0.28 \mathrm{~m}$ (cap); width $0.67 \mathrm{~m}+$ (cap), $0.55 \mathrm{~m}+$ (shaft); thickness $0.67 \mathrm{~m}$ (shaft). R. Heberdey's notes, taken from his examination of the stones in June 1902 and filed under inventory number WS 113, read as follows: 'Bei voriger [= YÇ 1028], 4-eckiger Basis in 3 Stücken. Auch auf dem oberen Ablauf Schrift. 
H. 0.22 (oben) + ca $1.05+0.31$ (samt Ablauf), B. 0.66 (Schaft), D. 0.66 (Schaft). Buchstaben 0.045 (Ablauf), 0.035 (Schaft), sehr verwaschen'.

The inscription is illegible.

It dates to the first half of the third century $\mathrm{AD}$, as the base is of the same type and design as YÇ 1027 and 1028 (nos 6 and 7).

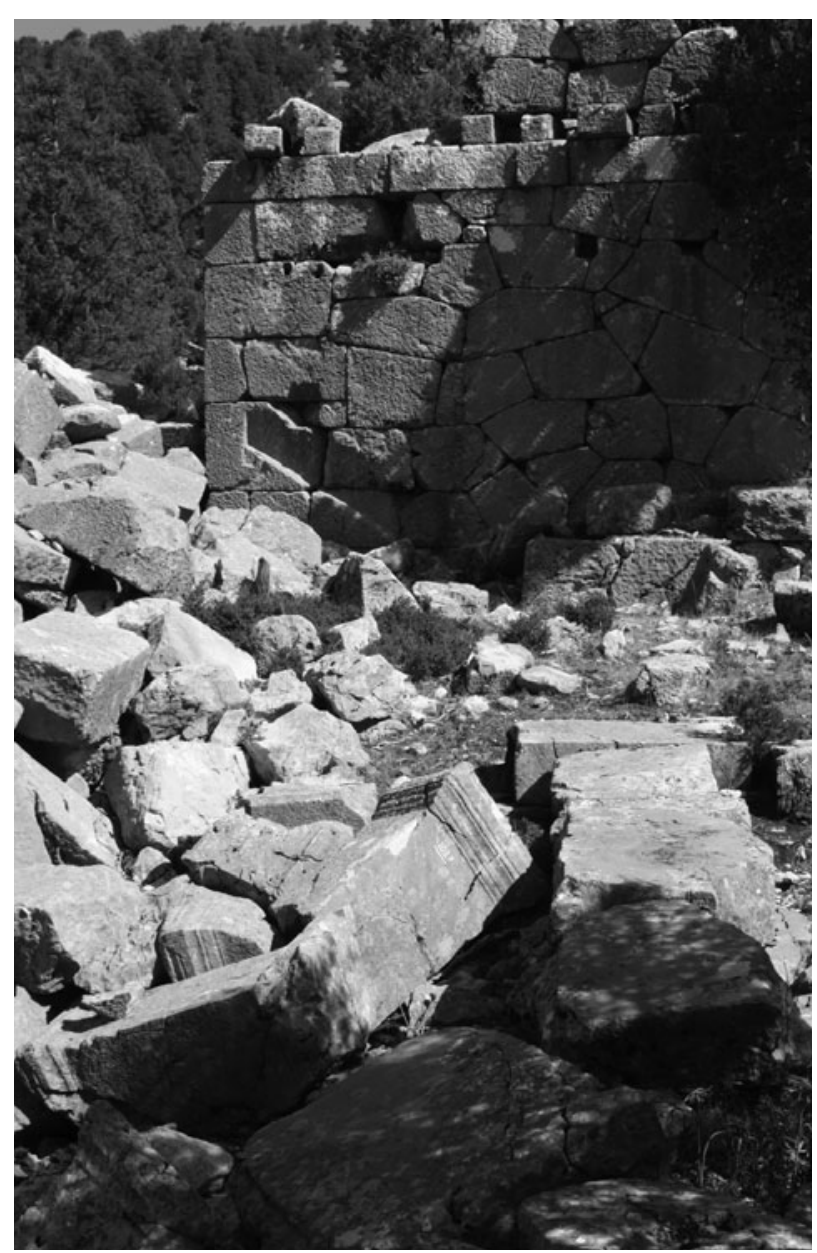

Fig. 20. YÇ 1026 and 1027 context, looking along northwestern stoa towards northern corner of Ml 2.

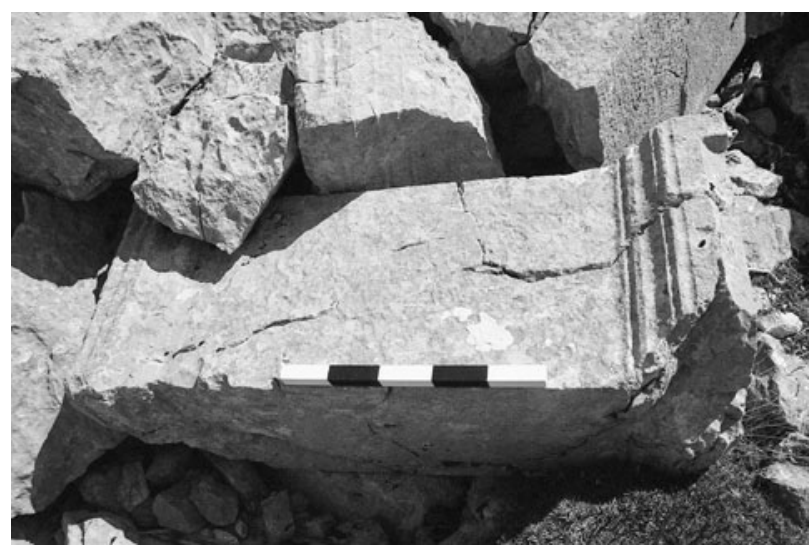

Fig. 21. YÇ 1026, 1027 behind it.
6. Statue base for Aurelius Diogenes, boy boxer (previously published)

YÇ $1027=$ WS $115=$ Hall, Milner 1994: 21 no. $14=S E G$ 44.1178. Peristyle court Ml 2.

A limestone statue base (fig. 25) with the top broken off, lying in heavy rubble $1 \mathrm{~m}$ west of the northern corner of the central court, in the peristyle walk. Height $0.85 \mathrm{~m}$ (shaft), $0.3 \mathrm{~m}$ (foot); width $0.56 \mathrm{~m}$ (shaft); thickness $0.58 \mathrm{~m}$. Letters $2 \mathrm{~cm}$.

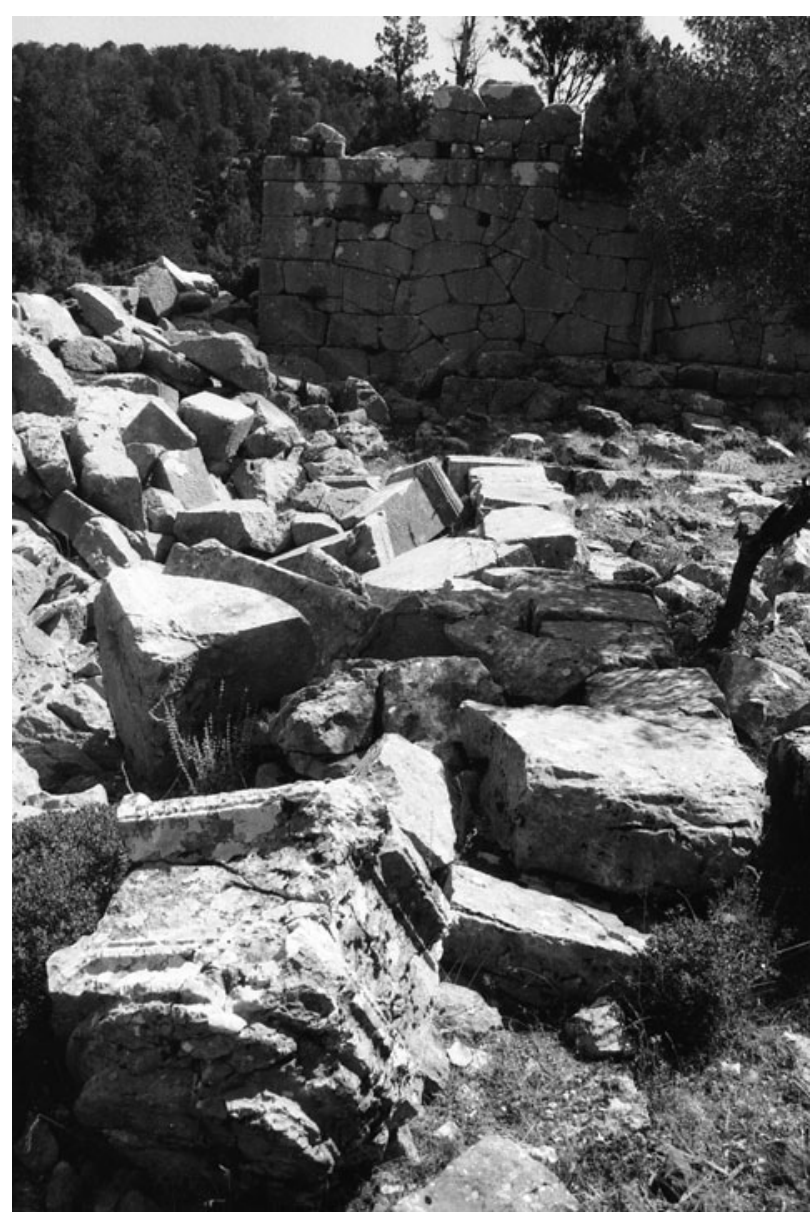

Fig. 22. YÇ 1152 context, northwestern stoa of Ml 2.

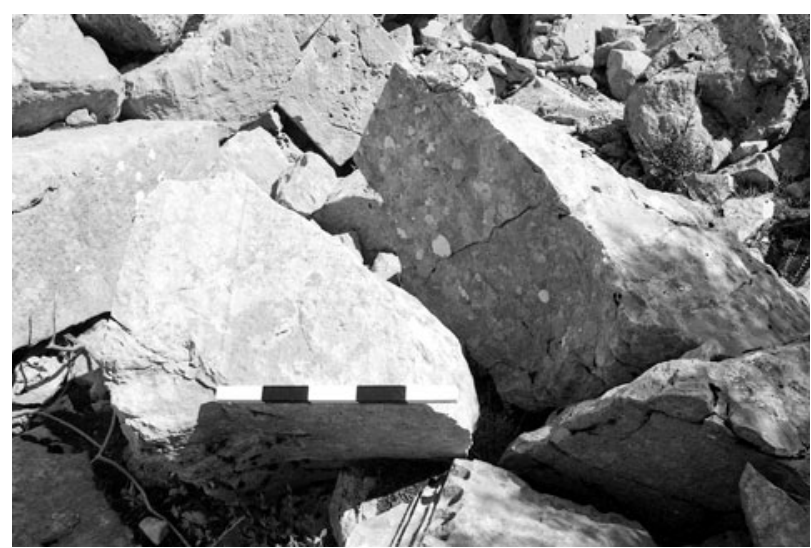

Fig. 23. YÇ 1152 base, broken in three pieces. 


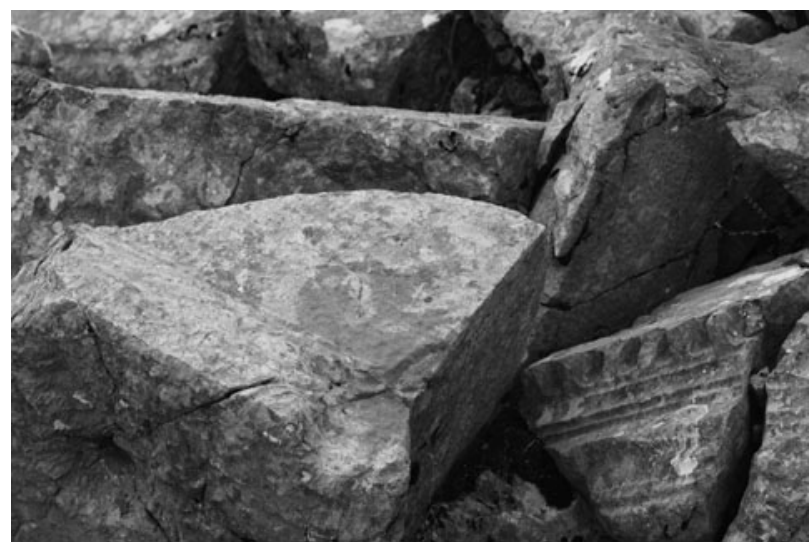

Fig. 24. YÇ 1152 top.

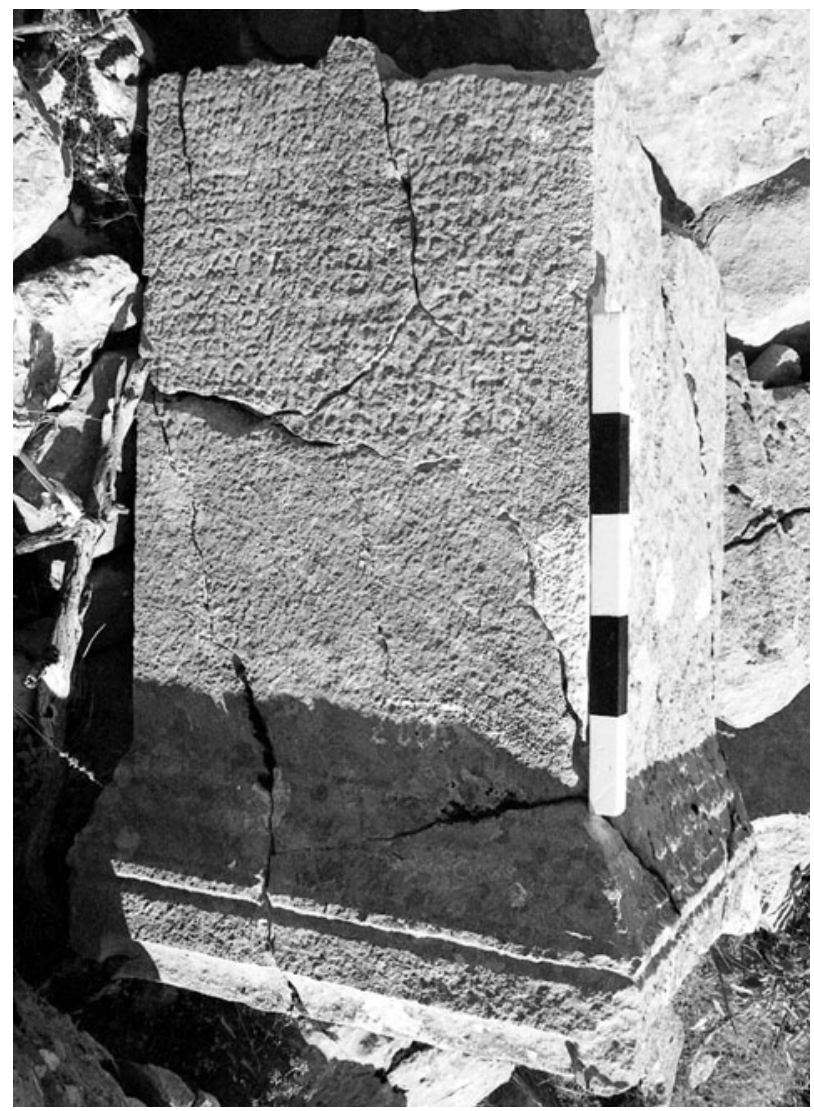

Fig. 25. YÇ 1027.

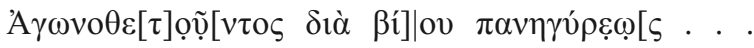

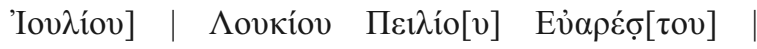

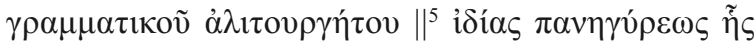

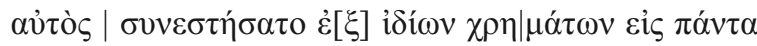

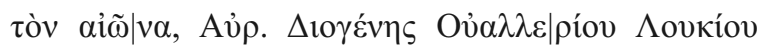

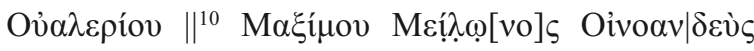

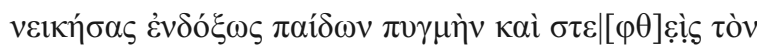

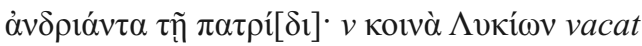

When Iulius Lucius Pilius Euarestos, grammatikos (schoolmaster) with immunity from local liturgies (taxes and services), was agonothetes (festival organiser) for life of the ...nth panegyris (festival), his own panegyris which he founded with his own money for all time, Aur(elius) Diogenes, son of Valerius Lucius (or son of Valerius son of Lucius), son of Valerius Maximus (or son of Valerius son of Maximus), son of Milo, citizen of Oinoanda, having won with distinction in the boys' boxing and having been crowned (set up) the statue for his city. (In the games) open to all Lycians.

Date. First half of the third century AD, after AD 212, perhaps AD 235-238, as the Euaresteia festival concerned does not have an imperial title (Hall, Milner 1994: 29). The name of Aurelius dates the inscription to after the constitutio Antoniniana of AD 212.

7. Statue base for M. Aurelius Ammianos, wrestler (previously published)

YÇ $1028=$ WS $114=$ Hall, Milner 1994: 22 no. $15=$ SEG 44.1179. Peristyle court Ml 2.

A limestone statue base with the top broken off, lying half-toppled from the stylobate on the western side of the court Ml 2, about $3 \mathrm{~m}$ south of the western corner of the central court, and supported by a tree (figs 17,26). Height $1.2 \mathrm{~m}$ (broken above); width $0.9 \mathrm{~m}$ (foot), $0.68 \mathrm{~m}$ (shaft); thickness $0.94 \mathrm{~m}$ (foot), $0.76 \mathrm{~m}$ (shaft). Letters $2.5-3 \mathrm{~cm}$.

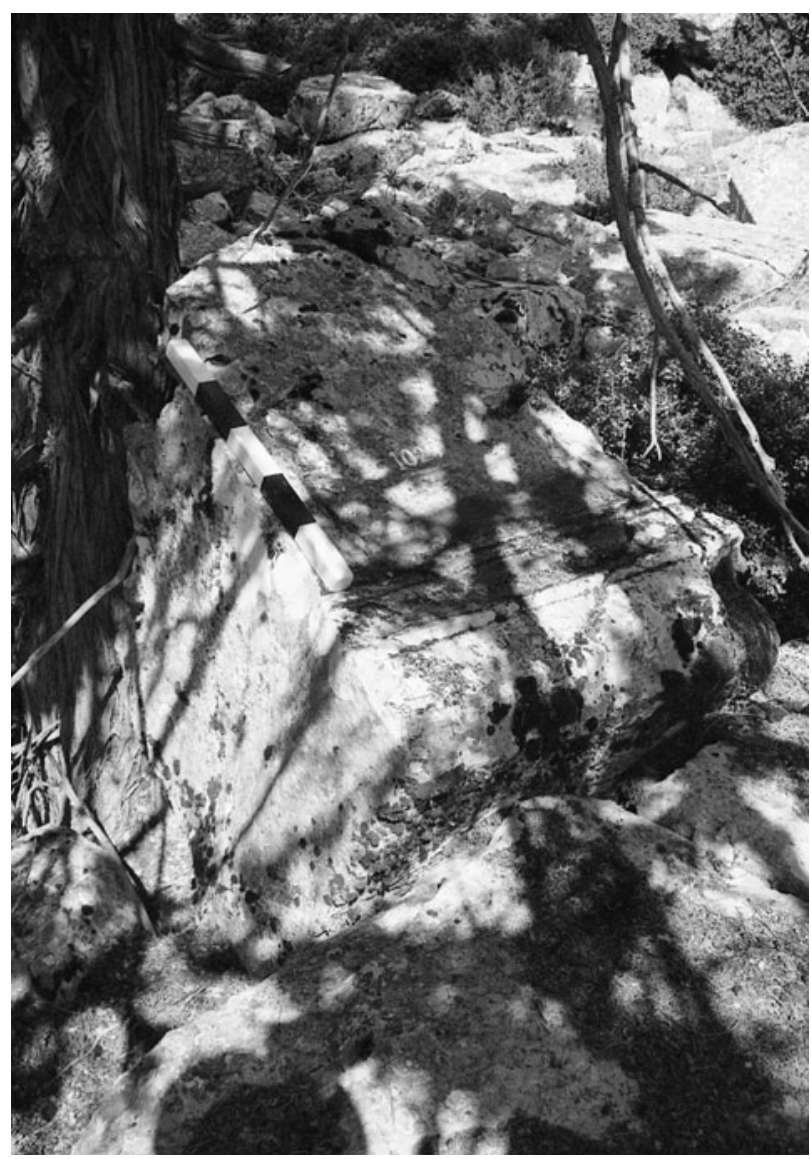

Fig. 26. YÇ 1028. 


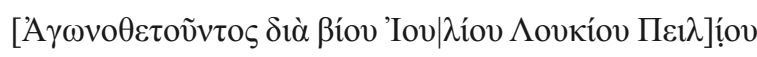

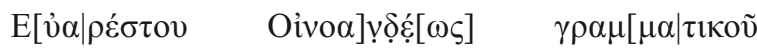

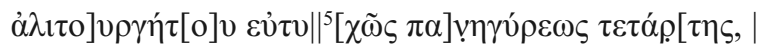

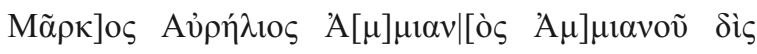

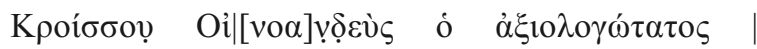

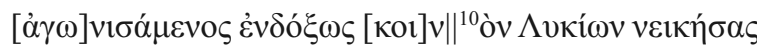

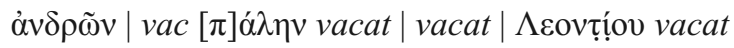

When Iulius Lucius Pilius Euarestos, citizen of Oinoanda, grammaticus with immunity from local liturgies, was agonothetes for life propitiously of the fourth panegyris, Marcus Aurelius Ammianos, son of Ammianos, son of Ammianos, son of Kroisos, citizen of Oinoanda, the Most Honourable, having taken part with distinction in the games open to all Lycians, and having won the men's wrestling. (Statue of/long life to?) Leontios.

Date. Post AD 212, probably AD 235-238, to which the fourth celebration of the Euaresteia festival has been dated (Hall, Milner 1994: 29). The names Marcus Aurelius date the inscription to after the constitutio Antoniniana of AD 212. The name 'Leontios' at the end may be a signum, an informal or nickname, perhaps meaning 'lion-like', that was used, for example, in acclamations of the victor. It is unclear why it is in the genitive case. Alternatively, it may be a later inscription reflecting reuse of the base; if so, however, the reason for the honouring of 'Leontios' is not given.

\section{Conclusions about the building complex MI 1-MI 3}

The bathhouse building Ml 1 has already been dated on architectural grounds, including the associated aqueduct to the south of the city, to the reign of Vespasian (Coulton 1983: 8-9). The new inscription YÇ 1261 dedicating the building to Vespasian, Titus and Domitian is, because of its findspot, almost certainly part of the baths and confirms the date of completion as AD 73. As was stated earlier, the inscription suggests that it was associated with peristyles.

The baths building Ml 1 itself, so far as the unexcavated ruins allow us to see, does not have any visible exterior stoas, except an adjoining peristyle court (building Ml 2), which in its present state is a later structure, of the second or third century AD, and built on a more southerly alignment than the bathhouse. Andrew Farrington observes, however, that the outer side of the western wall of room 2 of Ml 1 has 20 beam-holes for the roof of a possible portico on what would have been the eastern side of an adjoining structure belonging to an earlier phase on the site of Ml 2 before it was redeveloped, realigned, with lower stoas (fig. 27). Secondly, he notes that the podium for the palaistra in front of the later baths building Mk 1 was originally constructed on an alignment corresponding to building Ml 1 on the other side of the street. He suggests that both were sites of potential palaistras associated with Ml 1, and while that across the street was later reoriented and remodelled with a Severan portico and attached to building Mk 1 after that bathhouse (which is usually iden-

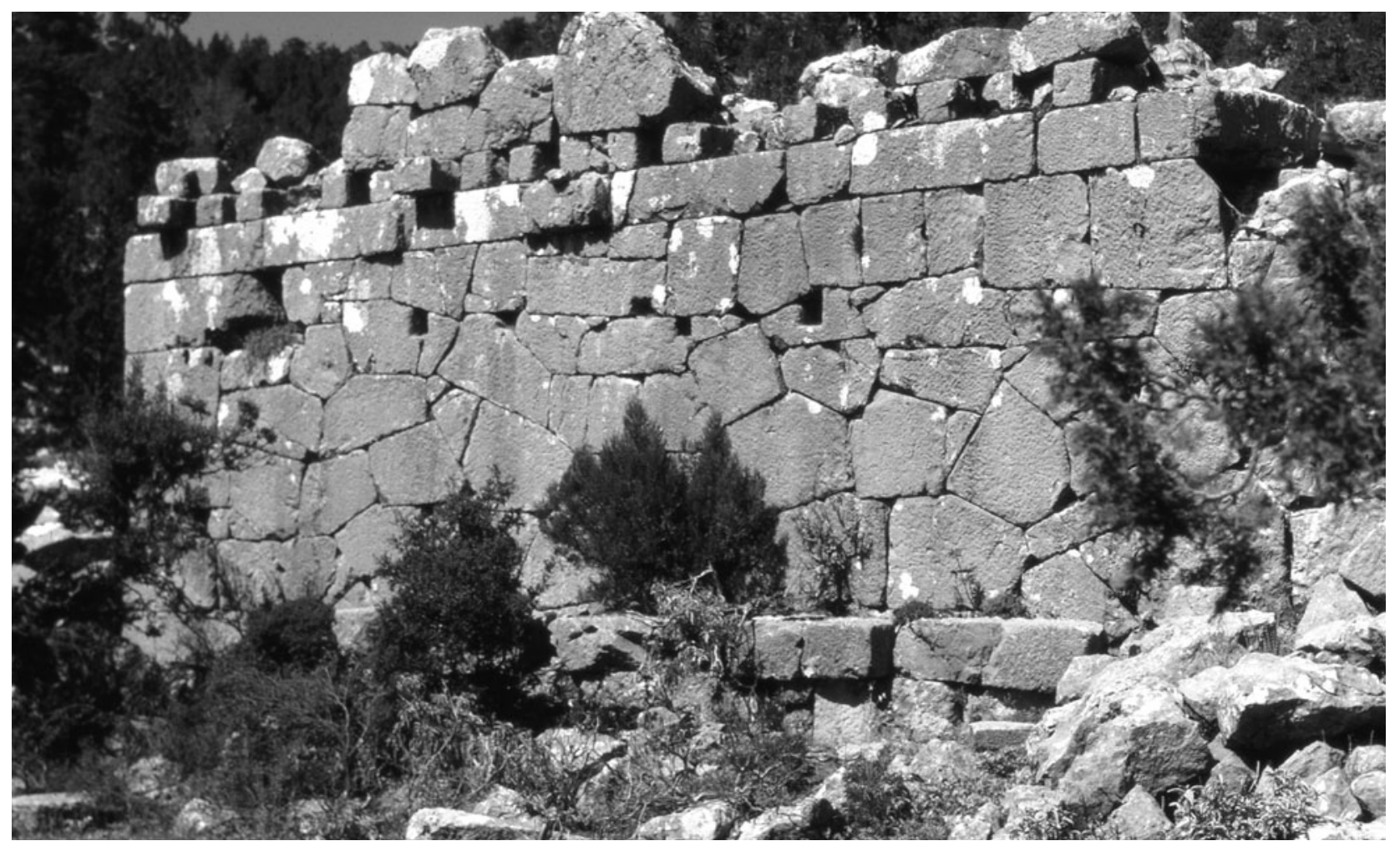

Fig. 27. Ml 2 eastern wall, Ml 1 western wall, in 1981 (by A.S. Hall). 


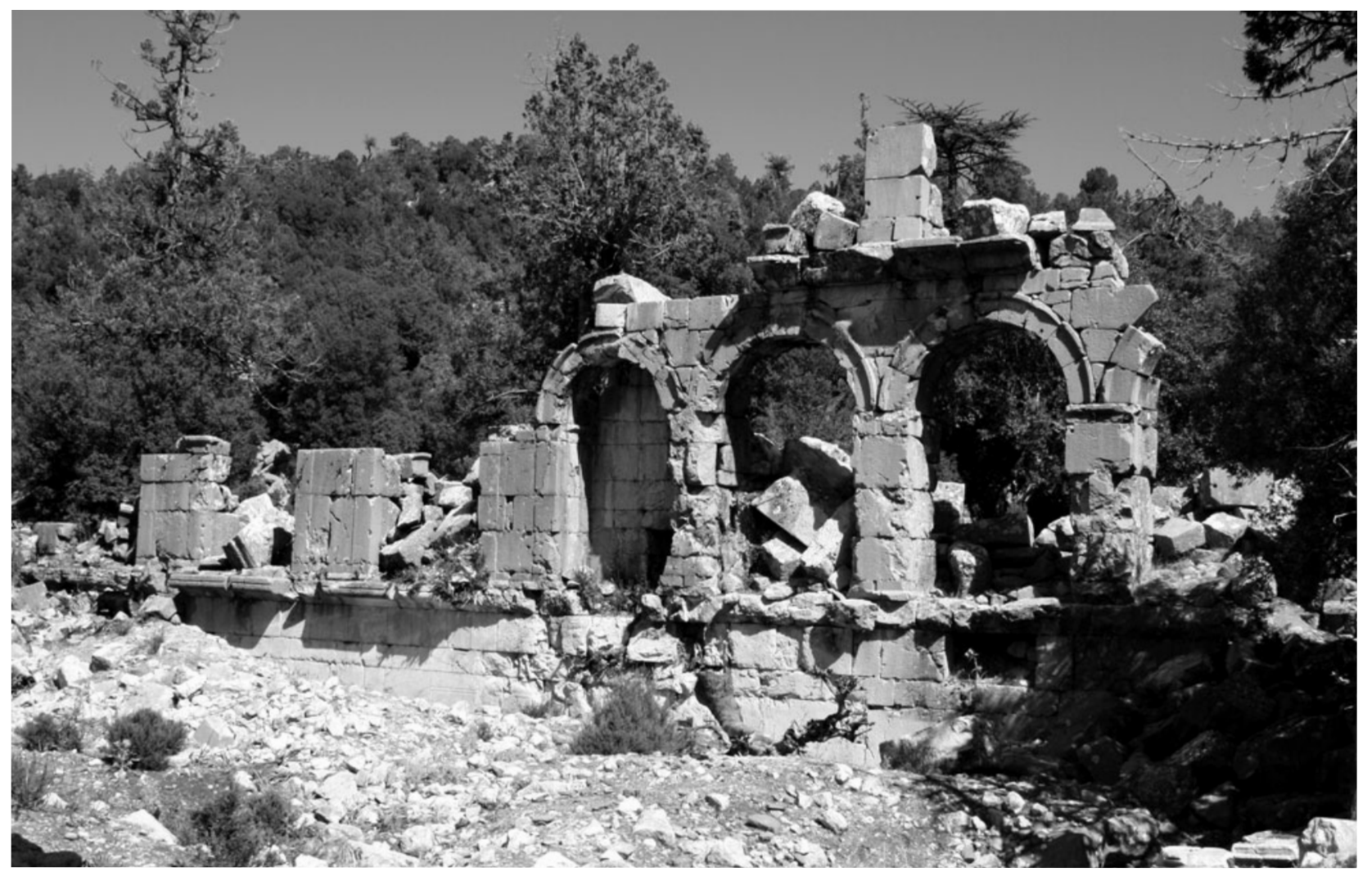

Fig. 28. Baths building Mk 1.

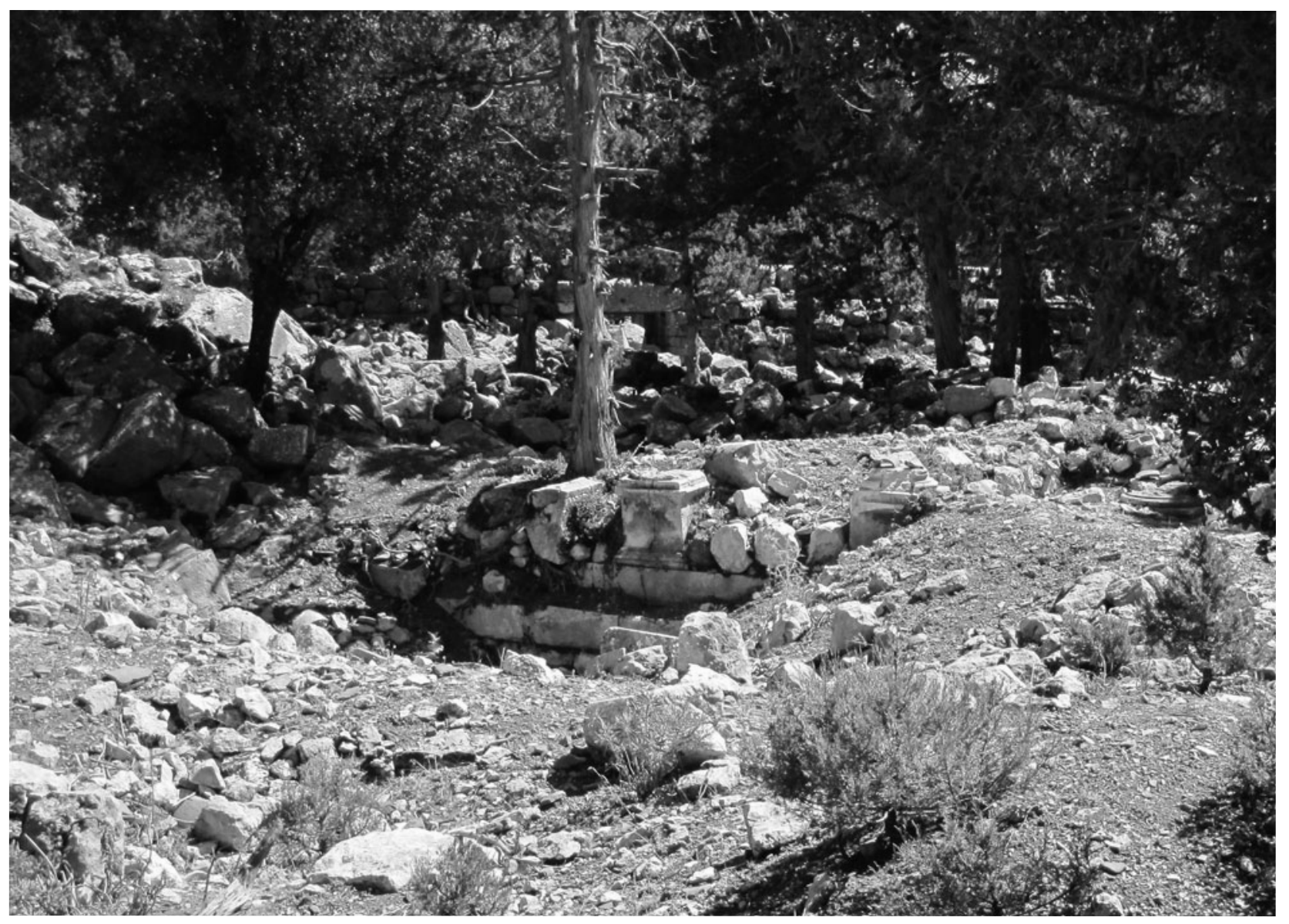

Fig. 29. Eastern side of Mk 1 colonnade, three column bases. 
tified with an epigraphically attested donation by Opramoas of Rhodiapolis) was constructed in the mid second century (figs 28, 29), Ml 2 was rebuilt with the presently visible remains of a peristyle court also in the Severan period (fig. 2; Farrington 1995: 61-62, 67-68, 155-56).

The newly found inscribed block for building Ml 1 itself is perhaps evidence of a Flavian peristyle, for it was designed to be visible and accessible from below, having an Ionic-decorated soffit one could perhaps walk under. It might have belonged to an entrance, for example, to an earlier structure on the site of building Ml 2, and either survived any reconstruction works or else was repositioned there in a later structure from which it has fallen with the surrounding heavy debris. It follows, then, that if there were Flavian peristyles near to or connected with the baths building Ml 1, they have now to be inferred rather than seen. The surrounding areas were undoubtedly remodelled after the Flavian period, and the northeastern street itself was furnished with a colonnade of Ionic columns on pedestals on its northern side, opposite building Ml 1, at some time in the Antonine to Severan period, together with a monumental arch, Ml 6, that was erected across the street outside building Ml 2 perhaps in the Severan period (in fig. 2, 'Ml 6' shows the approximate position; see Coulton 1986: 76, 89).

All the inscribed monuments in building Ml 2 except the illegible tabula ansata inscription YÇ 1287 can be assigned to the first half of the third century AD. YÇ 1287 which is built into a wall that seems contemporary with the second phase of building M12, when the peristyle court that is presently visible was laid out on a more southerly alignment than the western wall of room 2 of the bathhouse building Ml 1, will very probably date to the construction of the second phase, and this will most likely pre-date the other inscribed monuments in the court. The architectural remains of pedestal column bases that are scattered about the court have been dated, like others at Oinoanda, on stylistic grounds to the late second/early third century, particularly the reign of Septimius Severus (Susan Walker quoted by Ling 1981: 42 n.16, 34-35 n.4; compare Coulton 1983: 10). All three legible inscriptions in building Ml 2 are for athletes, probably from the third and fourth decades of the third century. There were certainly at least two other statues on inscribed bases, and probably others, erected around the perimeter of the court. Farrington counted six inscribed bases (1995: 156), presumably including in this total other bases to be seen lying or buried in heavy rubble in the northwestern stoa.

If building Ml 2 is a palaistra or 'wrestling-school' as suggested by Jim Coulton (1983: 9), and his argument is right about the identification with a wrestling-school of the boukonisterion dedicated to Septimius Severus in an agora building inscription on an imperial statue-monument

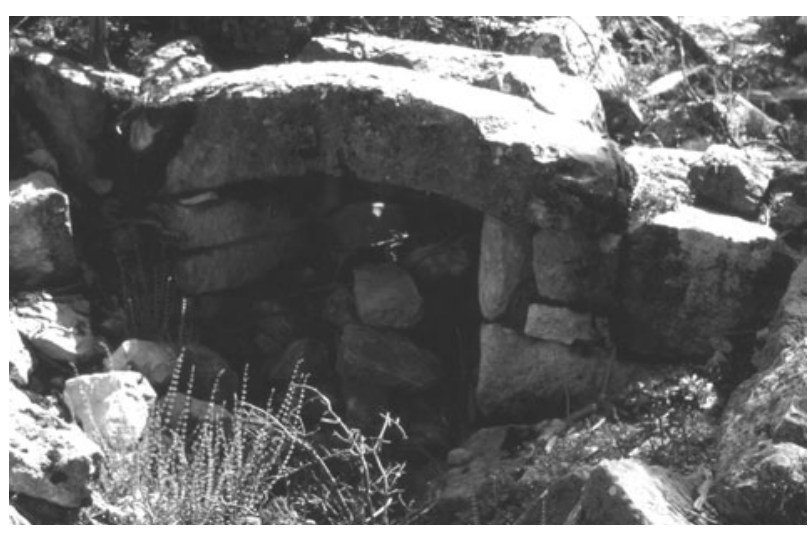

Fig. 30. Covered drain south of Ml 3 looking west, in 1981 (by A.S. Hall).

(building Ml 4), then the boukonisterion may be identical with the palaistra, and the date of the boukonisterion inscription - assigned to AD 193-197/198 (Milner 2015: 184) - may also be the date of the second phase of building Ml2. Another of the attractions of the boukonisterion identification is proximity, in that it appears that it may have been possible to gain entrance to building Ml 2 by way of a corridor or alleyway accessed by passing behind building Ml 4 and along the line of a large, formerly covered, drain (figs 30, 31); the alley appears to align with the southern passage beside the statue monument.

Proximity and access are also relevant to the question whether the small, possibly courtyarded building Ml 3, which is more immediately behind the statue-monument $\mathrm{Ml}$ 4 and occupies the space between Ml 2 and the agora's northeastern stoa $\mathrm{Ml} 5$, belongs to the same complex (fig. 31 ). It was built, at any rate, after $\mathrm{Ml} \mathrm{2,} \mathrm{but} \mathrm{before} \mathrm{Ml} 5$, and could well be contemporary with either (see Coulton 1986: 81, 65). This seems a suitable place to record that YÇ 1211, an unpublished building inscription for an agoranomion or market office, which is dated as early as the reign of Augustus, and which was found in rubble fallen from the northwestern wall of building Ml 3 on the street side in 2008, will therefore have been a block reused in that location, its inscription no longer relevant to the time of construction of $\mathrm{Ml} 3$ except as a remote terminus post quem.

\section{Provincial governors of Lycia and Lycia-Pamphylia in the reign of Vespasian, AD 69-79}

The names of $\Phi$ íp $\mu$ ov, the praetorian governor of LyciaPamphylia who dedicated the building in our inscription no. 1 (YÇ 1261; figs 10, 32), have recently been confirmed in full by a Latin and Greek bilingual roadbuilding inscription from Döşeme Boğazı, a pass on the via Sebaste between Pamphylia and Pisidia, which is dated by Vespasian's fourth consulship to AD 72 (Adak, Wilson 2012: 6-11 = AE 2012: 1703): Gnaeus Avidius Celer Rutilius Lupus Fiscilius Firmus. All other inscribed 


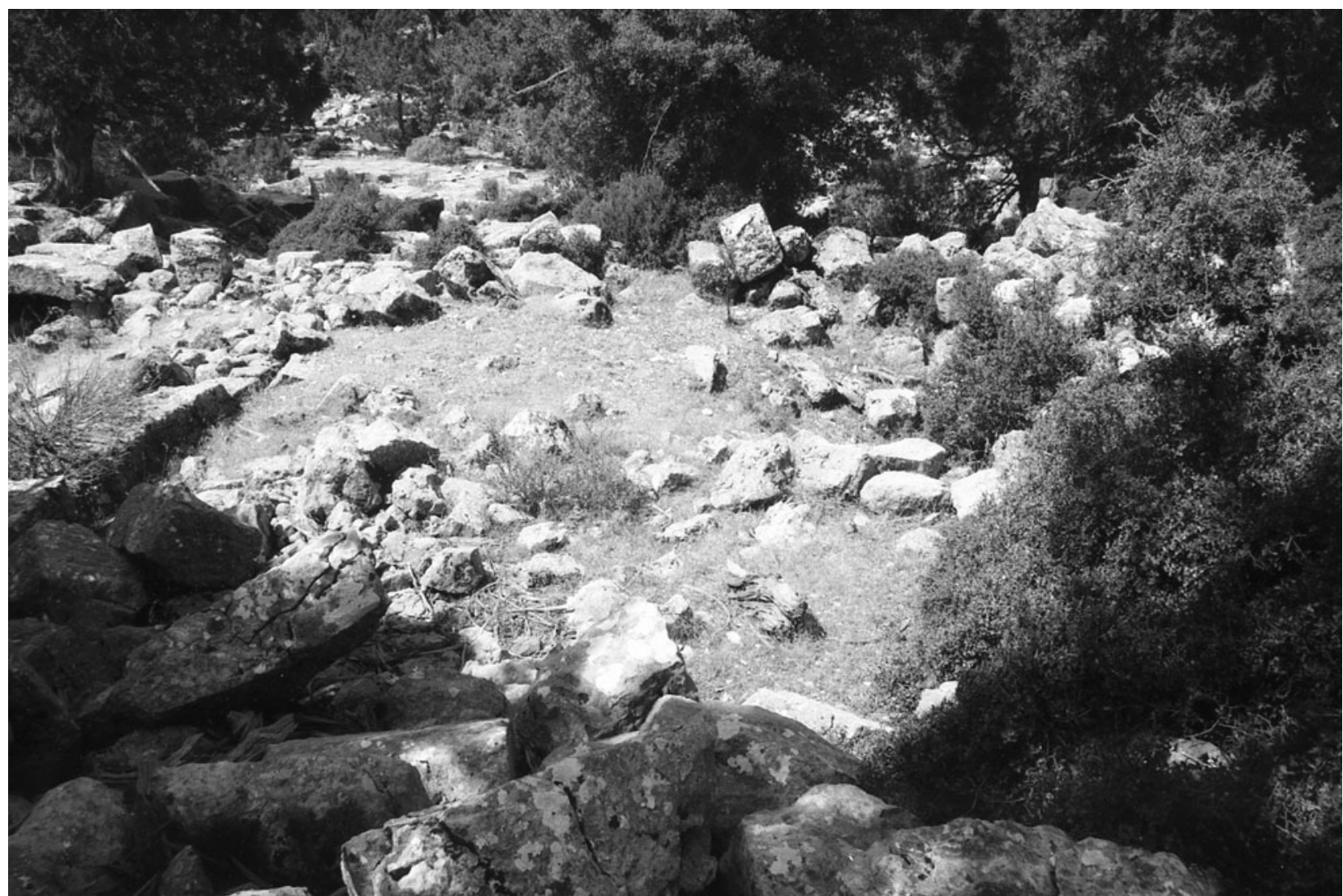

Fig. 31. Ml 3, interior, looking south towards the agora, covered drain on left.

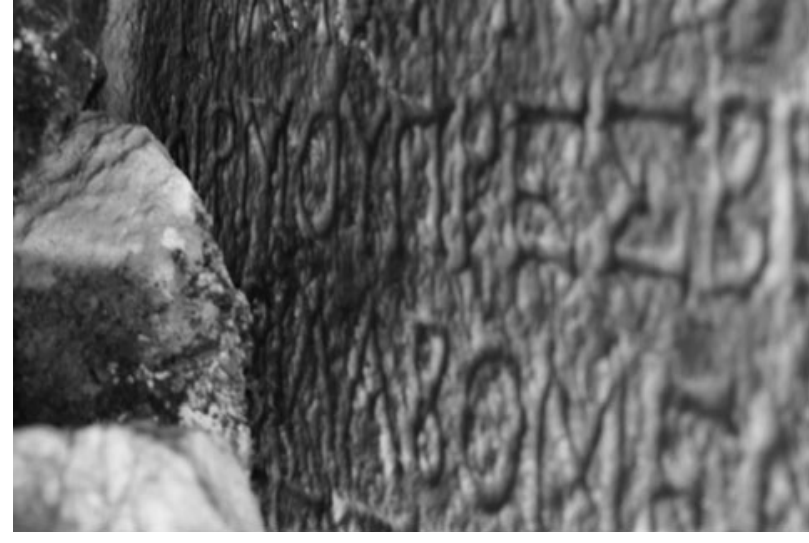

Fig. 32. YÇ 1261, name of Firmus.

occurrences of his names but one (I.Kaunos 123) omit Rutilius Lupus. Fiscil(l)ius where it was partly preserved had previously been misread as Fiscillinus (compare TAM 2.701 from Araxa). Although our inscription preserves only the final name, there is no doubt about the identity of the governor. The date of his governorship of LyciaPamphylia is now securely attested by our inscription for the year AD 73 and by that at Döşeme Boğazı for AD 72 . It had already been dated by W. Eck to ca. AD 72-74 by a process of elimination which is vindicated by recent finds (Eck 1970: 74).
M. Adak and M. Wilson also recently dated two other epigraphic attestations of Firmus from Myra and Kaunos to late AD 70 (Adak, Wilson 2012: 12-13, nos 5-6), leading to a proposed date for Firmus' governorship of ca 70-72. This involved shifting the governorship of Marcus Hirrius Fronto Neratius Pansa down to AD 72-74, which Eck (after Torelli 1968: 174) had dated to ca AD 70-72. The new evidence from Oinoanda precludes the switching of Pansa's and Firmus' Lycian administrations. In view of the new inscription and the aqueduct inscriptions at Balboura dated AD 74-76 (SEG 28.1218 = AE 1978: 804; Milner 2012: 83 no. 1), these imperial dedications from Myra and Kaunos under the governorship of Firmus can with greater probability be supplemented with the titulatures of Vespasian and both his sons, and redated to AD 73.

Thus the acephalous inscription Adak, Wilson 2012: 12 no. $5+I G R 3.725=A E$ 2012: 1638 (Myra), which seems to have been inscribed on a wall or monument of which just two dismembered inscribed blocks have thus far been found, should perhaps be restored in lines 0-1 somewhat as follows, with lines $2-4$ restored after Jones 2014: 28: 
0 [-------some lines of titulature for Vespasianus Augustus and Titus Caesar missing-------]

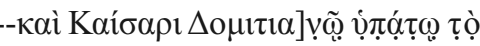

$\beta^{\prime}, \operatorname{Mv\rho \varepsilon ́}[\omega v] \dot{o ̣}[\delta \tilde{\eta} \mu о \varsigma]$

2

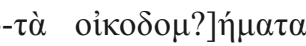
$\pi \varepsilon \sigma o ́[v] \tau \alpha \dot{\varepsilon} v \tau \tilde{\omega} \gamma \varepsilon[v o \mu \varepsilon ́ v \omega]$

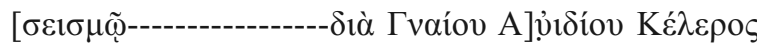

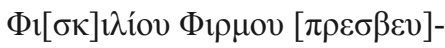

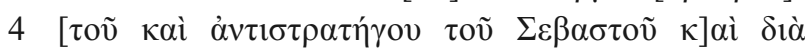

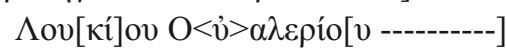

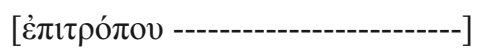

[To the emperor Vespasianus Augustus ... and to Titus Caesar ... and to Caesar Domitia]nus, consul for the second time, the [People] of the Myrans .... [restored ... the public build]ings fallen in the for[mer earthquake ... through the agency of Gnaeus] Avidius Celer Fiscilius Firmus, [legatus Augusti pro praetore], and Lucius Valerius ... procurator ...

Line 1. Domitian's second consulship is dated AD 73 (Kienast 1996: 116).

Line 2. Compare SEG 57.1673; AE 2007: 1519 a-b (Delik-

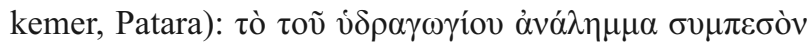
$\sigma \varepsilon 1 \sigma \mu$ oi $\varsigma$, 'the substructure of the aqueduct fallen in earthquakes'; TAM 2. 905 XVII B 11 (Rhodiapolis): $\dot{\varepsilon} v \delta \varepsilon \dot{~} \tau \tilde{\varphi}$ $\gamma \varepsilon v o \mu \varepsilon \dot{\varepsilon} \omega \sigma \varepsilon 1 \sigma \mu[\tilde{\omega}]$, 'in the former earthquake'. See the same inscription at XIX A 9 for another earthquake at Myra.

Likewise, the acephalous I.Kaunos 123, which was evidently inscribed in three lines on an architrave, should perhaps be restored somewhat as follows:

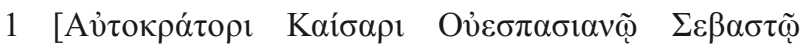

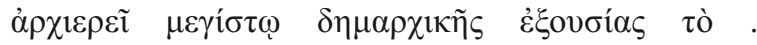

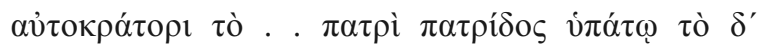

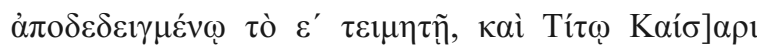

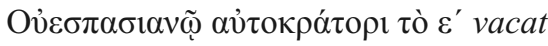

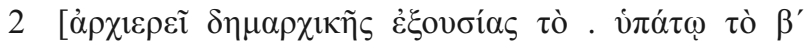

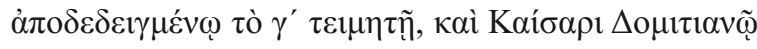

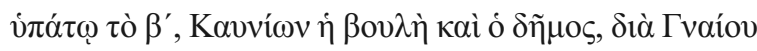

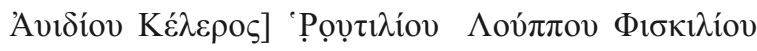
vacat

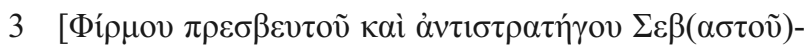
-] vacat

[To the emperor Caesar Vespasianus Augustus, chief pontiff, with tribunician power for the ...nth time, imperator for the ...nth time, father of the fatherland, consul for the fourth time, consul designate for the fifth time, censor, and to Titus Caes]ar Vespasianus, imperator for the fifth time, [pontiff, with tribunician power for the ...nth time, consul for the second time, consul-designate for the third time, censor, and to Caesar Domitianus, consul for the second time, the Council and People of the Kaunians (dedicated it), through the agency of Gnaeus Avidius Celer] Rutilius Lupus Fiscilius [Firmus, legatus Aug(usti) pro praetore...].

Line 1. Titus' fifth imperatorial acclamation is dated to AD 73 (Kienast 1996: 112). This detail shows that the imperial titulature of Vespasian, Titus and Domitian was written out in full, making a lengthy inscription of it along the architrave, such as for a stoa.

The result of such revision is to bring both building inscriptions into the same time frame as already indicated by the evidence from Döşeme and Oinoanda, and to support Firmus' period of office in at least AD 72-73. It follows that L. Valerius... (no cognomen preserved), attested potentially as procurator in the Myra inscription, was a successor to P. Anicius Maximus attested at Döşeme, not a predecessor. It emerges too that the Roman authorities were extremely busy at this period overseeing the construction of and opening complex new public buildings in various far-flung cities and attending to road building in remote corners of the newly combined province of Lycia et Pamphylia. This gives us a synchronic view of a Roman provincial administration that was managing an unexpectedly large workload of this type, with a very small number of staff. They were reacting to construction works happening simultaneously all over the province through the local leadership of the pro-Roman civic elites employing all the local resources they could command, and yet the small size of the governor's cohors, which was staffed by his relatives, friends, freedmen and slaves, will have made it quite impossible for them to be directing all these grands projets in many cities at once. The genius of the Roman system was its ability to stimulate the provincials to develop themselves, within an effective political, legal and financial framework overseen by Rome.

The dating of all the above-mentioned inscriptions for Firmus to AD 72-73 thus leaves room for Pansa to be governor right after Sextus Marcius Priscus, whose dates are AD 63/64-70/71. Pansa, who is attested as praetorian governor of Lycia in inscriptions at Xanthos, Letoon and Tlos, needs to have held the consulship shortly thereafter (Eck 1970: 69). M. Torelli (1968: 174) suggests AD 73 or 76, W. Eck (1974: 283-85) proposes AD 74 and R. Syme (1983: 143 n.142) offers 'suff. ca AD 75'. The consulship preceded his appointment to other probably consular positions culminating in the consular governorship of 
Cappadocia-Galatia, ca AD 77/78-79/80 (Torelli 1968: 173-74). A praetorian legateship in Lycia becomes progressively less likely after AD 72, and the only obvious gap in the provincial fasti after AD 70/71-72 where it could be inserted, AD 76-78, is surely too late. A statue base from Oinoanda, which had been attributed to Pansa and published by Hall (1984: 27-35), can now be securely attributed to another governor (compare Adak, Wilson 2012: 28 n.130; this will be treated in a future article).

Firmus' successor is likely to be L. Luscius Ocrea, in post ca AD 74-76, who used to be seen as the first indubitable governor of the joint province of Lycia-Pamphylia (Brandt 1992: 98). Following the discovery of the Döşeme inscription, however, that honour now belongs to Firmus. It is worth repeating that there is no reliable evidence of an era dating from the foundation of the joint province (compare Eck 1970: 72; Leschhorn 1993: 414-15; Horsley 2007: 75 no. 108 Akören). There is good reason to identify as Ocrea the governor of Lycia-Pamphylia who received a physical honour, perhaps a statue, at Rhodiapolis (SEG 58.1637; $A E$ 2008: 1437; İplikçioğlu 2008: 15). Half of the Greek form of what could be his cognomen, ['Ок] $\alpha$, may be read in line 1 of the preserved part of the inscription before $\pi \rho \varepsilon\{\rho \varepsilon\} \sigma[\beta] \varepsilon v \tau \eta \tilde{~(s o, ~ O . ~ S a l o m i e s, ~} A E$ 2008: 1437; Adak, Wilson 2012: 17 n.58). Like Pansa, Ocrea was adlectus inter patricios, 'elected to the patricians', by Vespasian and Titus in the exercise of their censorial function in AD 73-74 (Newton 1902: 29-31; Torelli 1968: 174). The patricii appear to have been a group of specially favoured men, who included Cn. Iulius Agricola and Annius Verus, the grandfather of the emperor Marcus Aurelius (Tacitus Agricola 9; Scriptores Historiae Augustae vita Marci 1). These were accounted worthy to lead a new senatorial aristocracy, purged of loyalty to the Julio-Claudians (Suetonius Vespasianus 9). The fact that the Rhodiapolitan base records a legionary legateship of legio III Gallica held 'in Syria', a legion which was normally stationed there before it was transferred to Moesia by Nero ca AD 67 and which returned there not long after the Battle of Cremona in AD 69 (İplikçioğlu 2008: 16 n.65; Adak, Wilson 2012: 16), allows the legionary command in Syria to follow the civil war. Nothing is known about Ocrea's military career to contradict this. There is no need to postulate, with B. İplikçioğlu, an otherwise unknown Lycian governorship of C. Dillius Aponianus just because he commanded legio III Gallica at Cremona (Tacitus Histories 3.10.1).

Adak and Wilson's preferred identification of the Rhodiapolitans' honorand, however, is not with Ocrea but Firmus. This is possible, since nothing is known of his military career either, but it is most unattractive to leave unresolved the letter traces at the beginning of line 1 of the preserved inscription. It is only an hypothesis that the inscription's 'early' order of names in the titulature for
Vespasian, being the Greek equivalents of Imperator Vespasianus Caesar, instead of the standardised Imperator Caesar Vespasianus Augustus (see Adak, Wilson 2012: 17) which is the order found in inscriptions attesting Firmus (TAM 2.1188, Phaselis; TAM 2.132; IGR 3.521 + 1509, Lyde) and Ocrea (SEG 28.1218; AE 1978: 804, Balboura), would support Firmus rather than the latter. A fortiori, it would still more favour Pansa's being the honorand, although there seems hardly enough time for Pansa to be legate of legio III Gallica in Syria after its return from Italy, perhaps as early as AD 70, and governor of Lycia in succession to Priscus, who probably left office in AD 70 after an extraordinary span of eight years in the post (SEG 57.1672B; $A E$ 2008: 1447, Patara). If it is for Firmus, the Döşeme inscription from AD 72 exhibits another non-standardised titulature, the Greek equivalents of Imperator Caesar Augustus Vespasianus, where the bilingual Latin text is mostly missing. However that may be, dating based on such an artificial criterion must be very doubtful.

Ocrea will have been succeeded by an ignotus, between ca $\mathrm{AD} 76$ and 78. For the exclusion of M. Petronius Umbrinus, who was formerly attributed to LyciaPamphylia at this time, but is now assigned to Cilicia in AD 78-80, see Sayar 1992: 57-58; Birley, Eck 1993: 4554. Ignotus was followed by T. Aurelius Quietus, who was in office before and after the death of Vespasian on 23rd June 79, thus ca AD 78/79-80/81 (Adak, Wilson 2012: 27 28; AE 2006: 1511-12, Olympos, with commentary by M. Sève amending IGR 3.724, Myra; $A E$ 2010: 1634, Perge).

\section{The arrival and adaptation of Italian-style bathing in southern Asia Minor and Lycia}

The bathing part of the bath-gymnasium complex as developed in Asia Minor in the imperial period followed Italian models introduced by the Romans, in which vaulted rooms were heated to different temperatures and bathing in communal plunge-pools was provided for. In Asia Minor, this Italian implant was simply grafted onto the pre-existing Hellenistic gymnasium or palaistra, a flat open space surrounded by stoas; one of the earliest examples is the Baths of Vergilius Capito at Miletos, which are dated to AD 43 (Yegül 1992: 250-56). There were earlier $\beta \alpha \lambda \alpha v \varepsilon i \alpha$, 'baths', such as at Assos (IGR 4.257, reign of Tiberius) and Kyme (IGR 4.1302, reign of Augustus), but if these did not follow the Italian design, they may have provided merely cold-water washrooms equipped with rows of hand-basins and hip-baths, as in other parts of the earlier Greek world. One earlier baths complex of Italian type has recently been discovered under the second-century imperial baths at Sagalassos; dated AD 10-30, it was equipped with apsidal warm, tepid and cold-water rooms, presumably to meet the sophisticated demands of Italian veterans settled in the vicinity by Augustus (Waelkens 2014: 19). 
The physical, functional and cultural association of baths with gymnasia led to the interchangeability of terminology, so that in southwestern Asia Minor, at least, $\gamma v \mu v \alpha ́ \sigma ı v$, originally merely 'exercise-place', could mean $\beta \alpha \lambda \alpha v \varepsilon i o v$, 'bath', and vice versa. Lycian baths were probably often labelled $\gamma v \mu v \alpha ́ \sigma ı \alpha$ and the monumental Roman architectural forms of the bathhouses reproduced by Lycian builders, many of which are still standing, will in many cases have had adjoining palaistras which are no longer visible, an open space and a peristyle being easily obliterated by the passage of time (Delorme 1960: 24350; Mitchell 1993: 1.216; Farrington 1995: 135-37). All southern Anatolian bathhouses that have been studied were of the Italian 'thermae type', with a palaistra where they have been sufficiently studied for it to be identified (Ling 1981: 40; Nielsen 1990: 110-11).

The new bathhouse inscription from Oinoanda also points us to a fact that is attested in several of the relevant Flavian bathhouse and aqueduct inscriptions from elsewhere in Lycia: the new buildings being memorialised were restorations or renewals or extensions of older structures. Since, with the exception of the Augustan colonies in Pisidia, the Roman bathing habit really took off in southern Asia Minor about the same date as the annexation of Lycia in AD 43, probably all of the earlier Lycian bathhouses of this type will have been of Claudian or Neronian date. Subject, of course, to future archaeological discoveries to the contrary, it would seem attractive to date the first Roman-style public bathhouse in Lycia to the completion of the first Delikkemer aqueduct for the provincial capital, Patara, under Eprius Marcellus (ca AD 50-54). Its rebuilding, completed at the start of Vespasian's reign, would have allowed the transfer of skilled personnel to build Oinoanda's aqueduct in AD 7173, which bears a resemblance to Delikkemer (figs 33, 34; Coulton 1983: 9; 1986: 56-58). Presumably Oinoanda's earlier baths were also supplied by an aqueduct, of which no trace has been found, unless the existing Flavian aqueduct is based on an earlier structure that was restored. In any event, however, we may probably infer that the earlier structures were built as recently as the AD 50s or 60s. Some implications of this for our understanding of the development of the Roman province of Lycia are discussed further below.

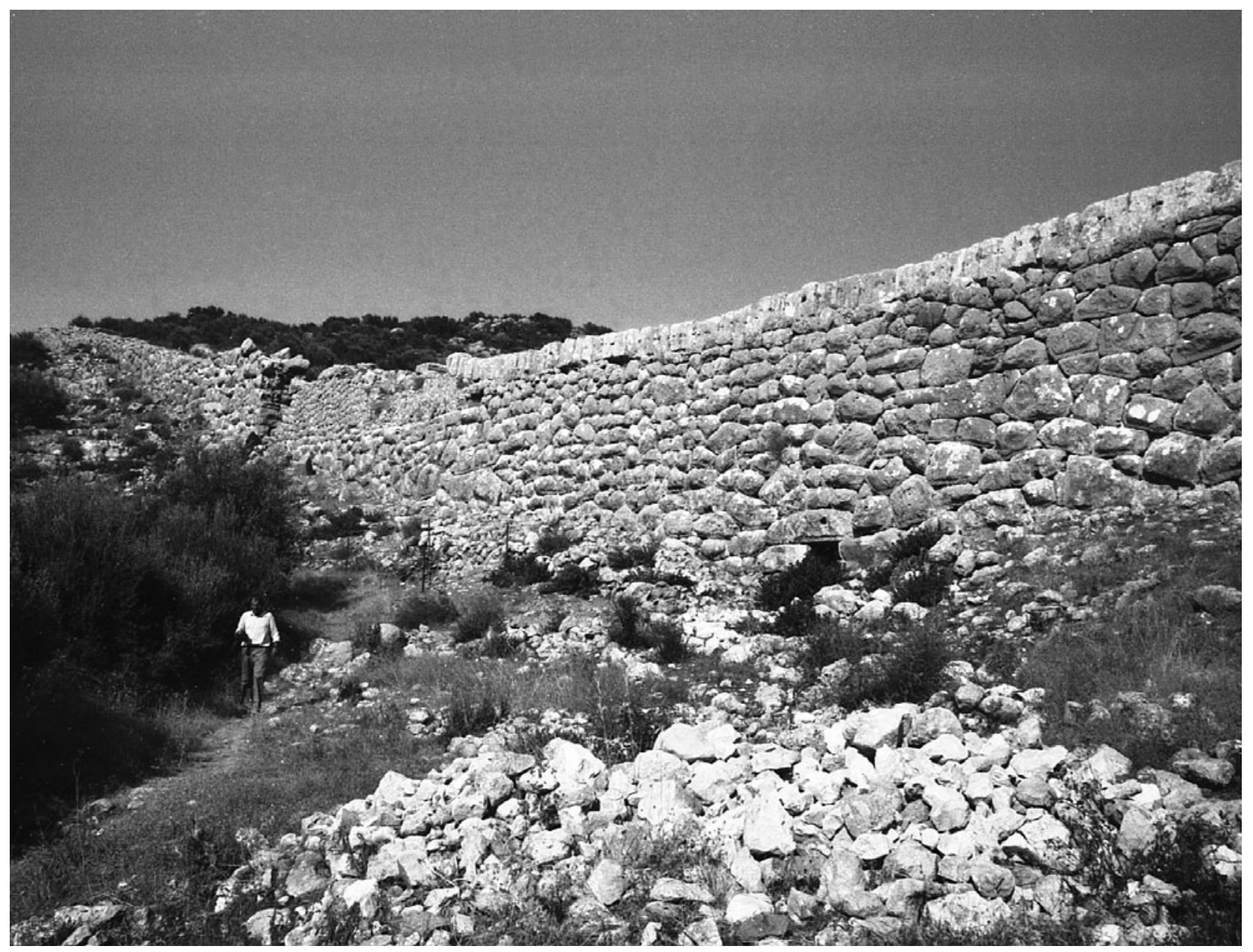

Fig. 33. Delikkemer, Patara, aqueduct above city. 


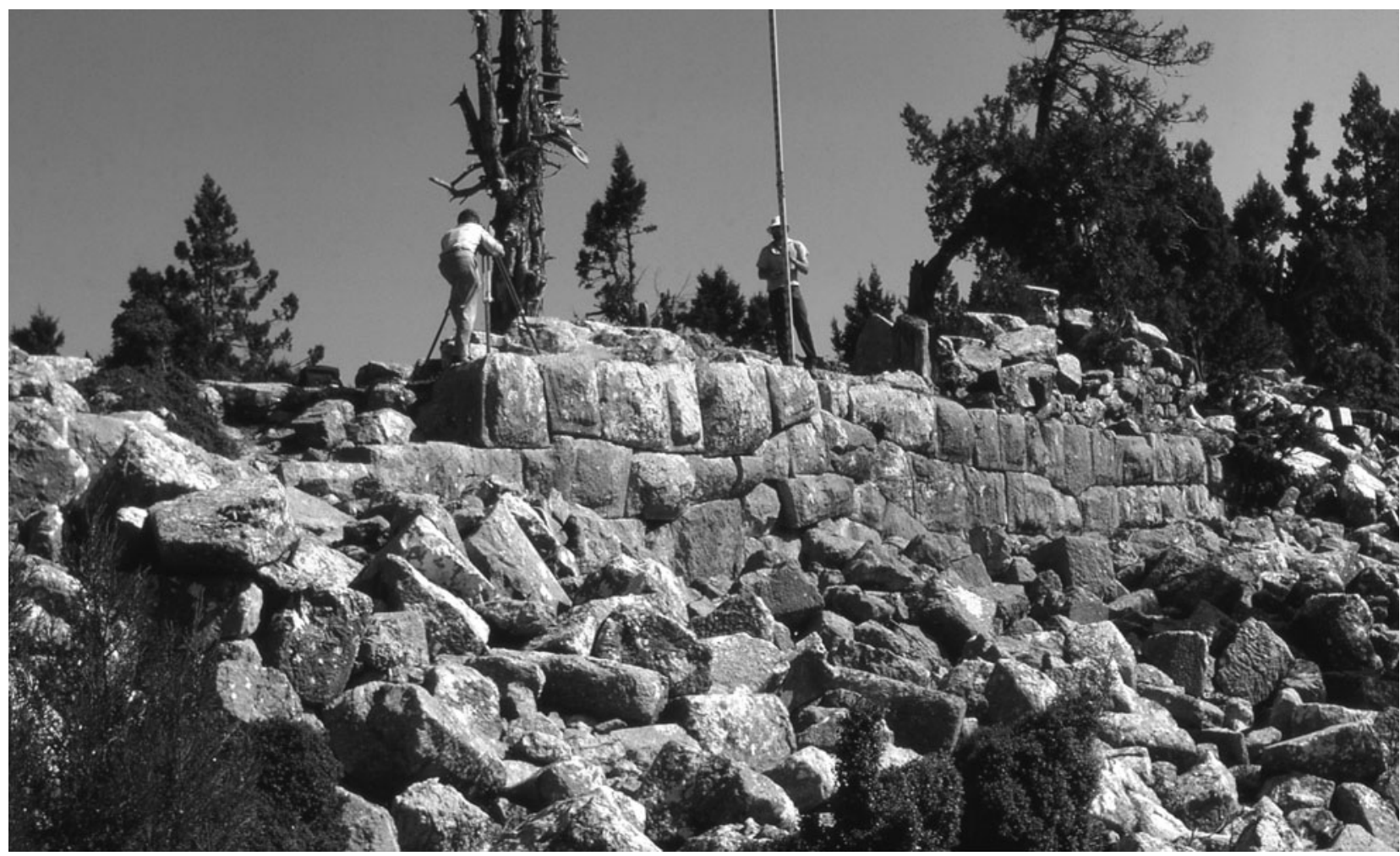

Fig. 34. Oinoanda, aqueduct south of the city, in 1981 (by A.S. Hall).

Imperial involvement in construction of civic baths and the business of building a Roman province

By the middle of the first century AD, then, thanks to the pax Romana that had created the right conditions for the settlement of Italians in the eastern Mediterranean, Hellenistic civilisation in Asia Minor demanded the Roman bathing habit (Coulton 1987: 72-84; 2012: 1.160), fused with the Greek gymnasium. The attitude of the Roman authorities administering the provinces was, it appears, supportive. The provincials were not all forced to wait indefinitely for the profits of a more vigorous economic life to accrue to their own civic treasuries before they might be permitted to build themselves a share in the Italian-style amenities they craved. Assistance of various kinds was available, so that some expensive public-building projects were even funded, at least in part, by the imperial authorities and could not have been completed with local funding alone. Besides probably isolated examples of Roman finance by imperial gift, however, it more often took Roman administrative intervention to rescue schemes that had been begun by the cities but had become mired in corruption, or to prevent them falling into the same.

While it is evidently untrue that but for Roman expertise the cities would have been unable to provide baths and aqueducts for themselves - in their correspondence about the administration of the Black Sea province of Bithynia et Pontus in AD 110-113, for instance, the emperor Trajan repeatedly tells the governor, Pliny, that the Greeks have architects too - it appears that often the real reason for a provincial governor to request from Rome engineers, quantity surveyors and the like for civic building schemes was the suspected dishonesty of the local consultants. Pliny's role in Bithynia was not just that of an encourager and adviser; as an imperial legate with Roman jurisdiction coupled with a strongly paternalistic ethos he was the personal embodiment of a central legal and political power that could not be ignored (Pliny Epistulae 10.17A/B-18), although legates might be duped or bribed on occasion. Generally speaking, the enforcement of legal contracts, the protection of public assets and funds, and the suppression of corruption played an important role in managing the success of the cities' costly public-building developments. Without this layer of Roman judicial and gubernatorial oversight, in combination with the fiscal oversight of the Roman procurator for the relevant region, under the prevailing conditions of weak, unaccountable civic government, it is likely that many of these amenities would never have reached fruition.

The concentration of building activity in LyciaPamphylia which is recorded in inscriptions as dedicated to, constructed by or even financed by the Flavian dynasty is notable (Kreiler 1975: 117-18, 101-02). Among them is a number of references also to buildings being 'repaired' or 'rebuilt', in some cases as a result of earthquake damage (İşkan-Işı1k et al. 2008: 115). Clearly, therefore, some of the structures had a pre-Flavian origin. To take only baths 
and related structures, at Kadyanda, Vespasian explicitly paid for the baths constructed there (TAM 2.651; IGR 3.507); the use of the gentilicium 'Flavius' indicates a date at the beginning of his reign, so this occured under Sex. Marcius Priscus' governorship (Eck 2000: 652; İplikçioğlu 2008: 11). Ten years later, at Olympos, T. Aurelius Quietus oversaw 'through his $\pi \rho$ óvor $\alpha$ ' (care) the reconstruction of the 'great' baths, possibly financed by Vespasian as his name appears in the nominative case, to add to or replace baths that had themselves been rebuilt $\delta i \dot{\alpha} \tau \tilde{\varsigma} \varsigma \pi \rho o v o i ́ \alpha$, 'through the care of', Priscus (SEG 56.1763, 1762; AE 2006: 1511, 1512; İplikçioğlu 2006: 75-81). At Patara, Vespasian is proclaimed as the builder of the baths, with their adornments and plunge-pools, dió, 'through the agency of', Sex. Marcius Priscus, but financed with funds raised by the Lycian League and funds from the city of Patara (SEG 57.1671; AE 2008: 1445). Eck has convincingly deciphered the lacuna in this inscription to record its original builder as Nero, $\delta$ ió, 'through the agency of', the same Priscus, dated AD 64-65 (Eck 2008: 269-75). Thus Patara and Olympos both had pre-Flavian baths. Kadyanda's appear as an innovation in that city provided by the first Flavian emperor.

At Perge, in Pamphylia, an early Flavian dedication appears in Latin for Imp. T. Fl. |Vespasiano | Caesari Aug. inscribed by the 'Roman citizens and the Council and People of the Pergaians' (I.Perge 54) on what resembles a building inscription like three others recording private donations, all from the South Baths (I.Perge 55, 60, 61). Eck (2000: 650-55) interprets this however as a plaque for an equestrian statue rededicated to Vespasian weeks after his acclamation as Caesar in AD 69; the statue stood in the baths. In either case, however, the dating shows that the baths were already under construction or in use under Nero.

L. Luscius Ocrea was the governor who, together with the procurator C. Pompeius Planta, oversaw the locally financed construction by the People of Balboura of an aqueduct dedicated to the Flavian imperial family, ca AD 74-76, which is associated with a baths building at its endpoint (SEG 28.1218; AE 1978: 804; Milner 2012: 83 no. 1 ; IGR 3.466). This was an innovation led by the city, but not achieved without Roman involvement. The Flavian imperial officials named in the inscription after $\delta i \alpha$, 'through the agency of', are not mentioned because they happened to be in office at the time, but because they were partly responsible for the building by the exercise of their office. A very similar building dedication to the Flavian family and the People of the Sidetans is found at Side in Pamphylia, under the same governor and procurator (I.Side 34), where the building is unidentified.

At Simena, the Council and People of the sympolity of Aperlai constructed the baths and prostoon (portico) dedicated to Vespasian's son, Titus, દ̇đí, 'during/under' the governorship of T. Aurelius Quietus and procuratorship of C. Vienius Longus, ca AD $80(I G R 3.690+1523)$. From the parallels cited above, we may think that the role of the Roman authorities in this case was no different from cases in which the reference to the governor and procurator was expressed by $\delta i \alpha$. That it is not a dating formula is to be inferred from the mention of the procurator, the emperor's financial chief in the relevant group of provinces, as well as the governor, the emperor's judicial and political chief in the province; their relevance is acknowledged in their being commemorated by name on the building, though the nature of their involvement, being familiar to all concerned, did not need to be stated.

At Delikkemer, outside Patara, in the aqueduct inscriptions the variation of prepositions referring to the role of provincial governors in starting and finishing the aqueducts is interesting (SEG 57.1673; AE 2007: 1519 ab). The original works were started vं ó, 'by', Villius Flaccus, but finished غ̇ंí, 'in the time of/under', Eprius Marcellus, both governors of Lycia during the reign of the emperor Claudius. It may be asked wherein lies the difference of role undertaken by the two governors. Perhaps Flaccus, like Pliny at Sinope (Epistulae 10.90-91), instigated the aqueduct. It seems likely, however, that all Roman governors were inevitably, in the exercise of the Roman jurisdiction, interested in a major public-building project in their province, so that the last-named governor, Eprius Marcellus, whose involvement is rendered by the word ė $\pi$ í, was acting ex officio, supervising and inspecting the work, as the Roman jurist Ulpian states at a later period (see below). Hence his name too was inscribed on the building for this reason. The inscriptions inform us that the aqueduct was then rebuilt after earthquake damage with a new additional pipeline by the emperor Vespasian, acting $\delta$ ió, 'through', his legate the governor Priscus, but using monies collected by the Lycian League and the city of Patara, in the latter case the city's share of what was presumably the Roman $\kappa \varepsilon \varphi \alpha ́ \lambda \alpha$ ov, i.e. tributum capitis, 'poll-tax'. Again, Pliny in Bithynia can be cited for examples of governors safeguarding the collection and application of locally raised sums of money (for example Epistulae 10.90-91). Controlling the finances was one of the highest responsibilities in managing such projects, and points to a main focus of the Roman involvement; but note, moreover, that the Roman state was donating part of its own revenue for this project (compare İşkan-Işik et al. 2008: 118).

Some projects were evidently conceived on a wider scale than the civic, as infrastructure for the benefit of people generally, in the shape of roads, bridges and lighthouses. These were declared to be imperial initiatives. In Lycia's case this began right from annexation in AD 43, as can be seen from the extensive province-wide road 
network, provided by the emperor Claudius, but in the construction of which the first governor, Q. Veranius, was the agent. The construction of the road network was a momentous event that was commemorated with a $6 \mathrm{~m}$-high pillar-monument at Patara, perhaps a base for an imperial statue, that was inscribed with a multitude of routes and distances (Şahin, Adak 2007; SEG 51.1832; 57.1670), and further by a large altar-monument on the pass at Kaklik on Bonda Tepesi between Myra and Limyra, both dated AD 45-46 and dedicated by the 'grateful Lycians' to the emperor Claudius (SEG 52.1438; AE 2002: 1472; Marksteiner, Wörrle 2002: 545-69, observing at 562 that that at Kaklık would have been only one of several such monuments). The works were still continuing under Eprius Marcellus, as illustrated by the bridge at Oinoanda dated AD 50 (AE 1998: 1399). Similar works were undertaken in Pamphylia under Firmus; see for instance the bridge at Döşeme which may well be dated, like the inscribed altarmonument beside it, to the road-building works of AD 72 along the via Sebaste (Adak, Wilson 2012: 3-4).

Analogous to road building is the pair of lighthouses at Patara built by Nero acting by Sex. Marcius Priscus in AD 64-65 'for the safety of those sailing in ships' (SEG 57.1672A, 1672B; $A E$ 2008: 1446, 1447). H. İşkan-Işı and colleagues (2008: 110-11) suggest that the city of Patara and the Lycian League may have paid for the lighthouses, like the aqueduct and the baths. The inscriptions for the surviving ruined lighthouse and accompanying statue base of Priscus proclaim that the initiative was entirely Roman, as 'Nero built it' and 'Priscus constructed them'. For all that, as imperial roads were regularly built or at any rate maintained at the charge of the cities through whose territories they passed (Jones 1940: 140-41), some local funding is most likely for lighthouses, too, perhaps supplemented again by the product of Roman taxes levied locally.

The Digesta 16.7.1 excerpts book 2 of Ulpian De officio proconsulis, in which the Severan jurist outlines the governor's duties to inspect public-building projects with special reference to their completion, their budgets in comparison with local resources and the effectiveness of their curatorship; in case of need the use of Roman army services could be supplied. From the evidence of Pliny's correspondence, the duties described by Ulpian seem to have been rather similar to what we find a century earlier. Retrojecting the literary evidence further back in time enables us to shed light on similar actions in first-century Lycia attested in contemporary inscriptions. As we have seen, Roman involvement is demonstrated in what were probably mostly locally conceived schemes to introduce baths and improve the water-supply in various Lycian cities. Such involvement can, from an historian's perspective, also be seen as promoting or facilitating the amenities of civilisation (Macmullen 1959: 214-16; Mitchell 1987:
338, 346-47, 352-53); but to what extent, in the Hellenistic east, did the pre-existing city-based culture negotiate with and tailor the impact of Rome to its own needs?

Compare the situation in a backward province like Britannia, where the Romans introduced city-based culture itself. Writing about the Flavian administration of Britannia under Gnaeus Iulius Agricola, the Roman senatorial historian Tacitus describes 'most salubrious schemes', actually a course of the most ambitious social engineering, whereby the Romans tamed the, in their eyes, primitive savagery of the Britanni by getting them to build and settle in cities, with the governor's private exhortation and public assistance, until the process, reinforced by Roman rewards and punishments, gained its own momentum and the provincials were freely adopting Roman culture with its competition for honour and Latin rhetorical education. In the final stages, we are told, they took to wearing Roman fashions and gradually adopted the delenimenta vitiorum, 'temptations to vice' - porticus et balineas et conviviorum elegantiam, 'porticoes and bathhouses and sophisticated banqueting' (Tacitus Agricola 21). To the cynical Tacitus, the provincials were in this way brought to collaborate in their own enslavement, though on his own showing that was not how it looked to the philo-Roman Britanni who eagerly took to the new civilisation. We can conclude at any rate that, whatever else they did, the new cities acquired Roman-style thermae, heated bathing establishments that were indeed equipped with porticoes, plunge-pools and banqueting halls; but what is extremely interesting is that this was the result of saluberrimis consiliis, that is to say, deliberate policy by the Roman administrators of a province that was annexed in the same year as Lycia, AD 43. The Romans did not invent the concept of the classical city that was the basic unit of their civilisation, but they did seek to propagate it, and they sought to exercise political control over the cities by supporting pro-Roman elites wherever they could. This led to permanent political changes in provincial societies.

In Lycia, a land of semi-autonomous city-states that in the middle of the Hellenistic period had formed a

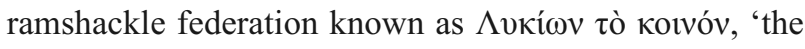
Lycian League', we hear that the population was by the early AD 40s in turmoil - law and order had broken down and brigandage had spread, leading to the deaths of some Roman citizens. The ineffectual unreformed League looms large in the background circumstances to the inscribed dossier of Lycian decrees found at Corinth in honour of Iunia Theodora, a grand Roman hostess and benefactress of the Lycians who was a prominent resident there ( $S E G$ $18.143 ; 22.232 ; 23.176)$. These include references to the

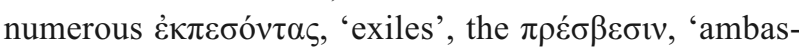
sadors', sent by the League and individually by Lycian cities, and her intercessions on the Lycians' behalf with 


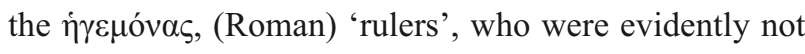
yet represented by a governor on the spot. All these seem best attributed to the tumultuous events just before the birth of the province (see Wörrle 1988: 97 n.100; Behrwald 2000: 206; Jones 2001: 166-67; Winter 2003: 183-93, especially 188). The absence of the boule from the inscribed letter of the League and its chief magistrates addressed to the archontes, boule and demos of the Corinthians (SEG 18.143, lines 42-69) strongly supports a date before Veranius' reforms.

\section{Political reforms on annexation of the province of} Lycia, AD 43

The Lycian civil war and murder of Romans provided the occasion for annexation, and one of the first tasks of the new governor, Q. Veranius, was to pacify the province by defeating the 'brigands' (conceivably a prejudicial description of the losing faction in the civil strife; see Kokkinia 2004: 47-48). To the ancient literary sources for this is now added the stadiasmus inscription from Patara, on a tall pillar-monument dated AD 45-46, mainly listing the distances between places in Lycia, but also praising the emperor Claudius for his intervention (SEG 51.1832=AE 2001: 1931-32; Suetonius Claudius 25.9; Cassius Dio 60.17.3-4; Jones 2001: 161-68). The stadiasmus inscription, which is explicitly a dedication of the 'Lycians' to the emperor, $\sigma \omega \tau \tilde{\eta} \rho[1 \tau]$ ov $\mid \dot{\varepsilon} \alpha v \tau \tilde{\omega} \nu$ है $\theta v o v \varsigma$, 'saviour of their nation/League' (the object of the dedication may have been a statue on the top), tells us at side ' $\mathrm{A}$ ' in abstract, political terms that the foremost thing done after the restoration of peace and orderly government, namely the creation of a new constitution for the Lycian League, ensured that the general assembly of delegates from each city was subordinated to a new council of the elite. We do not know in detail how it was done (though we can make a plausible conjecture in principle, see below), but the result was a boule, stuffed with the most politically-reliable

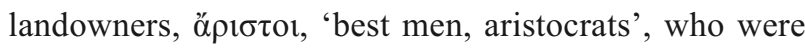
'selected', i.e. picked by a controlling mechanism no doubt approved by the legate, Q. Veranius (Marksteiner, Wörrle 2002: 563-64).

The reform was permanent, and the League was transformed into a provincial council, and yet it was different from other provincial councils, in that none of them is known to have had a boule and ekklesia, in a bi-cameral structure (Deininger 1965: 73-81; Balland 1981: 182-85; Behrwald 2000: 188-209; Marksteiner, Wörrle 2002: 563 64). It seems appropriate in this place to suggest a supplement for the stadiasmus inscription's lacuna in A 30-31. With C.P. Jones' convincing syntax (Jones 2001: 163) and M. Wörrle's reading of line 31 after the comma (Marksteiner, Wörrle 2002: 564 n.65), if we adapt SEG 51.1832, lines 25 to end will run as follows:

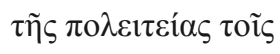

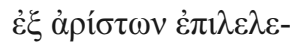

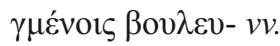

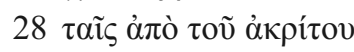

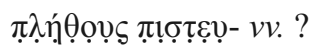

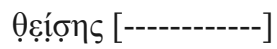

$\ldots \Sigma, \dot{v} \pi[\grave{\varepsilon} \rho \tilde{\omega} v \varepsilon \dot{\varepsilon} \varepsilon \rho \gamma \varepsilon]-$

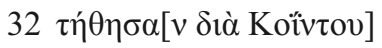

Oỏn $\rho \alpha[$ [íov $\pi \rho \varepsilon \sigma \beta \varepsilon v]-$

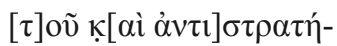

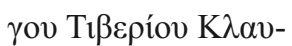

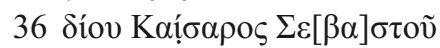

There are two good photographs published of the relevant block, 24 A VIII (Işık et al. 1998/1999: Taf. 19(b); Şahin, Adak 2007: 33). The adjacent stone carrying the second half of lines 30-33 is missing. Both photographs show that the stone carrying the first half of lines 30-33 has room for about two letters before sigma in line 31 , where two is more likely than three, as the inscription consistently leaves a margin of about half a letter's width on the left and the sigma is placed under and slightly left of the first sigma in line 30 , which is preceded by three letters including iota. What is more, the surface of the stone to the left has been stripped by fire damage, but not so deeply that some of the grooves for the original letters cannot still be made out. In line 31 it is clear that the letter before sigma has a horizontal hasta at the top, and there are traces of a vertical to the left and of a horizontal in the middle. Eta is excluded, as is any circular letter. Before sigma, it can only be epsilon.

Benet Salway, who earlier concluded independently that we should read epsilon, preceded by one letter, has suggested in an unpublished paper to read a nominative plural participle, in agreement with $\Lambda$ v́к10 and the two preceding participles $\dot{\alpha} \pi \alpha \lambda \mid \lambda \alpha \gamma[\dot{\varepsilon}] v[\tau \varepsilon] \varsigma$ and $\dot{\alpha} \mid \pi \varepsilon 1 \lambda \eta[\varphi]$ ó $\tau \varepsilon \varsigma$

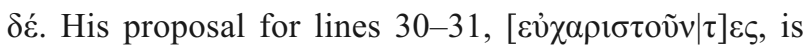
probably too long here, and $[\chi \alpha \rho \imath \theta \theta \dot{\varepsilon} v \mid \tau] \varepsilon \varsigma$, which was suggested as a solution to the problem of length at Joyce Reynolds' Epigraphic Saturday in Cambridge in January 2007, does not have the required meaning, 'in gratitude', but instead means 'having been granted' (see LSJ s.v.). In fact, no participle is required to obtain the meaning, 'in gratitude', which is implicit in $v \pi \varepsilon \dot{\rho} \rho+$ genitive (see LSJ

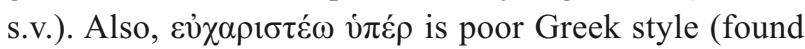
however in Caria: I.Stratonikeia 2.1, 1113, 1119); غ̇ंí or $\pi \varepsilon \rho i$ were preferred with this verb (LSJ s.v.). Finally, a

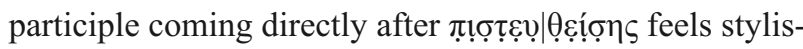
tically awkward and would spoil the balance of the sentence, which was designed with an unexpressed finite

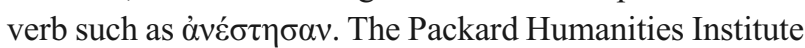

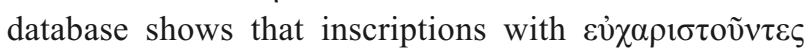
almost always use it to support an expressed main verb. 
SEG 52.1438 = AE 2002: 1472 (Kaklık), which is a close cousin of our text, does have $\varepsilon \dot{v}[\chi] \alpha \rho ı \sigma \tau o \tilde{v} \tau \varepsilon \varsigma \mid \pi \varepsilon \rho \grave{~ \tau \eta ̃ \varsigma ~}$

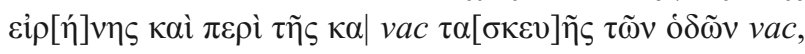
without an expressed main verb, 'in gratitude both for the peace and for the construction of the roads', but that text is free from the other stylistic objections noted above.

A better solution is to take the word as a neuter adjective, of the same type as $\dot{\alpha} \lambda \eta \theta \dot{\eta} \varsigma,-\theta \dot{\varepsilon} \varsigma$. Before the epsilon, there is but one letter to find. The first photograph suggests the curved upper arm of kappa, but the rest of the letter is indistinct. By contrast, the second photograph, which was taken at a different time with the light coming from another angle, shows the lower diagonal arm of kappa, the angle of which is too low for lambda or alpha. Again, the rest of the letter is indistinct. Because neither photograph shows both arms at the same time, however, it will be appropriate to suspend belief and print kappa in square brackets.

There is no neuter noun in the vicinity to which such an adjective could be attributed; so we need an adverbial phrase with up to 10 letters in the missing part of line 30 as in the identical lacuna in line 31 , and here [Eiç tò $\delta \eta \eta \varepsilon \mid \kappa] . \varepsilon ́ s$, 'in perpetuity, permanently', seems a possibility (see LSJ s.v. for references, of which the nearest in date is [S. Paul] Epistle to the Hebrews 7.3, from the second half of the first century AD: Barton, Muddiman 2001: 1236). The constitutional reform, like all such, was intended to be permanent, and it would be natural for the text to mention it in proximity to the operative word

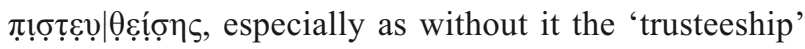
could have been felt as temporary.

On the same occasion, Benet Salway proposed to read [غ̇ंí], 'in the time of', after a mese in line 32, for which compare $S E G 52.1438$ (Kaklık). This is a persuasive

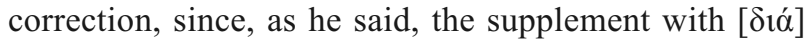
would not have required the repetition of Claudius' titulature at the end of what would have been the same sentence,

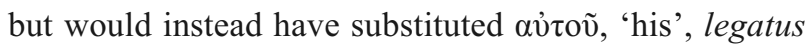
pro praetore, as in $A E$ 2005: 1498 (Gagai).

The result is that we have a genitive absolute from line 25 to the comma in 31 which picks out for special mention a constitutional reform to the League. The Lycian League who set up the monument (Kokkinia 2004: 47) described

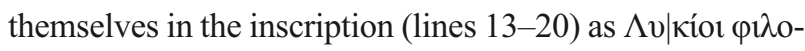

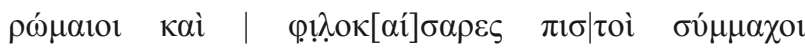

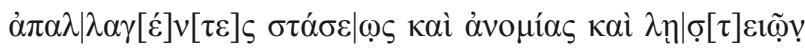

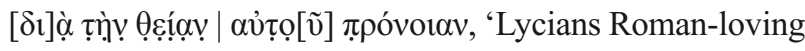
and Caesar-loving, loyal allies, freed from faction and disorder and brigandage thanks to his (Claudius') divine providence'. The genitive absolute is a circumstantial clause, which elaborates upon the Lycians' strongly asserted recovery of their 'concord, the equal administration of justice, and the ancestral laws' (lines 18-24 of the text:

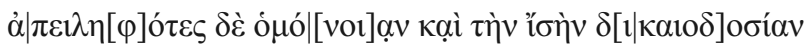

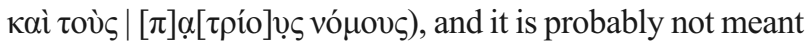
to be felt as non-committal as to the connection of thought. The matter was far too important for casual mention, and must surely be meant for an illustration. The constitutional reform was held out as a key element in the restoration of the 'ancestral laws' in particular, and the Lycian League was proud of it. Nevertheless, we know from another dedication to Claudius at Gagai that Veranius was behind moves to set up boulai in Lycian cities, and according to the evidence of the stadiasmus inscription, as the instrument of Claudius' 'divine providence' whereby the Lycians got back their law and order, one infers that he was the sponsor of a similar reform at the League too (SEG 50.1350; 51.1824 bis; AE 2005: 1498; Marksteiner, Wörrle 2002: 563-64; Schuler, Zimmermann 2012: 615-17).

Commentators have disagreed as to the construction of the clause. The interpretation of C. Kokkinia, which is based on a detailed study of the language using ancient parallels, assists us to approach what is proposed here. She translates, 'the conduct of affairs having been entrusted to the distinguished councillors, set apart from the promiscuous crowd' (Kokkinia 2004: 45-46 n.27). The parallels she cites from Plutarch Pericles 11.2 and Theseus 25.1-2 show a comparable and relevant emphasis on constitutional reform by way of identification and separation of an elite order from a larger political element, the 'many', and on giving the elite order an equivalent or preponderant weighting.

Whereas Kokkinia paraphrases $\dot{\varepsilon} \xi \quad \dot{\alpha} \rho \dot{\sigma} \sigma \tau \omega v$

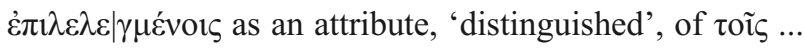

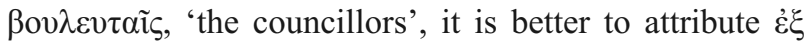

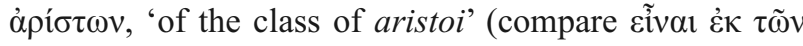
$\delta v v \alpha \mu \varepsilon ́ v \omega v$, 'to be one of the wealthy': Plato Gorgias 525e),

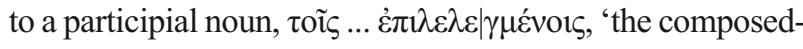
of-aristoi selected ones'. The verbal element of the parti-

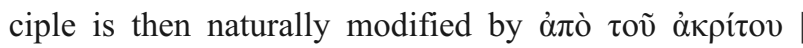

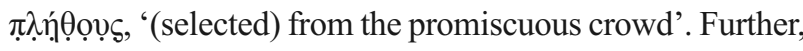

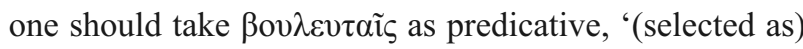
councillors', and so not the subject of the participle.

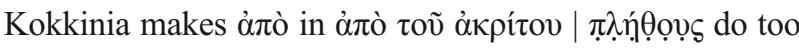
much work to mean by itself 'set apart from the promiscuous crowd'. For this to be convincing, either another participle such as $\dot{\alpha} \pi \circ \kappa \rho \imath \varepsilon \varepsilon \tilde{\tau} \sigma \iota$, 'set apart', or a different preposition, such as $\chi \omega$ pís, would have been necessary.

Then, since $\pi \lambda$ ṇọọ, 'crowd', can also mean 'commons', 'assembly' or 'mass, main body', it may be preferable to translate it to suit the context in one of its technical, constitutional senses; àkpítov, 'promiscuous, undifferentiated, unselected', leads naturally to the translation, 'general assembly, general mass'. See more on this below.

One might translate from line 25 therefore as follows: 'the conduct of affairs having been entrusted [perma- 
nently] to the members of the aristocracy selected as councillors from the mass of the delegates (or "the general assembly"), the Lycians (= Lycian League) (dedicated it) as a thank-offering for the benefits they had received. In the governorship of Quintus Veranius, legatus pro praetore of Tiberius Claudius Caesar Augustus'.

If Veranius had personally selected on a whim some aristocrats and not others for the council, he would probably have restarted the civil war. The standard ancient procedure in establishing a constitution was to adopt a census qualification as an independent and essentially unarguable arbiter of political status. This is what Plutarch, writing in the first quarter of the second century $\mathrm{AD}$, has Theseus do in a prehistoric Athens, in the case cited above. Jones (2001: 168) is likely to be right to suggest this is what Veranius did in Lycia. Those eligible for selection as councillors would have to be above a certain property census, in fact, by analogy with the Roman senate, the highest census. The stadiasmos inscription might suggest that that class was named aristoi, except that the epithet lacks the definite article. More likely, therefore, it was an informal term.

Since the League was (at any rate in the second century AD) of an order of magnitude of about 2,000 persons (Behrwald 2000: 195), Veranius needed them to choose a portion of their number without risking accusations of partisanship, favouritism or prejudice, men who would feel honoured to be elevated to the new boule and who would be tolerated in the exercise of their powers by the unselected residue. The League would therefore adopt a property census to define the desired rank of eligible men from whom to select the council. How the actual selection from the class of aristo $i$ was made is a matter of speculation. In order to work, the method had to be acceptable to the Lycians and the selected men had to be respected by them. Given the recent civil strife, anything involving election from a list would seem fraught with hazard, yet maybe that could be allowed to happen under a rule controlling nominations that was agreeable to both Veranius and the League. It is not likely that all the aristoi from the plenum were selected, for that would have pitted the boule against the ekklesia.

The League's constitutional authority would not have been overtly undermined by the change to a bi-cameral structure; but the council's probouleutic function could be relied on to control the business of the assembly in future. Presumably, no decrees could become law without the council's approval. The Roman authorities needed a compliant council, something much easier to achieve with a boule to control the business of the 2,000-strong assembly.

Other commentators have argued for less easy constructions of the above-mentioned clause. Where Jones (2001: 167) translates, 'the conduct of affairs [had] been entrusted to councillors selected from superior people by the incompetent majority', he relies on an unusual use of

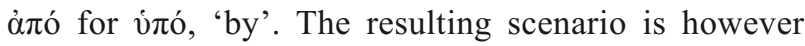
undermined by the evidence from Gagai cited above: Veranius was the agent responsible for controlling the process of selection of the councillors in the cities, and would not have been less vigilant at the Lycian League (Schuler, Zimmermann 2012: 615-17). Also, if ả vं ó, 'by', went with 'entrusted', thus 'entrusted by the incompetent majority', the reform is still presented in the earlier part of the stadiasmus inscription as due to Claudius' 'divine providence', not a self-reformation by the Lycians, and it is very hard to believe that an assembly described as 'the incompetent majority' would have been able validly to vote away its authority to the council or that there would have been any point in mentioning such an act in an inscription (compare Marksteiner, Wörrle 2002: 564).

T. Marksteiner and M. Wörrle (2002: 564) take ỏ ó another way, as a point de départ for the process of the conduct of affairs having been entrusted from the assembly to the council. Yet Wörrle states that the reform consisted of the formation of a boule of Lycians; the Bundesversammlung (general assembly), continued to function, but under the political control of the boule. This analysis of the reform is clearly right, but it is surely unthinkable that the League would set up an inscription explicitly stating that the effect of the new creation was that the politeia was taken away from the assembly and put in the hands of the boule. If it had been done in that way, it would have left the assembly overtly stripped of its historic powers and reduced to a shell. This seems an unfeasibly blunt insult to a Lycian nation who had recently been waging war over their respective rights, with whom the Romans were working to build a province not won by military conquest but annexed in a peace-keeping operation, although of course their annexation was forever.

M. Sève has pointed out that the use of the passive

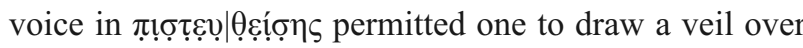
the imperial intervention ( $A E$ 2001: 1931/1932). In fact, the sentence is quite specific; the 'entrusting' of the conduct of affairs was the purpose and the result of the creation of a boule with probouleutic powers. The reform was one in which the assembly participated probably voluntarily; the pre-existing assembly of delegates, who provided the personnel for the boule, continued to meet and function. It involved an extension of their honour, not an abridgment, to have a boule. They were happy to entrust the politeia to their own elite. The inscription set up by the Lycian League gives no grounds to conclude that Veranius needed to apply continuous force to push the reform through, although he was, no doubt, the ultimate author, in Claudius' name, of the reform. 
The language of $\pi i ́ \sigma \tau \iota \zeta$, 'trust', is suggestive. It occurs especially in Hellenistic decrees appointing judicial committees from one city-state to decide cases in another. So, for example, Daux 1975: 37-38 (Larissa, lines 11-13):

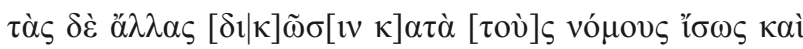

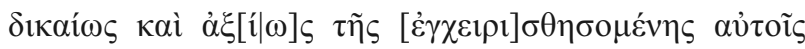
$\pi i \sigma \tau[\varepsilon \omega \varsigma$-----], 'and the other law-suits they will judge according to the laws equally and justly and worthily of the trust that will be placed in their hands ...'. On that occasion the judges were coming from Teos to Larissa, to decide cases there according to the laws of Larissa. Compare similar material from Myndos (SEG 58.1225). The Lycians could therefore represent, at the moment of its creation, that the boule of the Lycian League was to hold in trust the existing powers of the federal institution, which were not being undermined but placed in the internal, trusted hands of men of the highest class and selected from the best men among them, the better to carry out the unaltered purposes of the League.

The proclaimed restoration of order thanks to Roman intervention, by way of a 'return' to an 'ancestral' political system after a period of extreme civil strife was probably propagandistic. The upshot of what happened appears to chime with the lex Pompeia that provided for the Roman settlement of Bithynia, namely that one faction - the 'wealthy classes' - was enabled to prevail (Jones 2001: 166-68; Kokkinia 2004: 45-48). It is not known whether the Lycian League at any time previously had a boule. The 'wealthy classes' were clearly represented by the aristoi, the chief beneficiaries of the constitutional reform.

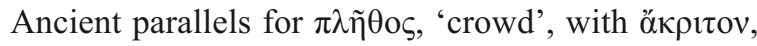
'promiscuous', contrasted with select or superior men, are clearly pejorative to the former (see Kokkinia 2004: 4546 n.27 and references including Plutarch Pericles 11.2 and Theseus 25.1-2, to which add Josephus Bellum Iudaicum 3.411). Not too much should be made of this,

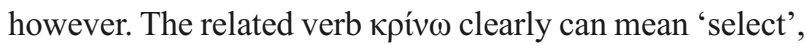
and $\kappa \rho \imath$ ó $\varsigma$ refers to 'selected' judges of contests and a 'select' group of mourners in Homer Odyssey 8.258 and Iliad 7.434. The 'promiscuous crowd' is necessarily in the unselected state. Socially motivated language in these terms was above all specific to the context of the formation of new constitutions. The control of writing and copying was generally in the hands of the upper classes, and our sources' aristocratic tendency comes out in passages discussing politics in particular. The Lycian League too was controlled by self-described aristocrats. Their habitual manner of speaking about politics was de haut en bas.

With what appears to be the political reality in view, modern scholars are tempted to assume that oligarchic victors in the civil strife were triumphing over their democratic enemies in the inscription, but one should probably resist the temptation here. To notice the reform of the
League in the inscription, it was sufficient to differentiate

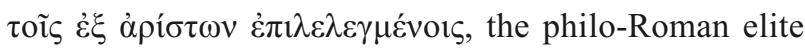
councillors, from the mass of delegates, as a 'selected'

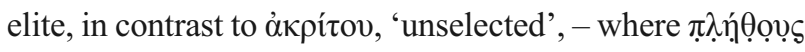
may have the constitutional meaning 'assembly, corporate body' (see LSJ s.v.), so that the translation 'general,

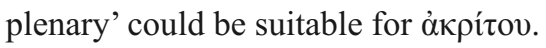

This $\pi \lambda \tilde{\eta} \theta$ o $\varsigma$ was normally referred to simply as the koinon; but since the reformed, bi-cameral body continued to be called the koinon, that term was not available in explaining the constitutional reform. The later term for the plenary body, archairesiake ekklesia, 'electoral assembly', which is attested many times in the second century, was not yet available either (Deininger 1965: 73).

An inscription dedicating a statue(?) to Claudius and celebrating his reforms and 'divine providence' is probably an unlikely place to expect to find Lycian political pointscoring. Of course, oligarchic prejudices among the newly elevated councillors towards anyone who could claim to support the demos are not inconceivable. In this case, however, the really contrasted terms are $\pi \lambda \tilde{\eta} \theta 0 \varsigma$, 'assembly', with $\beta$ ov $\lambda \varepsilon v \tau \alpha$ í, 'members of a boule', i.e. the point being made is more likely to be constitutional than partisan. It cannot make the slightest legal or political sense for the League to have set out to disparage in their inscription the source of the constitutional authority that had been honourably entrusted to the boule, their own general assembly. To do so would have undermined and, as it were, delegitimised themselves.

Since the delegates to the League will in any case have been members of the elite in their own cities (Behrwald 2000: 203-04), the promoted class was in fact a superelite, composed of the wealthiest, the most ardent Roman loyalists, men whose ambitions ran beyond the boundaries of the province, who - themselves or their sons - would learn some Latin, serve in the Roman army, for example as centurions, become aides to Roman governors, get Roman citizenship and in some cases hold Roman procuratorships. The protection of the class which was proudly supporting Claudius, so useful to Rome, would have been an intended result of the settlement imposed on Lycia in the lex provinciae (on which, see Wörrle 1988: 96-100). A general reform of the constitutions of Lycian cities in the matter of their boulai appears likely in this context (Schuler, Zimmermann 2012: 615-17). Q. Veranius' reforms were aimed at the creation of an Italian-style ordo decurionum, a 'curial class' of councillors, who would form an hereditary, oligarchic, pro-Roman, bouleutic class in every city (Lepke et al. 2015: 320-21).

Freed from the dangers of death or exile, Rome's most eager collaborators and their descendants were now to come in for a valuable reward, a relatively secure ascendancy in their cities which they could hold for generations. 
This brought with it successive opportunities to improve on their family's position at a provincial and imperial level through marriage alliances, office-holding, service in the army and so on. An important step upwards was becoming a Roman citizen. Provincial governors were instrumental in obtaining the Roman citizenship for Lycian notables. To select just two cases typical of what happened in virtually all the cities where sufficient epigraphic evidence survives, the Licinnii and the Marcii from Oinoanda took the gentilicia of Nero's legates C. Licinius Mucianus and Sex. Marcius Priscus. This probably cost a lot of money, though we do not hear about it. On the continued rise of members of such families who eventually joined the senatorial aristocracy, see, for instance, Deininger 1965: 80-81, 178-79 and Reitzenstein 2011: 126-27.

The cities from now on did their best to dispense with political change as a feature of their society. For most of the time, there was no longer any political advantage in supporting a democratic side to local politics, which accordingly disappears from the epigraphic evidence (Jones 2001: 166). What mattered now was how to manage the relationship with powerful Romans, who was the best connected, who knew how to play the system and the like. By and large, the new order did not stimulate others into opposing an all-powerful Rome - it was clearly futile to do so unless one was prepared to forsake the city-based culture altogether and join the 'brigands', those exiled from civilisation. The old politics had become obsolete (compare Thornton 2001: 427-46).

\section{Physical reconstruction of the province of Lycia}

Once Q. Veranius had settled the politics, the stadiasmus inscription (side 'B') tells us further that, acting in the name of Claudius, he launched what from the very comprehensive list of places and distances in the text appears to be an unprecedented, province-wide roadbuilding campaign, as indeed is stated there (ọ $\delta[0] v ่ \varsigma$

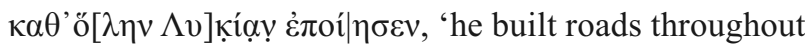
the whole of Lycia'). From other inscriptions too we know that there followed several decades of construction work, buildings as well as roads, including in many places aqueducts and bathhouses. It seems then likely that, as in Britannia, Roman support for these construction schemes was a result of policy which was followed by successive governors, and not a haphazard, unplanned response to isolated petitions from cities. Veranius had set about intervening militarily, with the suppression of the banditti, politically, with a lex provinciae and new constitutions for the cities and for the League, and materially, by building up infrastructure. The physical reconstruction supported the political. The outcome is that Lycia's Hellenistic past largely disappears under the impressive material remains of the new imperial civilisa- tion, which was not just about buildings. The new bathsgymnasia too were the setting for imperial sacrifices and banquets, and presumably for competitions in honour of emperors, to whom the buildings were typically dedicated (Milner 2015: 193). We see also that venerable political structures such as the Lycian League were completely remodelled and given new political and religious outlooks. This led to new purposes, not least the organisation of the imperial cult (compare Reitzenstein 2011: 35-38). Indeed, the imperial cult, with its elite priesthoods, ceremonies and festivals in which rich benefactors gave lavish entertainments, banquets and monetary largesses to various categories of the people, appears to have been a crucial element in bringing about a social revolution to form an imperial aristocracy (Lepke et al. 2015: 338-40).

Thus the Roman treatment of Lycia had much the same broadly political ends as in Britannia, despite the great difference in their level of civilisation. In both provinces Rome's imposition of peace under Roman law, the better to advance Roman civilisation as they understood it, had for its aim a peaceful country settled by lawabiding citizens who lived in cities organised on the Roman model, worshipping, professing loyalty to and paying taxes to the emperors. In Britannia the cities were built de novo; in Lycia they were redeveloped. In both provinces the provincials ended by paying the greater part of the costs of the construction works. But at the same time the Romans fully embraced the interests of the many rich and important provincials who collaborated with and helped Rome to put down roots in foreign soil. The part the elite played in transforming their own and their people's identity was crucially important. These families had every reason to look for the security of tenure that accompanied the Roman law of property. Belonging to the Empire supplied the executive power to enforce it. Becoming a Roman citizen was the best way to acquire Roman rights.

The policy seems to have been highly effective. Once the Graeco-Roman culture in Lycia was established, in some ways a revitalisation of the Hellenistic with an infusion of the Italian, in others a protected and stable legal, political and religious environment, more firmly fixed in comparison to what went before, it took on a vigorous life of its own but along apolitical lines. Political energies were transformed into a competition for honours voted by cities and by the League, and the cult of the emperors was eagerly absorbed in, fused with or added to traditional cults. This was expressed particularly in monumental public buildings, the elaborate sports contests and religious festivals that took place in and around them, which were organised both at the civic and the provincial levels, the largesses and distributions of money to 
audiences and spectators on such occasions and the adornment of their public spaces with an ever-growing forest of statues honouring athletes, agonothetes and founders, League officers and high-priests, Roman governors and emperors. Under the Flavians (AD 69-96), there was room for pioneering work by bringing bathsgymnasia and aqueducts to some more remote or lesssignificant parts of Lycia-Pamphylia, but other cities had by then fully imbibed the culture and needed help when earthquakes destroyed their buildings or they had outgrown them and needed bigger and better amenities. The system that had been set up on annexation in AD 43 was now in full swing. The involvement of the Flavian Roman authorities everywhere is apparent from numerous inscriptions, but to get an inside view we need to look elsewhere and to slightly later literary sources.

\section{Roman gubernatorial oversight of civic building}

In Bithynia-Pontus ca AD 110-113, the Roman authorities also directly engaged with the desire of provincial cities to construct or renew their public baths and aqueducts by providing practical assistance (Pliny Epistulae 10.17b-18, 23-24, 39-40, 70-71, 90-91). The purpose of Trajan's quip, gymnasiis indulgent Graeculi, 'the little Greeks do love their gymnasia' (Pliny Epistulae 10.40), was partly at least to deflect and disguise from himself and his correspondent their own excitement about such schemes, which might not be entirely in accordance with traditional ideas of Roman dignity. Like Tacitus, they affected to scorn the refinements of civilisation while themselves living a life of extreme sophistication and taking full advantage of it. There can be no doubt that they were entirely familiar with the most luxurious bathing and banqueting, and, for that matter, gymnasia. On the often contradictory Roman attitudes to Greek athletics, see Hallett 2005: 70-75. Pliny himself could strongly condemn gymnastic contests in Gaul and Rome (Epistulae 4.22.7).

In reality, the Roman upper classes delighted in the opportunities for prestige offered by imperial rule in the competition for honour with fellow aristocrats. That they became involved in provincial public building because they were responsible for relevant duties imposed on them by the Roman jurisdiction should not blind us to what looks like a readiness to take part in a political game of money and power.

The emperor was placed above the governors and yet owing to his physical remoteness was at risk of being upstaged by them. He and his family needed to take credit for publicly-funded buildings erected under the auspices of the Roman authorities a thousand miles from Rome, while keeping a close watch to ensure that governors on the ground did not keep for themselves the honours more directly due to the creators and sponsors of the buildings.
The governors on the other hand wanted to be honoured and celebrated by grateful provincials to reflect credit on their political status in the senate, in Rome and the Empire, the better to expand their power-base and, not least, further to enrich themselves and their families.

One of the ways the emperors could exert control was by legislation to prevent the names of others being inscribed on public monuments (Digesta 50.10 .3 (2): Inscribi autem nomen operi publico alterius quam principis aut eius, cuius pecunia id opus factum sit, non licet, "it is not permitted to inscribe on a public building the name of a person other than the emperor or whoever paid for the work'). This jealousy must be one of the reasons that so many buildings had to be dedicated to the emperor, along with emperor-worship and the imperial cult, imperial permission and oversight, and other assistance direct and indirect. Another method of control was the system of imperial approval of publicly-funded schemes, which presupposed the possibility of refusal (Digesta 50.10 .3 (1): Publico vero sumptu opus novum sine principis auctoritate fieri non licere constitutionibus declaratur, 'it is made clear by imperial laws that it is not permitted for a publicly-funded new building to be built without the sanction of the emperor'). There is no reason to think that these laws cited by Aemilius Macer de officio praesidis, 'On the office of governor', in the third century $\mathrm{AD}$ were new in his time.

From Trajan, who emerges from Pliny's correspondence as unfailingly wise and reasonable, the Greeks would not get permission unless a scheme was judged within the scale of their resources - quod possit illis sufficere. It was not politic to be associated with failed grands projets and bankrupted communities. Like a providential deity, the emperor was there precisely to decide what was good enough and costly enough, to accommodate the needs of the cities. That he would wish to accommodate them if possible, however, seems to be implicit in the relationship. The glory of having public buildings dedicated to oneself or otherwise having one's name and titles celebrated in public inscriptions was extremely desirable to the emperor. After imperial indulgentia, 'permission', for a scheme of a given size and scope with a matching budget, for which governors and patrons had interceded on behalf of cities, conscientious governors such as Pliny continued to be involved in overseeing the public-building projects apparently in some detail, assisting in the collection and safeguarding of funds and procuring architects and engineers. With the emperor's support, they might also be permitted to adopt or even instigate projects, such as Pliny's plan to revive a longstanding local ambition to complete a canal at Nikomedeia (Epistulae 10.41-42, 61-62, 90-91; on Pliny in Bithynia, see further Mitchell 1993: 1.212). 


\section{Concluding remarks}

It is clear, then, that there was a considerable expansion of building activity in Lycian cities after the formation of the province, which continued over a number of decades. There is some evidence that the initial stimulus was provided by the Romans, as witness the road network and the first aqueduct at Delikkemer. The process, which was supported by local and sometimes imperial funding, soon developed a strong momentum of its own, in a country, after a history of internecine wars, revolutions and brigandage, seemingly able at last to enjoy peace and prosperity, though at the price of its political independence and freedom (compare Marksteiner, Wörrle 2002: 560; İşkanIşık et al. 2008: 115). The philo-Roman Lycian aristocracy would offer thanks for this to the Romans and their provincial governors and procurators, who protected them and with whom they could do business. While the Lycians' enthusiasm seems evident for so many of the monumental structures that changed the face of their cities for ever, the Roman government's involvement is everywhere honoured in the building inscriptions that were erected by the civic authorities even in very small cities. It thus appears that in many previously unpromising places political conditions were sufficiently improved for the collection and investment of funds and development on a grand scale to become possible again, or perhaps for the first time.

The process does not appear to have been interrupted but rather continued with renewed vigour following the Flavian dynasty's installation in the purple in AD 69. That the cities' high investment ran in the first instance to a proliferation of baths-gymnasia and wrestling schools demonstrates that the Lycians were able to initiate and lead on many of the schemes; the nature of the improvements was dictated by those pursuits that were most esteemed by the local pro-Roman elites who were now in control. But in doing this they probably were in tune with the local populace, who were usually funding the facilities, as well as quarrying the stones and building them. At the same time, the Roman authorities were quite ready to facilitate the Lycians' construction of aqueducts, baths and palaistras and associated institutions that were emblematic of the Graeco-Roman city, by providing care and oversight, possibly technical assistance and, on occasion, money. This cannot have been easy, given the small size of the provincial governor's officium, but the imperial system of managed politics required that they could not leave it to Lycians to manage major undertakings without Roman involvement either. Despite the faults of individuals such as the provincial governor Eprius Marcellus, who was prosecuted in AD 57, without success and resulting in their exile, by a determined delegation of the Lycian League in Rome, for bribery and corruption (Tacitus Annales 13.33; Deininger 1965: 77), the Romans in Lycia in this period generally appear more as patrons, supporters and enablers of provincial ambitions than as grand larcenists. It took Roman protection for sufficiently large resources to be mobilised by the cities for major developments in their public infrastructure, and the Lycians made the best of their circumstances, swallowed the payment of taxes and bribes to Roman officials, and they embraced Rome.

\section{Acknowledgements}

It is a pleasure to thank Martin Bachmann, deputy director of the Deutsches Archäologisches Institut, Abteilung Istanbul, for permitting me to join the team of archaeologists, philologists and ancient philosophers working at Oinoanda between 2008 and 2012, in a project which was funded by benefactors including the Gilbert de Botton Memorial Foundation, Martin Ferguson Smith, the Fritz Thyssen Stiftung, Gesellschaft der Freunde und Förderer der Nordrhein-Westfälischen Akademie der Wissenschaften, Kim Hee-Kyung Stiftung für europäische Kulturund Geisteswissenschaften, Franz-und-Eva-RutzenStiftung, Alumni/Freunde und Förderer der Universität zu Köln e.V. and the Stiftung Altertumskunde der Universität zu Köln. I was supported by a small personal research grant from the Hepburn Buckler Fund and the British Academy. Work on the non-philosophical inscriptions was a team-effort involving Gregor Staab and In-Yong Song, both of Cologne University, and myself. I am very glad to thank them for their collaboration. I am grateful also to Mustafa Barış Harmankaya and Nilgün Sentürk, who accompanied us at Oinoanda in 2011 and 2012 as the representatives of the Turkish Government, and to the Ministry of Culture and Tourism of the Republic of Turkey for granting permission for the work. I am much indebted for the comments and suggestions of the anonymous referees of this journal.

All figures are by the author, unless otherwise stated.

\section{References}

\section{Abbreviations}

$A E=$ L'Année épigraphique. Paris

$C I L=$ Mommsen, T. (ed.) 1863-: Corpus Inscriptionum Latinarum. Berlin, Berlin-Brandenburgische Akademie der Wissenschaften

I.Kaunos = Marek, C. 2006: Die Inschriften von Kaunos (Vestigia 55). Munich, Beck

I.Perge = Şahin, S. 1999: Die Inschriften von Perge I. Vorrömische Zeit, frühe und hohe Kaiserzeit (IK 54). Bonn, Habelt 
I.Side = Nollé, J. 1993: Side im Altertum : Geschichte und Zeugnisse (IK 43). Bonn, Habelt I.Stratonikeia = Şahin, M.Ç. 1981-1990: Die Inschriften von Stratonikeia (IK 21-22). Bonn, Habelt $I G=$ Inscriptiones Graecae. Berlin, de Gruyter 1873-

$I G R=$ Cagnat, R. 1901-1927: Inscriptiones Graecae ad res Romanas pertinentes. Paris, Leroux $I K=$ Engelmann, H. et al. 1972-: Inschriften griechischer Städte aus Kleinasien. Bonn, Habelt ILS = Dessau, H. 1892-1916: Inscriptiones Latinae selectae. Berlin, Weidmann LSJ = Liddell, H.G., Scott, R., Jones, H.S. 1940: A Greek-English Lexicon (9th edition). Oxford, Clarendon OGIS = Dittenberger, W. 1903 [1960]: Orientis Graecae Inscriptiones selectae. Leipzig [Hildesheim, Olms] SEG $=$ Hondius, J.J.E. et al. (eds) 1923-: Supplementum epigraphicum graecum. Leiden, Brill TAM = Kalinka, E. et al. 1901-: Tituli Asiae Minoris. Vienna, Österreichische Akademie der Wissenschaften

WS $($ Wiener Scheden) $=$ The archive of the Kleinasiatische Kommission of the Österreichische Akademie der Wissenschaften in Vienna, collected by R. Heberdey and E. Kalinka during their researches at Oinoanda in 1895 and 1902. For their published results, see Heberdey, R., Kalinka, E. 1897: Bericht über zwei Reisen im südwestlichen Kleinasien, ausgeführt im Auftrage der Kaiserlichen Akademie der Wissenschaften (Kaiserliche [Österreichische] Akademie der Wissenschaften, Philosophisch-Historische Klasse 45.1). Vienna, C. Gerold's Sohn

Adak, M., Wilson, M. 2012: 'Das Vespasiansmonument von Döşeme und die Gründung der Doppelprovinz Lycia et Pamphylia' Gephyra 9: 1-40

Balland, A. 1981: Fouilles de Xanthos 7. Inscriptions d'époque impériale du Létôon. Paris, Klincksieck

Barton, J., Muddiman, J. 2001: The Oxford Bible Commentary. Oxford, Oxford University Press

Behrwald, R. 2000: Der lykische Bund: Untersuchungen zu Geschichte und Verfassung (Antiquitas 1.48). Bonn, Habelt

Birley, A.R., Eck, W. 1993: 'M. Petronius Umbrinus, Legat von Cilicia, nicht von Lycia-Pamphylia' Epigraphica Anatolica 21: 45-54

Brandt, H. 1992: Gesellschaft und Wirtschaft Pamphyliens und Pisidiens im Altertum (Asia Minor Studien 7). Bonn, Habelt

Coulton, J.J. 1983: 'The buildings of Oinoanda' Proceedings of the Cambridge Philological Society 209: 1-17. http://dx.doi.org/10.1017/S0068673500004454

- 1986: 'Oinoanda: the agora' Anatolian Studies 36: 61-90. http://dx.doi.org/10.2307/3642827

- 1987: 'Roman aqueducts in Asia Minor' in S. Macready, F.H. Thompson (eds), Roman Architecture in the Greek World (Society of Antiquaries of London Occasional Papers n.s. 10). London, Society of Antiquaries of London: $72-84$

- 2012: The Balboura Survey and Settlement in Highland Southwest Anatolia (British Institute at Ankara Monograph 43). London, British Institute at Ankara

Daux, G. 1975: 'Note sur un decree Thessalien pour des juges étrangers' Zeitschrift für Papyrologie und Epigraphik 16: $37-38$

Deininger, J. 1965: Die Provinziallandtage der römischen Kaiserzeit (Vestigia 6). Munich, Beck

Delorme, J. 1960: Gymnasion: étude sur les monuments consacrés à l'éducation en Grèce (des origines à l'Empire Romain). Paris, de Boccard

Domingo Gygax, M. 2001: Untersuchungen zu den Lykischen Gemeinwesen in klassischer und hellenistischer Zeit (Antiquitas Reihe 1.49). Bonn, Habelt

Eck, W. 1970: 'Die Legaten von Lykien und Pamphylien unter Vespasian' Zeitschrift für Papyrologie und Epigraphik 6: $65-75$

- 1974: 'Neratius' Paulys Realencyclopädie der klassischen Altertumswissenschaft 14: 383-86

— 2000: 'Latein als Sprache politischer Kommunikation in Städten der östlichen Provinzen' Chiron 30: 641-60

- 2008: 'Die Bauinschrift der neronischen Thermen in Patara. Zur methodischen Auswertung einer partiell eradierten Inschrift' Zeitschrift für Papyrologie und Epigraphik 166: 269-75

Farrington, A. 1995: The Roman Baths of Lycia: An Architectural Study (British Institute of Archaeology at Ankara Monograph 20). London, British Institute of Archaeology at Ankara

Hall, A.S. 1984: 'An unidentified governor of Lycia-Pamphylia under Vespasian' Epigraphica Anatolica 4: 27-35

Hall, A.S., Milner, N.P. 1994: 'Education and athletics. Documents illustrating the festivals of Oinoanda' in D. French (ed.), Studies in the History and Topography of Lycia and Pisidia in Memoriam A.S. Hall (British Institute of Archaeology at Ankara Monograph 19). London, British Institute of Archaeology at Ankara: 1-47

Hallett, C.H. 2005: The Roman Nude. Heroic Portrait Statuary, 200 BC-AD 300. Oxford, Oxford University Press 
Hellmann, M.-C. 1992: Recherches sur le vocabulaire de l'architecture grecque, d'après les inscriptions de Délos. Paris, de Boccard

Hennig, D. 1995: 'Staatliche Ansprüche an privaten Immobilienbesitz in der klassischen und hellenistischen Polis' Chiron 25: 235-82

Horsley, G.H.R. 2007: The Greek and Latin Inscriptions in the Burdur Archaeological Museum (British Institute at Ankara Monograph 34). London, British Institute at Ankara

İplikçioğlu, B. 2006: 'Zwei Statthalter vespasianischer Zeit und die "Große” Therme in Inschriften von Olympos (Lykien)' Anzeiger der philosophisch-historischen Klasse der Österreichischen Akademie der Wissenschaften 141: $75-81$

- 2008: 'Die Provinz Lycia unter Galba und die Gründung der Doppelprovinz Lycia et Pamphylia unter Vespasian' Anzeiger der philosophisch-historischen Klasse der Österreichischen Akademie der Wissenschaften 143: 5-23

Işı1k, F., İşkan, H., Çevik, N. 1998/1999: 'Miliarium Lyciae' Lykia 4: 1-110

İşkan-Işı1k, H., Eck, W., Engelmann, H. 2008: 'Der Leuchtturm von Patara und Sex. Marcius Priscus als Statthalter der Provinz Lycia von Nero bis Vespasian' Zeitschrift für Papyrologie und Epigraphik 164: 91-121

Jones, A.H.M. 1940: The Greek City from Alexander to Justinian. Oxford, Clarendon

Jones, C.P. 2001: 'The Claudian monument at Patara' Zeitschrift für Papyrologie und Epigraphik 137: 161-68

- 2014: 'Epigraphica X. An inscription from Myra (Lycia)' Zeitschrift für Papyrologie und Epigraphik 188: 28-29

Kienast, D. 1996: Römische Kaisertabelle: Grundzüge einer römischen Kaiserchronologie. Darmstadt, Wissenschaftliche Buchgesellschaft

Kokkinia, C. 2004: 'Ruling, inducing, arguing: how to govern (and survive) a Greek province' in L. de Ligt, E.A. Hemelrijk, H.W. Singor (eds), Roman Rule and Civic Life: Local and Regional Perspectives. Amsterdam, J.C. Gieben: $39-57$

Kreiler, B. 1975: Die Statthalter Kleinasiens unter den Flaviern. PhD thesis, University of Munich

Lepke, A., Schuler, C., Zimmermann, K. 2015: 'Neue Inschriften aus Patara III. Elitenrepräsentation und Politik in Hellenismus und Kaiserzeit' Chiron 45: 291-384

Leschhorn, W. 1993: Antiken Ären (Historia Einzelschriften 81). Stuttgart, Steiner

Ling, R.J. 1981: 'Building Mk 1 at Oinoanda' Anatolian Studies 31: 31-53. http://dx.doi.org/10.2307/3642757

Macmullen, R. 1959: 'Roman imperial building in the provinces' Harvard Studies in Classical Philology 64: 207-35. http://dx.doi.org/10.2307/310942

Marksteiner, T., Wörrle, M. 2002: 'Ein Altar für Kaiser Claudius auf dem Bonda tepesi zwischen Myra und Limyra' Chiron 32: 545-69

Milner, N.P. 2012: 'The remaining inscriptions from the Balboura Survey Project' in J.J. Coulton, The Balboura Survey and Settlement in Highland Southwest Anatolia II (British Institute at Ankara Monograph 43). London, British Institute at Ankara: 83-127

- 2015: 'A new statue-base for Constantius II and the fourth-century imperial cult at Oinoanda' Anatolian Studies 65: 181-203. http://dx.doi.org/10.1017/S0066154615000101

Mitchell, S. 1987: 'Imperial building in the eastern Roman provinces' Harvard Studies in Classical Philology 91: 33365. http://dx.doi.org/10.2307/311413

- 1993: Anatolia. Land, Men, and Gods in Asia Minor. Oxford, Clarendon

Newton, H.C. 1902: The Epigraphical Evidence for the Reigns of Vespasian and Titus. PhD thesis, Cornell University Nielsen, I. 1990: Thermae et Balnea. Aarhus, Aarhus University Press

Orlandos, A.K., Travlos, I.N. 1986: Lexikon archaiōn architektonikōn horōn. Athens, Archaiologike Hetaireia

Pitt, R., 2014: 'Just as it has been written: inscribing building contracts at Lebadeia' in N. Papazarkadas (ed.), The Epigraphy and History of Boeotia: New Finds, New Prospects. Leiden/Boston, Brill

Reitzenstein, D. 2011: Die lykischen Bundespriester, Repräsentation der kaiserzeitlichen Elite Lykiens (Klio Beiträge zur Alten Geschichte, Beihefte neue Folge 17). Berlin, Akademie Verlag

— 2014: 'Neue Inschriften aus Tlos: Kronoskult, Agonistik und Euergetismus' Chiron 44: 551-613

Rhodes, P.J., Lewis, D.M. 1996: The Decrees of the Greek States. Oxford, Clarendon

Şahin, S., Adak, M. 2007: Stadiasmus patarensis : itinera romana provinciae Lyciae (Monographien zur Gephyra 1). Istanbul, Ege Yayınları

Sayar, M.H. 1992: 'Straßenbau in Kilikien unter den Flaviern nach einem neugefundenen Meilenstein' Epigraphica Anatolica 20: 57-61

Schazmann, P. 1923: Altertümer von Pergamon VI, Das Gymnasium. Berlin, de Gruyter 
Schuler, C., Zimmermann, K. 2012: 'Neue Inschriften aus Patara I. Zur Elite der Stadt in Hellenismus und früher Kaiserzeit' Chiron 42: 567-626

Smyth, H.W. 1956: Greek Grammar. Cambridge MA, Harvard University Press

Stenton, E.C., Coulton, J.J. 1986: 'Oinoanda: the water supply and aqueduct' Anatolian Studies 36: 15-59. http://dx.doi.org/10.2307/3642826

Syme, R. 1983: 'Domitian: the last years' Chiron 13: 121-46

Thornton, J. 2001: 'Pistoí symmachoi. Versioni locali e versione imperiale della provincializzazione della Licia' Mediterraneo Antico 4: 427-46

Torelli, M. 1968: 'The Cursus Honorum of M. Hirrius Fronto Neratius Pansa' Journal of Roman Studies 58: 170-75. http://dx.doi.org/10.2307/299705

Waelkens, M. (ed.) ca 2014: Sagalassos Visitor's Companion. Ağlasun, Municipality of Ağlasun

Waelkens, M., Poblome, J. (eds) 1995: Sagalassos III. Report on the Fourth Excavation Campaign of 1993. Leuven, Leuven University Press

Winter, B.W. 2003: Roman Wives, Roman Widows: The Appearance of New Women and the Pauline Communities. Grand Rapids, Eerdmans

Wörrle, M. 1988: Stadt und Fest im kaiserzeitlichen Kleinasien: Studien zu einer agonistischen Stiftung aus Oinoanda. Munich, Beck

Yegül, F. 1992: Baths and Bathing in Classical Antiquity. Cambridge MA, MIT Press 